UNIVERSIDADE ESTADUAL PAULISTA “JÚLIO DE MESQUITA FILHO” FACULDADE DE CIÊNCIAS AGRONÔMICAS CAMPUS DE BOTUCATU

\title{
ESPAÇAMENTO ENTRE FILEIRAS E POPULAÇÃO DE PLANTAS PARA CULTIVARES DE MAMONA DE PORTE BAIXO NA SAFRA DE VERÃO E SAFRINHA
}

GENIVALDO DAVID DE SOUZA-SCHLICK

Dissertação apresentada à Faculdade de Ciências Agronômicas da UNESP - Campus de Botucatu, para obtenção do título de Mestre em Agronomia (Agricultura).

BOTUCATU - SP

Janeiro -2010 
UNIVERSIDADE ESTADUAL PAULISTA “JÚLIO DE MESQUITA FILHO” FACULDADE DE CIÊNCIAS AGRONÔMICAS CAMPUS DE BOTUCATU

\title{
ESPAÇAMENTO ENTRE FILEIRAS E POPULAÇÃO DE PLANTAS PARA CULTIVARES DE MAMONA DE PORTE BAIXO NA SAFRA DE VERÃO E SAFRINHA
}

\section{GENIVALDO DAVID DE SOUZA-SCHLICK}

Engenheiro Agrônomo

\author{
Orientador: Prof. Dr. Rogério Peres Soratto
}

Dissertação apresentada à Faculdade de Ciências Agronômicas da UNESP - Campus de Botucatu, para obtenção do título de Mestre em Agronomia (Agricultura).

BOTUCATU - SP

Janeiro - 2010 
FICHA CATALOGRÁfICA ELABORAdA PELA SEÇÃo TÉCNICA DE AQUISIÇ̄̃o E TRATAMENTO DA INFORMAÇÃO - SERVIÇO TÉCNICO DE BIBLIOTECA E DOCUMENTAÇÃO - UNESP - FCA - LAGEADO - BOTUCATU (SP)

Souza-Schlick, Genivaldo David de, 1981Espaçamento entre fileiras e populaçăo de plantas para cultivares de mamona de porte baixo na safra de verão e safrinha / Genivaldo David de Souza-Schlick. - Botucatu : [s.n.], 2010 .

xv, $107 \mathrm{f}$. : tabs., gráfs., fots. color.

Dissertação (Mestrado) - Universidade Estadual Paulista, Faculdade de Ciências Agronômicas, Botucatu, 2010 Orientador: Rogério Peres Soratto Inclui bibliografia.

1. Mamona. 2. Ricinus communis L. 3. Arranjo espacial. 4. Produtividade de grăos. 5. Produtividade de óleos. 6. Densidade de plantas. I. Soratto, Rogério peres. II. Universidade Estadual Paulista "Júlio de Mesquita Filho" (Campus de Botucatu). Faculdade de Ciências Agronômicas. III. Título. 


\section{UNIVERSIDADE ESTADUAL PAULISTA "JÚLIO DE MESQUITA FILHO" FACULDADE DE CIÊNCIAS AGRONÔMICAS}

\section{CAMPUS DE BOTUCATU}

\section{CERTIFICADO DE APROVAÇĀO}

TITULO: "ESPAÇAMENTO ENTRE FLLEIRAS E POPULAÇÃO DE PLANTAS PARA CULTIVARES DE MAMONA DE PORTE BAIXO NA SAFRA DE VERÃO E SAFRINHA"

ALUNO: GENIVALDO DAVID DE SOUZA SCHLICK

ORIENTADOR: PROF. DR. ROGÉRIO PERES SORATTO

Aprovado pela Comissão Examinadora
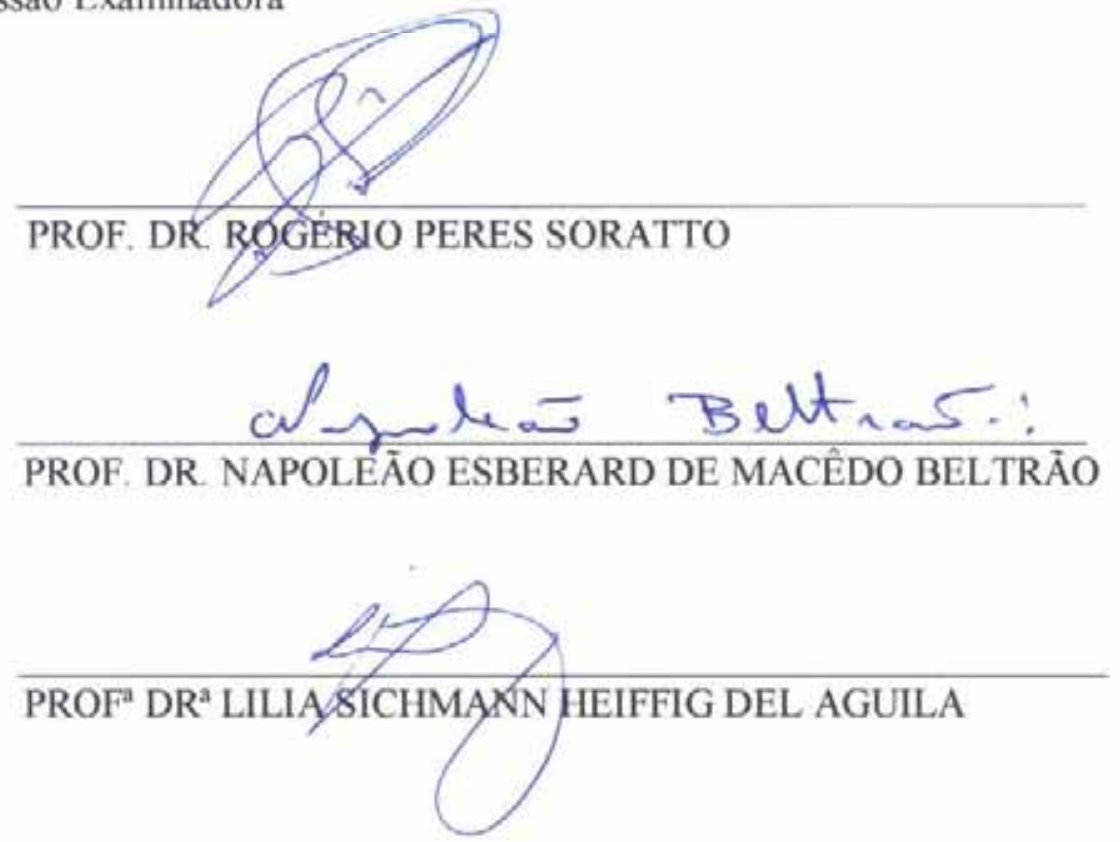

Data da Realização: 29 de janeiro de 2010. 


\title{
OFEREÇO
}

AO MEU SENHOR, JESUS CRISTO, POR ME AMAR E ME DAR A ALEGRIA DA SALVAÇÃO CONQUISTADA PELO SEU SACRIFÍCIO NA CRUZ.

\author{
MENSAGEM \\ "Nem olhos viram, nem ouvidos ouviram, nem jamais penetrou em coração \\ humano o que DEUS tem preparado para aqueles que o amam." \\ (1 Coríntios 2:9)
}

DEDICO

À MINHA MÃE EVA ALVES DE SOUZA À MINHA ESPOSA EUNICE C. SCHLICK SOUZA AOS MEUS IRMÃOS ADRIANA E ANDRÉ SOUZA E A TODOS DA MINHA FAMÍLIA SOUZA E SCHLICK 


\section{AGRADECIMENTOS}

A DEUS por se fazer presente em minha vida e por seu amor incondicional a mim e a toda a minha família.

À minha esposa Eunice que sempre me incentivou, me deu forças nos meus grandes desafios e ajudou na execução deste trabalho.

À minha mãe, por sempre interceder em oração por mim pela minha esposa e se abdicar de muitas coisas para nos ajudar a conquistar essa vitória.

Aos meus segundos pais Egon e Ema Schlick por sempre nos incentivarem e sonharem juntos conosco.

Aos meus irmãos Adriana e André, juntamente com os meus cunhados Jonas Azambuja e Ernani Schlick e minha cunhada Silvia Teixeira que sempre estiveram ao meu lado nessa caminhada, não medindo esforços para que esse sonho se tornasse uma realidade.

Ao Prof. Dr. Rogério Peres Soratto, pela brilhante orientação, pelos conselhos e pela oportunidade de compor sua equipe de trabalho. Não poderia deixar de dizer que, além de orientador, se tornou um dos meus maiores amigos.

À Fundação de Amparo à Pesquisa do Estado de São Paulo (FAPESP), pelo apoio financeiro, concedido por meio de bolsa de estudo e subvenção do trabalho de pesquisa.

Ao Prof. Dr. Carlos Alexandre Costa Crusciol que, com muita atenção, participou em todas as etapas, desde a elaboração até a conclusão, deste trabalho.

Ao Engenheiro Agrônomo, companheiro de turma e amigo para todas as horas, Adalton Mazetti Fernandes, que incansavelmente, trabalhou junto comigo, não somente nessa dissertação, mas também em outros projetos. 
Aos funcionários do Departamento de Produção Vegetal (Agricultura), pelo auxílio nos trabalhos, em especial aos funcionários de campo e a Dorival Pires de Arruda, Vera Lúcia Rossi, Ilanir Rosane R. Bocetto e Valéria Giandoni.

Aos estagiários(as) Bruno Mesquita San Giacomo, Douglas Bottino, Coralie Bussamra Pasquali e a todos outros alunos da FCA-UNESP e de outras instituições de ensino que auxiliaram na execução deste trabalho e pela amizade.

Ao Prof. Dr. Mauricio Dutra Zanotto, que contribuiu nas decisões técnicas e, pela concessão das sementes da cultivar de mamona FCA-PB.

Aos professores responsáveis pelas disciplinas cursadas: Maurício Dutra Zanotto (Seminários; Cultura e Melhoramento de Oleaginosas), aos professores João Domingos Rodrigues, Gisela Ferreira, Carmen S. F. Boaro e Elizabeth O. Ono (Fisiologia Vegetal; Fotossíntese e Produtividade Vegetal; Fisiologia do Desenvolvimento Vegetal; Metabolismo Mineral), Leonardo Theodoro Büll e Dirceu M. Fernandes (Fertilidade do Solo) e Hélio Grassi Filho (Nutrição Mineral de Plantas) por todo o ensinamento e sugestões para a vida acadêmica e profissional.

Aos pesquisadores (a) Prof. Dr. Luiz Roberto Colnago e Dra. Lucinéia Marconcini (EMBRAPA INSTRUMENTAÇÃO AGROPECUÁRIA/São Carlos-SP) pelo auxilio na realização das analises de teor de óleo nos grãos.

E amigos e irmãos em Cristo Jesus Vitória e Bruno, Lilis e João Roberto Quaiate e Luciene por sempre intercederem por nós em oração e, pela amizade.

A todos os colegas do curso de pós-graduação pelo companheirismo.

A todos que, direta ou indiretamente, contribuíram para a realização deste trabalho. 


\section{SUMÁRIO}

Página

LISTA DE TABELAS ….......................................................................... VIII

LISTA DE FIGURAS .................................................................................. XI

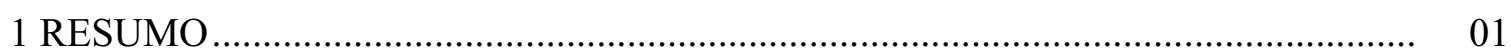

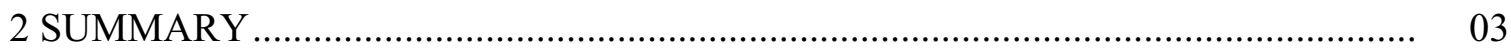

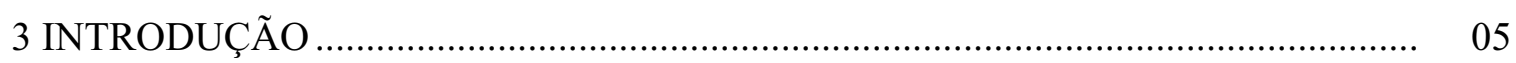

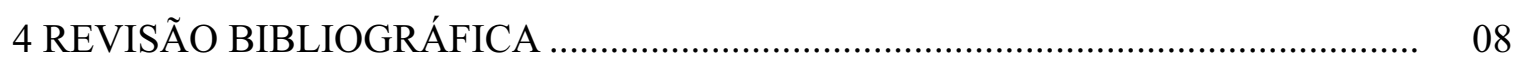

5 MATERIAL E MÉTODOS ............................................................................ 17

5.1 Localização e caracterização edafoclimática da área experimental....................... 17

5.2. Delineamento experimental e tratamentos ........................................................ 20

5.3 Caracterização das cultivares de mamona................................................................. 21

5.4 Condução dos experimentos em campo .............................................................. 21

5.4.1 Experimento da safra de verão (2007/08 e 2008/09) ..................................... 21

5.4.2 Experimento da safrinha (2008 e 2009) ........................................................... 23

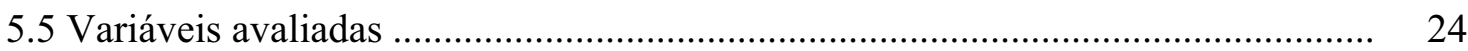

5.5.1 Matéria seca da parte aérea ...................................................................... 24

5.5.2. Diâmetro do caule ....................................................................................... 24

5.5.3 Altura de planta .................................................................................. 24

5.5.4 Altura de inserção do primeiro racemo ......................................................... 24

5.5.5 Componentes da produção ...................................................................... 24

5.5.6 Produtividade de grãos ........................................................................ 25

5.5.7 Teor de óleo no grão................................................................................... 25

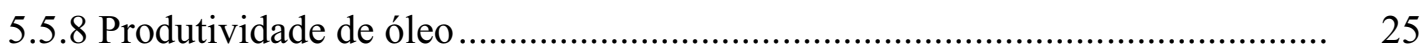

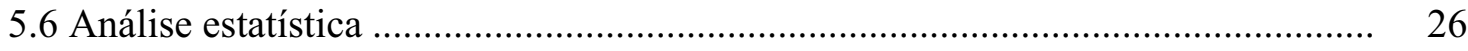

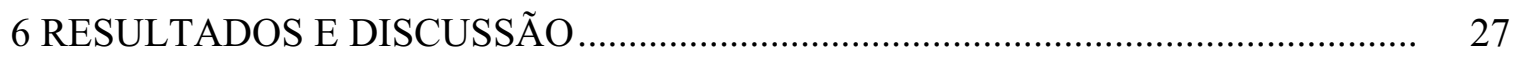

6.1 Experimento da Safra de verão (2007/2008 e 2008/2009) ...................................... 27

6.1.1 Cultivar FCA-PB ........................................................................................... 27

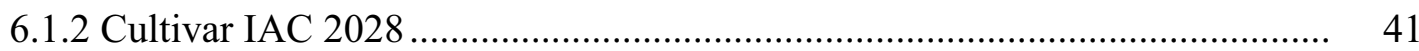

6.2 Experimento da safrinha (2008 e 2009) ........................................................ 58 


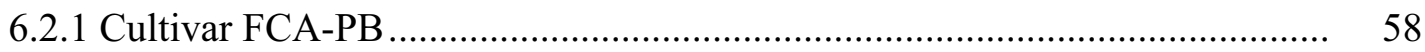

6.2.2 Cultivar IAC 2028 ...................................................................... 76

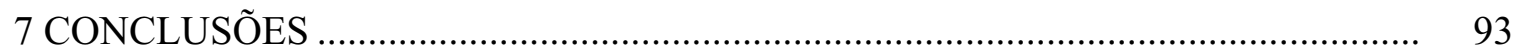

7.1 Experimento da safra de verão $(2007 / 2008$ e 2008/2009) .................................... 93

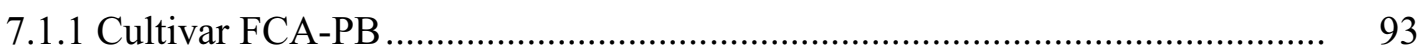

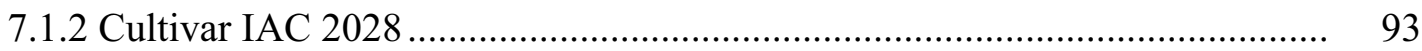

7.2 Experimento da safrinha (2008 e 2009) ......................................................... 94

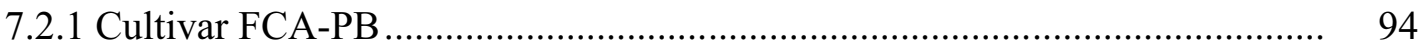

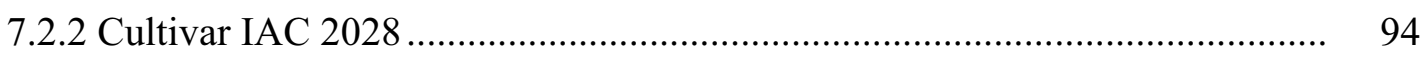

8 REFERÊNCIAS BIBLIOGRÁFICAS _............................................................... 95

9 APÊNDICE 


\section{LISTA DE TABELAS}

Página

Tabela 1. Atributos químicos do solo, na profundidade de 0 a $0,20 \mathrm{~m}$ antes da instalação dos experimentos.

Tabela 2. Distância entre plantas na fileira em função do espaçamento e da população de plantas.

Tabela 3. População final de plantas obtida na colheita da mamona cultivar FCAPB em função do espaçamento entre fileiras e da população inicial de plantas, nas safras de verão 2007/08 e 2008/09. Botucatu - SP

Tabela 4. Matéria seca da parte aérea e diâmetro do caule da cultivar de mamona FCA-PB, nas safras de verão 2007/08 e 2008/09, em função do espaçamento e população de plantas. Botucatu, SP.

Tabela 5. Altura de planta e de inserção do primeiro racemo da cultivar de mamona FCA-PB, nas safras de verão 2007/08 e 2008/09, em função do espaçamento e população de plantas. Botucatu, SP.

Tabela 6. Número de racemos por planta, frutos por racemo e grãos por fruto da cultivar de mamona FCA-PB, nas safras de verão 2007/08 e 2008/09, em função do espaçamento e população de plantas. Botucatu, SP

Tabela 7. Massa de 100 grãos e produtividade de grãos da cultivar de mamona FCA-PB, nas safras de verão 2007/08 e 2008/09, em função do espaçamento e população de plantas. Botucatu, SP.

Tabela 8. Teor de óleo no grão e produtividade de óleo da cultivar de mamona FCA-PB, nas safras de verão 2007/08 e 2008/09, em função do espaçamento e população de plantas. Botucatu, SP.

Tabela 9. População final de plantas obtida na colheita da mamona cultivar IAC 2028 em função do espaçamento entre fileiras e da população inicial de plantas, nas safras de verão 2007/08 e 2008/09. Botucatu - SP.

Tabela 10. Matéria seca da parte aérea e diâmetro do caule da cultivar de mamona IAC 2028, nas safras de verão 2007/08 e 2008/09, em função do espaçamento e população de plantas. Botucatu, SP.

Tabela 11. Altura da planta e de inserção do primeiro racemo da cultivar de mamona IAC 2028, nas safras de verão 2007/08 e 2008/09, em função do espaçamento e população de plantas. Botucatu, SP. 
Tabela 12. Número de racemos por planta, frutos por racemo e grãos por fruto da cultivar de mamona IAC 2028, nas safras de verão 2007/08 e 2008/09, em função do espaçamento e população de plantas. Botucatu, SP.

Tabela 13. Massa de 100 grãos e produtividade de grãos da cultivar de mamona IAC 2028, nas safras de verão 2007/08 e 2008/09, em função do espaçamento e população de plantas. Botucatu, SP.

Tabela 14. Teor de óleo no grão e produtividade de óleo da cultivar de mamona IAC 2028, nas safras de verão 2007/08 e 2008/09, em função do espaçamento e população de plantas. Botucatu, SP.

Tabela 15. População final de plantas obtida na colheita da mamona cultivar FCAPB em função do espaçamento entre fileiras e da população inicial de plantas, nas safrinhas 2008 e 2009. Botucatu - SP.

Tabela 16. Matéria seca da parte aérea e diâmetro do caule da cultivar de mamona FCA-PB, nas safrinhas 2008 e 2009, em função do espaçamento e população de plantas. Botucatu, SP.

Tabela 17. Altura da planta e de inserção do primeiro racemo da cultivar de mamona FCA-PB, nas safrinhas 2008 e 2009, em função do espaçamento e população de plantas. Botucatu, SP.

Tabela 18. Número de racemos por planta, frutos por racemo e grãos por fruto da cultivar de mamona FCA-PB, nas safrinhas 2008 e 2009, em função do espaçamento e população de plantas. Botucatu, SP.

Tabela 19. Massa de 100 grãos e produtividade de grãos da cultivar de mamona FCA-PB, nas safrinhas 2008 e 2009, em função do espaçamento e população de plantas. Botucatu, SP.

Tabela 20. Teor de óleo no grão e produtividade de óleo da cultivar de mamona FCA-PB, nas safrinhas 2008 e 2009, em função do espaçamento e população de plantas. Botucatu, SP.

Tabela 21. População final de plantas obtida na colheita da mamona cultivar IAC 2028 em função do espaçamento entre fileiras e da população inicial de plantas, nas safrinhas 2008 e 2009. Botucatu - SP.

Tabela 22. Matéria seca da parte aérea e diâmetro do caule da cultivar de mamona IAC 2028, nas safrinhas 2008 e 2009, em função do espaçamento e população de plantas. Botucatu, SP. 
Tabela 23. Altura da planta e de inserção do primeiro racemo da cultivar de mamona IAC 2028, nas safrinhas 2008 e 2009, em função do espaçamento e população de plantas. Botucatu, SP

Tabela 24. Número de racemos por planta, frutos por racemo e grãos por fruto da cultivar de mamona IAC 2028, nas safrinhas 2008 e 2009, em função do espaçamento e população de plantas. Botucatu, SP.

Tabela 25. Massa de 100 grãos de produtividade de grãos da cultivar de mamona IAC 2028, nas safrinhas 2008 e 2009, em função do espaçamento e população de plantas. Botucatu, SP.

Tabela 26. Teor de óleo no grão e produtividade de óleo da cultivar de mamona IAC 2028, nas safrinhas 2008 e 2009, em função do espaçamento e população de plantas. Botucatu, SP. 


\section{LISTA DE FIGURAS}

Página

Figura 1. Precipitação pluvial (I), temperatura máxima (_), temperatura mínima $(-)$, radiação solar $(-\times-)$ e umidade relativa do ar $(-\rightarrow)$ diárias registradas na área experimental de novembro de 2007 a setembro de 2008, bem como datas de emergência, florescimento e colheita das cultivares de mamona FCA-PB e IAC 2028, na safra de verão e safrinha.

Figura 2. Precipitação pluvial (I), temperatura máxima (_), temperatura mínima $(-)$, radiação solar $(-\times-)$ e umidade relativa do ar (- -$)$ diárias registradas na área experimental de novembro de 2008 a setembro de 2009, bem como datas de emergência, florescimento e colheita das cultivares de mamona FCA-PB e IAC 2028, na safra de verão e safrinha.

Figura 3. Matéria seca da parte aérea da cultivar de mamona FCA-PB em função da população de plantas, na média de quatro espaçamentos entre fileiras na safra de verão 2007/08 (A) e cada um dos quatro espaçamentos entre fileiras na safra de verão 2008/09 (B). * e ** são significativos a 5\% e $1 \%$ de probabilidade pelo teste $\mathrm{F}$, respectivamente.

Figura 4. Diâmetro do caule da cultivar de mamona FCA-PB em função da população de plantas nas safras de verão 2007/08 (A) e 2008/09 (B). ** é significativo a $1 \%$ de probabilidade pelo teste $\mathrm{F}$.

Figura 5. Altura de inserção do primeiro racemo da cultivar de mamona FCA-PB em função da população de plantas e do espaçamento entre fileiras na safra de verão $2008 / 09$. $* *$ é significativo a $1 \%$ de probabilidade pelo teste F.

Figura 6. Número de racemos por planta da cultivar de mamona FCA-PB em função da população de plantas, nas safras de verão 2007/08 (A) e 2008/09 (B). ** é significativos a 1\% de probabilidade pelo teste $\mathrm{F}$.

Figura 7. Número de frutos por racemo da cultivar de mamona FCA-PB em função da população de plantas, nas safras de verão 2007/08 (A) e $2008 / 09$ (B). $* *$ e * são significativo a $1 \%$ e $5 \%$ de probabilidade pelo teste $\mathrm{F}$, respectivamente.

Figura 8. Produtividade de grãos da cultivar de mamona FCA-PB em função da população de plantas, nas safras de verão 2007/08 (A) e 2008/09 (B). * e ** são significativos a $5 \%$ e $1 \%$ de probabilidade pelo teste $\mathrm{F}$, respectivamente. 
Figura 9. Produtividade de óleo da cultivar de mamona FCA-PB em função da população de plantas, nas safras de verão 2007/08 (A) e 2008/09 (B). ** é significativo a $1 \%$ de probabilidade pelo teste $\mathrm{F}$.

Figura 10. Matéria seca da parte aérea da cultivar de mamona IAC 2028 em função da população de plantas e do espaçamento entre fileiras nas safras de verão 2007/08 (A) e 2008/09 (B). ** é significativo a $1 \%$ de probabilidade pelo teste $\mathrm{F}$.

Figura 11. Diâmetro do caule da cultivar de mamona IAC 2028, em função da população de plantas nas safras de verão 2007/08 (A) e 2008/09 (B). ** é significativo a $1 \%$ de probabilidade pelo teste $\mathrm{F}$.

Figura 12. Altura da planta da cultivar de mamona IAC 2028, em função da população de plantas na safra de verão $2007 / 08$. ** é significativo a $1 \%$ de probabilidade pelo teste $\mathrm{F}$.

Figura 13. Altura de inserção do primeiro racemo da cultivar de mamona IAC 2028 , em função da população de plantas na safra de verão $2007 / 08$. ** é significativo a $1 \%$ de probabilidade pelo teste $\mathrm{F}$.

Figura 14. Número de racemos por planta da cultivar de mamona IAC 2028 em função da população de plantas, na média de quatro espaçamentos entre fileiras na safra de verão 2007/08 (A) e cada um dos quatro espaçamentos entre fileiras na safra de verão 2008/09 (B). ** é significativo a $1 \%$ de probabilidade pelo teste $\mathrm{F}$.

Figura 15. Número de frutos por racemo da cultivar de mamona IAC 2028, em função da população de plantas nas safras de verão 2007/08 (A) e 2008/09 (B). ** é significativo a 1\% de probabilidade pelo teste $\mathrm{F}$.

Figura 16. Massa de 100 grãos da cultivar de mamona IAC 2028, em função da população de plantas nas safras de verão 2007/08 (A) e 2008/09 (B). * e ** são significativos a $5 \%$ e $1 \%$ de probabilidade pelo teste $\mathrm{F}$, respectivamente..

Figura 17. Produtividade de grãos da cultivar de mamona IAC 2028 em função da população de plantas, na média de quatro espaçamentos entre fileiras na safra de verão 2007/08 (A) e cada um dos quatro espaçamentos entre fileiras na safra de verão 2008/09 (B). * e ** são significativos a 5\% e $1 \%$ de probabilidade pelo teste $\mathrm{F}$, respectivamente. 
Figura 18. Produtividade de óleo da cultivar de mamona IAC 2028 em função da população de plantas, na média de quatro espaçamentos entre fileiras na safra de verão 2007/08 (A) e cada um dos quatro espaçamentos entre fileiras na safra de verão 2008/09 (B). ** é significativo e $1 \%$ de probabilidade pelo teste $\mathrm{F}$.

Figura 19. Matéria seca da parte aérea da cultivar de mamona FCA-PB em função dos quatro espaçamentos entre fileiras na safrinha 2008 (A) e da população de plantas, na média de quatro espaçamentos entre fileiras na safrinha 2009 (B). ** é significativo a 1\% de probabilidade pelo teste $\mathrm{F}$.

Figura 20. Diâmetro do caule da cultivar de mamona FCA-PB em função da população de plantas e do espaçamento entre fileiras nas safrinhas 2008 (A) e 2009 (B). * e ** são significativos a 5\% e 1\% de probabilidade pelo teste $\mathrm{F}$, respectivamente.

Figura 21. Altura de plantas da cultivar de mamona FCA-PB em função da população de plantas e do espaçamento entre fileiras nas safrinhas 2008 (A) e 2009 (B). ** é significativo a $1 \%$ de probabilidade pelo teste $\mathrm{F}$.

Figura 22. Altura de inserção do primeiro racemo da cultivar de mamona FCA-PB em função dos quatro espaçamentos entre fileiras na safrinha 2008 (A) e da população de plantas, na média de quatro espaçamentos entre fileiras na safrinha 2009 (B). * e ** são significativos a $5 \%$ e $1 \%$ de probabilidade pelo teste $\mathrm{F}$, respectivamente.

Figura 23. Número de racemos por planta da cultivar de mamona FCA-PB em função da população de plantas e do espaçamento entre fileiras nas safrinhas 2008 (A) e 2009 (B). ** é significativo a 1\% de probabilidade pelo teste $\mathrm{F}$.

Figura 24. Número de frutos por racemo da cultivar de mamona FCA-PB em função da população de plantas, na média de quatro espaçamentos entre fileiras na safrinha 2008 (A) e cada um dos quatro espaçamentos entre fileiras na safrinha 2009 (B). ** é significativo a 1\% de probabilidade pelo teste $\mathrm{F}$

Figura 25. Número de grãos por fruto da cultivar de mamona FCA-PB em função da população de plantas e do espaçamento entre fileiras na safrinha 2008. ** é significativos a $1 \%$ de probabilidade pelo teste $\mathrm{F}$.

Figura 26. Massa de 100 grãos da cultivar de mamona FCA-PB em função da população de plantas na safrinha 2008 . * é significativo a $5 \%$ de probabilidade pelo teste $\mathrm{F}$. 
Figura 27. Produtividade de grãos da cultivar de mamona FCA-PB em função da população de plantas e do espaçamento entre fileiras nas safrinhas 2008 (A) e 2009 (B). * e ** são significativos a 5\% e $1 \%$ de probabilidade pelo teste $\mathrm{F}$, respectivamente.

Figura 28. Produtividade de óleo da cultivar de mamona FCA-PB em função da população de plantas e do espaçamento entre fileiras nas safrinhas 2008 (A) e 2009 (B). * e ** são significativos a 5\% e 1\% de probabilidade pelo teste $\mathrm{F}$, respectivamente.

Figura 29. Matéria seca da parte aérea da cultivar de mamona IAC 2028 em função da população de plantas nas safrinhas 2008 (A) e 2009 (B). ** é significativo a $1 \%$ de probabilidade pelo teste $\mathrm{F}$.

Figura 30. Diâmetro do caule da cultivar de mamona IAC 2028 em função da população de plantas, na média de quatro espaçamentos entre fileiras na safrinha 2008 (A) e cada um dos quatro espaçamentos entre fileiras na safrinha 2009 (B). ** é significativo a 1\% de probabilidade pelo teste $\mathrm{F}$.

Figura 31. Altura de plantas da cultivar de mamona IAC 2028 em função da população de plantas, na média de quatro espaçamentos entre fileiras na safrinha 2008 (A) e cada um dos quatro espaçamentos entre fileiras na safrinha 2009 (B). ** é significativo a 1\% de probabilidade pelo teste $\mathrm{F}$.

Figura 32. Altura de inserção do primeiro racemo da cultivar de mamona IAC 2028 em função da população de plantas nas safrinhas 2008 (A) e 2009 (B). ** é significativo a $1 \%$ de probabilidade pelo teste $\mathrm{F}$.

Figura 33. Número de racemos por planta da cultivar de mamona IAC $2028 \mathrm{em}$ função da população de plantas, na média de quatro espaçamentos entre fileiras na safrinha 2008 (A) e cada um dos quatro espaçamentos entre fileiras na safrinha 2009 (B). ${ }^{* *}$ é significativo a $1 \%$ de probabilidade pelo teste $\mathrm{F}$

Figura 34. Número de frutos por racemo da cultivar de mamona IAC $2028 \mathrm{em}$ função da população de plantas e do espaçamento entre fileiras nas safrinhas 2008 (A) e 2009 (B). ** é significativo a 1\% de probabilidade pelo teste $\mathrm{F}$

Figura 35. Massa de 100 grãos da cultivar de mamona IAC 2028 em função da população de plantas nas safrinhas 2008 (A) e 2009 (B). ** é significativo a $1 \%$ de probabilidade pelo teste $\mathrm{F}$. 
Figura 36. Produtividade de grãos da cultivar de mamona IAC 2028 em função da população de plantas e do espaçamento entre fileiras nas safrinhas 2008 (A) e 2009 (B). * e ** são significativos a 5\% e 1\% de probabilidade pelo teste $\mathrm{F}$, respectivamente.

Figura 37. Produtividade de óleo da cultivar de mamona IAC 2028 em função da população de plantas e do espaçamento entre fileiras nas safrinhas 2008 (A) e 2009 (B). * e ** são significativos a 5\% e 1\% de probabilidade pelo teste $\mathrm{F}$, respectivamente. 


\section{RESUMO}

Com o lançamento de novas cultivares de mamona de porte baixo e frutos indeiscentes, adequados para o cultivo em grandes áreas e colheita mecanizada, fez-se necessário estabelecer quais os melhores espaçamentos e populações de plantas, para que cada um desses materiais possa atingir a máxima produtividade. Nesse sentido, objetivou-se com o presente trabalho avaliar a influência do espaçamento entre fileiras e da população de plantas no crescimento e produtividade de cultivares de mamona de porte baixo na safra de verão (novembro) e em safrinha (março). Para tanto, foram realizados quatro experimentos, com dois cultivares (FCA-PB e IAC 2028), em duas épocas de cultivo (safra de verão e safrinha), conduzidos durante os anos agrícolas 2007/08 e 2008/09. O delineamento experimental utilizado em todos os experimentos foi o de blocos casualizados, em esquema de parcelas subdivididas, com quatro repetições. As parcelas foram constituídas por quatro espaçamentos entre fileiras $(0,45,0,60,0,75$ e $0,90 \mathrm{~m})$ e as subparcelas por quatro populações iniciais de plantas $\left(25.000,40.000,55.000\right.$ e 70.000 plantas $\left.\mathrm{ha}^{-1}\right)$. O trabalho de pesquisa foi conduzido em condições de campo, na Fazenda Experimental Lageado da Faculdade de Ciências Agronômicas - UNESP, campus de Botucatu, SP. Na safra de verão foi possível observar que: para a cultivar FCA-PB, o aumento da população de plantas, independente do espaçamento entre fileiras, diminuiu a população final de plantas, a matéria seca da parte aérea, o número de racemos por planta e de frutos por racemo; o aumento da população de plantas nos espaçamentos de 0,60 e $0,75 \mathrm{~m}$ entre fileiras aumentou a altura de inserção do primeiro racemo; a maior produtividade de grãos e de óleo da mamoneira FCA-PB foi obtida com 
população inicial entre 55.000 e 70.000 plantas ha ${ }^{-1}$, utilizando-se o espaçamento de 0,45 ou 0,60 m entre fileiras. Na cultivar IAC 2028, o aumento da população de plantas diminuiu a população final de plantas, a matéria seca da parte aérea, o diâmetro do caule, número de racemos por planta, número de frutos por racemo, massa de 100 grãos e aumentou a altura das plantas e a altura de inserção do primeiro racemo, independentemente do espaçamento utilizado; em menores espaçamentos entre fileiras e menores populações de plantas, a mamoneira produziu maior número de racemos por planta e menor número de grãos por fruto; o melhor arranjo de plantas, proporcionado pelos menores espaçamentos entre fileiras, proporcionou as maiores produtividades de grãos e de óleo; a população de plantas, independentemente do espaçamento entre fileiras, teve pouco efeito na produtividade de grãos e óleo. Na safrinha observou-se que: para a cultivar FCA-PB, o maior espaçamento entre fileiras $(0,90 \mathrm{~m})$ proporcionou menor crescimento das plantas e produtividade de grãos e óleo; as maiores produtividade de grãos e de óleo foram obtidas com o espaçamento de $0,75 \mathrm{~m}$ entre fileiras e populações intermediárias. Na cultivar IAC 2028, os maiores espaçamentos entre fileiras proporcionaram o menor crescimento das plantas, número de racemos por planta, número de frutos por racemo, produtividade de grãos e produtividade de óleo; as maiores populações de plantas proporcionaram menores valores de matéria seca da parte aérea, diâmetro do caule, componentes da produção e, maiores altura de inserção do primeiro racemo; o espaçamento entre fileiras de $0,60 \mathrm{~m}$ proporcionou as maiores produtividade de grãos, independentemente da população de plantas. 


\section{ROW SPACING AND PLANT POPULATION FOR DWARF CASTOR BEAN}

CULTIVARS IN SUMMER AND OUT-OF-SEASON CROPPING. Botucatu, 2010 107p.

Dissertação (Mestrado em Agronomia/Agricultura) - Faculdade de Ciências Agronômicas, Universidade Estadual Paulista.

Author: GENIVALDO DAVID DE SOUZA-SCHLICK

Adviser: ROGÉRIO PERES SORATTO

\section{SUMMARY}

The release of new dwarf castor bean cultivars and indehiscent fruit is suitable for growth in large scale with and mechanized harvest, therefore there is a need to establish which row spacing and plant population is the best for each of these materials can achieve the maximum yield. In this sense, the objective of this study was to evaluate the influence of the row spacing and plant population in the growth and yield of dwarf castor bean cultivars in the summer (November) and out-of-season (March) cropping. Therefore, four experiments were performed, i.e., two cultivars (FCA-PB e IAC 2028) in two cropping seasons (summer and out-of-season), conducted during 2007/08 and 2008/09 agricultural years. The experiment was arranged in a randomized block design with split-plot and four replications. Plots comprised four row spacings $(0.45,0.60,0.75$, and $0.90 \mathrm{~m})$, and subplots comprised four initial plant populations $(25,000,40,000,55,000$, and 70,000 plants per hectare). In summer cropping season was observed: in the FCA-PB cultivar, plant population increasing, regardless of row spacing, decreased final plant population, aboveground dry matter, stem diameter, racemes per plant and fruits per raceme; the plant population increasing, at 0.60 and $0.75 \mathrm{~m}$ row spacings, increased the height of the first raceme insertion; the highest grain and oil yields were obtained with a population among 55,000 and 70,000 plants per hectare and 0.45 or $0.60 \mathrm{~m}$ row spacings. In the IAC 2028 cultivar, the plant population increasing, decreased final plant population, aboveground dry matter, stem diameter, number of racemes per plant, number of fruits per raceme, mass of 100 grains and increased plant height and height of the first raceme insertion, regardless of the row spacing 
used. In smaller row spacings and lower plant populations, castor bean produced higher number of racemes per plant and lower number of grains per fruit; better plant arrangement, promoted by lower row spacings, provided higher grain and oil yields; plant population, regardless of row spacing, had little effect on grain and oil yields. In out-of-season was observed: for FCA-PB cultivar, the biggest row spacing $(0.90 \mathrm{~m})$, provided lower plant growth and grain and oil yields; the largest grain and oil yields was obtained with intermediate row spacings and plant populations. In IAC 2028 cultivar, the largest row spacing provided the lower plants growth, number of racemes per plant, number of fruits per raceme, grain and oil yields; the highest plant populations provided smaller aboveground dry matter, stem diameter, yield components, and higher height of the first raceme insertion; the row spacing $0.60 \mathrm{~m}$ provided the highest grain yield, regardless of the plant population used.

Keywords: Ricinus communis L., spatial arrangement, plant density, grain yield, oil yield. 


\section{INTRODUÇÃ̃O}

A demanda industrial por óleos vegetais cresce a cada ano, e o interesse mundial pelos oleoquímicos está em alta, haja vista a sua diversificada forma de aplicações.

A mamona (Ricinus communis L.) é um arbusto de cujo fruto se extrai um óleo de excelentes propriedades, de largo uso como insumo industrial, devido ao fato de que, em muitas de suas aplicações, não se pode substituí-lo por outros óleos vegetais.

O Brasil já foi o maior produtor mundial e exportador de óleo de mamona. O Estado de São Paulo, na década de 70, era o principal produtor nacional. A partir da década de 80, o Brasil perdeu competitividade, com a entrada da Índia e da China no mercado internacional de produtores e exportadores de óleo. Verificou-se, inclusive no ano de 2004, que as importações superaram as exportações de óleo de mamona, uma vez que a produção nacional não foi capaz de suprir a demanda. A perda da participação se deve principalmente ao alto custo de produção associado à falta de uso de tecnologia, como insumos, sementes melhoradas, colheita mecanizada, organização dos produtores e outros fatores.

Recentemente, a ricinocultura tem reconquistado espaço econômico, político e ambiental no Brasil devido ao interesse pela indústria ricinoquímica e pela busca de novas fontes de energias renováveis, visto que obtenção de diesel a partir do petróleo tem custo elevado, suas reservas são esgotáveis, além da queima deste combustível ser altamente poluente. De acordo com a literatura, o biodiesel é uma das alternativas viáveis a substituir 
combustíveis obtidos do petróleo. Assim, a mamona vem ganhando espaço em todo o território nacional, principalmente nos estados do Nordeste e Centro-Oeste. O biodiesel obtido a partir do óleo da mamona apresenta qualidade muito superior às demais fontes oleaginosas, além do excelente rendimento na obtenção, um litro de óleo da cultura origina um litro de biodiesel. Estas características da mamona são responsáveis pelo incentivo que a cultura tem recebido de órgãos federais, por meio das entidades de fomento e de pesquisa, e privados, por meio das indústrias.

A produção da mamona no Brasil é realizada basicamente de duas formas. Na primeira, chamada tradicional, são utilizados cultivares de porte médio e alto e colheita manual, sendo importante, principalmente para pequenos produtores. Porém, no final da década de noventa, com a ampliação da demanda devido à utilização industrial do óleo de mamona, começou uma segunda forma de cultivo, principalmente nas regiões de MG e MT, que tem necessidade de uso de tecnologias modernas para o cultivo em grandes áreas. Para isso foram e estão sendo desenvolvidos cultivares de porte baixo, adequados para colheita mecanizada, amadurecimento uniforme dos frutos e indeiscência facilitando a adoção da cultura por produtores de médio e grande porte.

Com o avanço do melhoramento genético da mamoneira seu cultivo será economicamente viável em médias e grandes propriedades, porém o cultivo em grande escala exige tecnologias mais avançadas para que as novas cultivares expressem seu potencial produtivo. Como é recente o cultivo da mamoneira em grandes áreas, tem-se uma carência muito grande de práticas de cultivo.

Entre as técnicas culturais que afetam a produtividade da oleaginosa, está o espaçamento entre fileiras e a população de plantas. Existe um número ideal de plantas que possibilita a obtenção da produtividade máxima. Um número de plantas abaixo do ideal pode favorecer o desenvolvimento de plantas daninhas. $\mathrm{O}$ aumento da população de plantas provoca competição por nutrientes, água, luz e $\mathrm{CO}_{2}$, resultando em decréscimo de produção por planta. Já, uma população excessiva de plantas acarreta rápido esgotamento das reservas de água do solo por evapotranspiração e causa o auto-sombreamento. Além disso, como, normalmente, existe diferença na disponibilidade de recursos ambientais no período de safra e safrinha, especialmente luz e água, o espaçamento e a população de plantas ideal podem não ser os mesmos para ambas as safras. 
Diante do exposto, objetivou-se com o presente trabalho avaliar a influência do espaçamento entre fileiras e da população de plantas no crescimento e produtividade de cultivares de mamona de porte baixo na safra de verão (novembro) e em safrinha (março). 


\section{REVISÃO BIBLIOGRÁFICA}

A mamoneira pertence à família Euphorbiaceae, que possui cerca de 7.000 espécies, apresentando grande variação fenotípica, com variação de porte, coloração do caule, folhas, inflorescências, tipos de cachos (tamanho, formato, com e sem acúleos, etc.) e outros aspectos morfológicos (BELTRÃO; AZEVEDO, 2007).

A mamoneira é originária do continente africano, possivelmente da Etiopia e apresenta seis subespécies e 25 variedades botânicas, além de dezenas de cultivares e híbridos comerciais em todo o mundo (SAVY FILHO et al., 1999).

É uma planta de clima tropical equatorial (HERMELY, 1981), com relativa adaptabilidade ambiental as regiões subtropicais, sendo explorada comercialmente entre as latitudes $52^{\circ} \mathrm{N}$ e $40^{\circ} \mathrm{S}$ (WEISS, 1983). Apesar de sua rusticidade, não tolera a salinidade nem a sodicidade do solo, necessitando de aproximadamente $900 \mathrm{~mm}$ de chuva/ciclo para alcançar altas produtividades.

De acordo com Amorim Neto et al. (2001), a cultura necessita de altitude de pelo menos $300 \mathrm{~m}$ e seu ótimo ecológico é de $650 \mathrm{~m}$ de altitude, com temperatura media do ar em torno de $25{ }^{\circ} \mathrm{C}$, variando entre 20 e $30{ }^{\circ} \mathrm{C}$. Tem metabolismo fotossintético $\mathrm{C}_{3}$, menos eficiente quando comparado ao $\mathrm{C}_{4}\left(\mathrm{D}^{\prime} \mathrm{YAKOV}, 1986\right)$, porém pode produzir enorme quantidade de biomassa vegetal.

Essa oleaginosa é uma espécie predominantemente autógama, porém com alta taxa de alogamia (TÁVORA, 1982), podendo chegar a 40\% de taxa de cruzamento (MOREIRA et al., 1996; BELTRÃO; AZEVEDO, 2007). A maioria das plantas apresenta 
frutos deiscentes, mas atualmente existe disponível no mercado materiais indeiscentes de grande importância ao produtor, pois permitem apenas uma colheita manual, favorecendo, principalmente, à colheita mecanizada.

Botanicamente, o florescimento da mamoneira é denominado de simpodial, pois o ramo principal se desenvolve em posição vertical até a emissão da primeira inflorescência terminal. Com o surgimento do racemo, algumas gemas situadas nos nós imediatamente abaixo são ativadas dando origem a ramos laterais (BELTRÃO et al., 2007a). Desta maneira, o aparecimento da inflorescência da-se sequencialmente, com determinado intervalo entre a emissão das inflorescências primárias e secundárias, secundarias e terciárias, assim sucessivamente (SAVY FILHO, 2005).

A mamoneira e uma planta normalmente monóica. Flores unissexuais masculinas e femininas ocorrem numa mesma planta, numa mesma inflorescência, em torno de um eixo principal (raquis). Em geral as flores femininas constituem de 30 a $50 \%$ e as masculinas de 50 a 70\%. Essa relação pode ser alterada por fatores genéticos e não genéticos, o déficit hídrico ou temperatura muito alta (estresse) podem induzir a formação de maior número de flores masculinas (SAVY FILHO, 2005).

Moshkin (1986) relata que esta espécie, que tem a particularidade de emitir as flores masculinas na parte inferior da inflorescência e as femininas na parte superior, diferentemente das demais espécies, apresenta crescimento não uniforme no tocante ao amadurecimento, pois cada cacho tem sua idade e independe do outro, e a planta tem crescimento do tipo indeterminado, com varias fases (estádios) de desenvolvimento, tais como: germinação, formação da estrutura vegetativa, formação do racemo principal ou de primeira ordem, floração e amadurecimento das sementes, de cada racemo, iniciando-se pelo central ou principal e assim por diante, somente paralisando o surgimento de racemos novos pela seca, caso do Nordeste do Brasil ou pelo frio, caso da Rússia (BELTRÃO et al. 2007b).

A mamona possui um sistema radicular pivotante, podendo atingir uma profundidade de 3 metros. As raízes laterais projetam sistema radicular de 1,25 metros de extensão. A mamoneira apresenta caule fistuloso com coloração variando do verde ao roxo, com nos salientes, bem visíveis e destacados. Apresenta folhas de 5 a 11 lóbulos, com margens serradas ou dentadas. Possuem pecíolo longo e fistuloso, com glândulas nectaríferas. 
O limbo apresenta coloração acompanhando a do caule, variando de verde ao roxo, com nervuras proeminentes na superfície inferior (BELTRÃO; AZEVEDO, 2007).

De acordo com Moshkin e Perestova (1986), a mamona possui um lento crescimento inicial, com o processo de germinação ocorrendo entre oito a vinte dias dependendo do vigor das sementes e das condições do ambiente onde as sementes foram colocadas para germinarem, sendo que a temperatura limitante para este processo é de $14^{\circ} \mathrm{C}$, com o máximo de $36^{\circ} \mathrm{C}$ e ótimo de $31^{\circ} \mathrm{C}$, e a umidade limite para inicio do processo é de $32 \%$ de água com relação ao peso da semente.

Em geral, a mamoneira apresenta um ciclo de 180 a 240 dias, recomendando-se seu plantio no inicio da estação chuvosa. As sementes apresentam-se com diferentes tamanhos, formatos e grande variabilidade de coloração, contendo um teor de óleo entre 45-50\% (SAVY FILHO, 2005).

O cultivo dessa oleaginosa no Brasil realiza-se basicamente de duas formas. Tradicional, utilizada por pequenos agricultores. Neste sistema de cultivo a colheita é manual e os cultivares utilizados são de porte médio a alto. Porém, no final da década de noventa do século passado, com a ampliação da demanda devido à utilização industrial do óleo de mamona pela indústria ricinoquímica, começou uma segunda forma de cultivo, principalmente nas regiões de MG e MT. Este novo sistema de cultivo é destinado a grandes áreas e, conseqüentemente, com níveis tecnológicos mais avançados.

O óleo de mamona tem inúmeras aplicações, como a fabricação de cosméticos, perfumaria e de muitos tipos de drogas farmacêuticas, corantes, anilinas, desinfetantes, germicidas, óleos lubrificantes para uso em condições de temperaturas extremas, colas e aderentes, base para fungicidas e inseticidas, tintas de impressão e vernizes, autoblocantes para fibras óticas, na elaboração de próteses, e implantes na substituição do silicone em cirurgias ósseas, de mama e de próstata, como aditivos do querosene em tanques de aviões e foguetes (CHIERICE; CLARO NETO, 2001).

Todavia, a ascensão da mamona não se limitou à indústria ricinoquímica. A crescente demanda de fontes alternativas de energia impulsionou a produção de biodiesel. O biodiesel pode ser feito a partir de qualquer óleo vegetal, ou mesmo gordura animal (HOLANDA, 2004). Porém, o óleo da mamoneira destaca-se por ser mais denso e viscoso de todos, sendo, onze vezes mais denso que o óleo da soja. É o único óleo glicerídico 
solúvel em álcool a frio, enquanto que os demais óleos necessitam serem aquecidos até $70^{\circ} \mathrm{C}$ para atingirem solubilidade. Ainda apresenta cerca de $4 \%$ a mais de oxigênio, o que é altamente desejável. Além disso, o rendimento com óleo da mamona é muito elevado, visto que um litro de óleo possibilita a obtenção de um litro de biodiesel (BELTRÃO, 2003).

Em função da relevância que a mamona apresenta para produção de óleo para uso industrial e biodiesel e o incentivo de seu cultivo em praticamente todo o país, a área de melhoramento genético tem contribuído, buscando lançar cultivares com as seguintes características: elevado potencial produtivo, precocidade, amadurecimento uniforme, baixa deiscência, alto teor de óleo, resistência a pragas e doenças e porte baixo que são adequados à colheita mecanizada, tornando a cultura economicamente viável a médias e grandes propriedades (FREIRE et al., 2001).

Com o lançamento de cultivares e híbridos adaptados à colheita mecanizada, a ricinocultura tornou-se economicamente viável em médias e grandes propriedades, porém o cultivo em grande escala exige tecnologias mais avançadas para que esses materiais expressem seu potencial produtivo.

O Brasil já ocupou lugar de destaque na produção mundial de mamona, porém, perdeu sua competitividade (SANTOS et al., 2004). Isto se explica em razão dos produtores brasileiros não utilizarem melhores níveis tecnológicos, principalmente em termos de uso de insumos industriais, como fertilizantes, sementes melhoradas ou mesmo melhores sistemas de cultivo, semeadura e colheita (SAVY FILHO et al., 1999).

Segundo Azevedo et al. (1997; 2007), o atraso no avanço tecnológico do cultivo da oleaginosa e, consequentemente baixas produtividades justifica-se por sua exploração, até hoje, ter sido típica de pequenas propriedades, sendo cultivada sob baixo a médio nível tecnológico, com pouco ou nenhum uso de fertilizantes e corretivos.

No Brasil, a produtividade média está ao redor de $760 \mathrm{~kg} \mathrm{ha}^{-1}$, nível de produção considerado muito baixo (CONAB, 2009). Mas, segundo Savy Filho e Banzatto (1990), lavouras tecnificadas no Estado de São Paulo podem alcançar produtividades de 1.500 $\mathrm{kg} \mathrm{ha}^{-1}$ a $4.000 \mathrm{~kg} \mathrm{ha}^{-1}$.

Assim, para que o Brasil retome o posto de destaque na produção mundial de mamona, faz-se necessário determinar para as novas cultivares, lançadas pelo melhoramento, quais as práticas culturais mais adequadas para que sejam obtidas altas 
produtividades, facilitando os tratos culturais e as operações mecanizadas, envolvendo a colheita. Assim, o desenvolvimento de tecnologias que viabilizem a ricinocultura, tanto na safra de verão quanto na safrinha, é de suma importância.

Para obtenção de altas produtividades de grãos, deve-se maximizar a duração da interceptação da radiação, utilizar eficientemente a energia interceptada (fotossíntese), distribuir os novos assimilados na proporção ótima para formação de folhas, caules, raízes e de estruturas reprodutivas e manter estes processos com custo mínimo para a planta (LOOMIS; AMTHOR, 1999). Tais processos são bastante complexos, tornando muito difícil a maximização simultânea do uso destes fatores (ARGENTA et al., 2001).

A influência dos fatores limitantes da produtividade de uma cultura pode ser melhor compreendida se o potencial máximo de sua produtividade for conhecido. Além de fatores genéticos, a produtividade de uma cultura depende das condições de solo, clima e particularmente da radiação solar (MELGES et al., 1989). A utilização de luz é o processo mais importante para a produtividade, porque é através da fotossíntese que a planta acumula matéria orgânica em seus tecidos. A quantidade de energia convertida e, portanto, a quantidade de biomassa produzida, depende da percentagem de absorção e da eficiência de utilização da energia absorvida. A quantidade de radiação solar absorvida é um importante fator determinante da produtividade final de uma cultura. Vários estudos têm reportado relação linear entre fitomassa produzida e a energia radiante absorvida ao longo do ciclo para um grande número de espécies (TOLLENAAR; BRUULSEMA, 1988). Entretanto, deve-se considerar que a conversão da radiação absorvida em biomassa depende de mudanças na fotossíntese em função de radiação e temperatura e da fração do carbono fixado pela fotossíntese consumido na respiração (GALLAGHER; BISCOE, 1978).

O aproveitamento, por uma cultura, da luz na faixa do espectro visível depende do índice de área foliar e de parâmetros físicos, biológicos e alométricos que determinam a absorção da radiação incidente (BARNI, 1994). Assim, a fotossíntese do dossel é função da fotossíntese da folha e da interceptação da radiação solar. Já, a interceptação da radiação solar é influenciada pelo índice de área foliar, ângulo da folha, interceptação de luz por outras partes da planta, distribuição de folhas (arranjo de folhas na planta e de plantas no campo), características de absorção de luz pela folha e pela quantidade de radiação incidente. 
Destes fatores, apenas a quantidade de radiação solar não é afetada pela escolha do arranjo de plantas (ARGENTA et al., 2001).

Portanto, a escolha do arranjo de plantas adequado é uma das práticas de manejo mais importante para otimizar a produtividade de grãos das culturas, pois afeta diretamente a interceptação de radiação solar, que é um dos principais fatores determinantes da produtividade (ARGENTA et al., 2001). O espaçamento e a densidade de semeadura definem a população e o arranjo de plantas, sendo que entende-se por espaçamento o intervalo compreendido entre duas fileiras, e, por densidade de plantas, o número de plantas dentro da fileira (AZEVEDO et al., 2007). Teoricamente, o melhor arranjo é aquele que proporciona distribuição mais uniforme de plantas por área.

Com o acréscimo na densidade de plantas e redução do espaçamento entre fileiras de semeadura, é possível otimizar a eficiência da interceptação de luz pelo aumento do índice de área foliar mesmo nos estádios fenológicos iniciais, melhorando o aproveitamento de água e nutrientes, reduzindo a competição inter-específica por esses fatores, aumentando a produção de matéria seca e a produção de grãos (MOLIN, 2000), principalmente pelo maior número de plantas na área.

O efeito da população de plantas na produtividade de monocultivos é um aspecto bastante estudado e bem definido (AZEVEDO et al., 2007). Para Holliday (1960), em culturas como a mamona, cuja fração da biomassa total considerada econômica provém das estruturas reprodutivas, a relação população de plantas/produtividade é parabólica. Alguns experimentos sugerem que normalmente o pico de produção de grãos coincide com a densidade populacional que determina a estabilização do crescimento biológico (EMBRATER, 1979). Assim, em casos extremos (baixas ou altas populações) a produtividade tende a ser reduzida.

PEREIRA (1991) relata que, para a cultura do milho, a produtividade tende a se elevar com o aumento da população, até atingir determinado número de plantas por área, que é considerada como população ótima. Após esse ponto, a produtividade decresce com o aumento do número de plantas por área. Quando a população de plantas é baixa, ocorre certa compensação por meio do aumento no número de estruturas reprodutivas, em razão da prolificidade do genótipo e, ou, variação no tamanho da estrutura reprodutiva, o que pode 
minimizar a diferença da produtividade. A população ideal depende da cultivar, da disponibilidade hídrica, da fertilidade do solo e da época de semeadura.

Híbridos de milho mais precoces (ciclo mais curto) requerem maior densidade de plantas em relação aos de ciclo normal para atingir seu potencial de rendimento (MUNDSTOCK, 1977; SILVA, 1992; TOLLENAAR, 1992). Isso se deve ao fato de os híbridos mais precoces geralmente apresentarem menor altura, folhas menores, menor área foliar por planta e menor sombreamento do dossel da cultura (MUNDSTOCK, 1977; SANGOI, 2000). Estas características morfológicas possibilitam a adoção de menor espaçamento entre plantas na fileira e, consequentemente, de maior densidade de plantas. Esses híbridos normalmente requerem maior população de plantas para a maximização da produtividade de grãos, por necessitarem de mais indivíduos por área para gerar índice de área foliar capaz de potencializar a interceptação da radiação solar (SANGOI, 2000). O mesmo principio pode ser verdadeiro para os cultivares de mamona de porte baixo em comparação aos materiais mais antigos e de porte maior.

A disponibilidade de água é, provavelmente, o principal fator que afeta a escolha da população ótima de plantas (LOOMIS; CONNORS, 1992). A época mais crítica da planta de mamona à deficiência hídrica situa-se no período de florescimento (AZEVEDO et al., 2007; SAVY FILHO 2005). Quando há alta probabilidade de falta de umidade nesta fase, deve-se diminuir a população para que o solo possa suprir as plantas com suas reservas hídricas (CANECCHIO FILHO; FREIRE, 1959). Têm-se observado em alguns trabalhos que densidades mais elevadas só devem ser recomendadas sob condições sem restrição hídrica (AZEVEDO et al., 2007), pois com maior população aumenta-se o índice de área foliar e, consequentemente, o consumo de água (TETIO-KAGHO; GARDNER, 1988). Para a cultura do milho, segundo Johnson et al. (1998), outra prática que pode ser adotada, quando há alta probabilidade de deficiência hídrica, é a redução no espaçamento entre fileiras, mantendo-se constante a população de plantas. Essa medida pode diminuir a competição entre plantas por água, devido a sua distribuição mais equidistante. No entanto, não há informações desse tipo com relação à cultivares de mamona de porte baixo.

A necessidade nutricional das plantas é outro aspecto a ser considerado na escolha do arranjo e da população de plantas, sendo que a população ótima pode variar de acordo com a espécie cultivada (AZEVEDO et al., 2007). 
No caso da mamona, solos muito férteis ou intensamente adubados tendem a provocar crescimento exuberante nas plantas, retardam o florescimento, provocam o acamamento, reduzindo a eficiência ou impedindo a mecanização da lavoura, podendo reduzir a produtividade final por aumentar a fração de carbono da fotossíntese dirigido ao crescimento vegetativo. Plantas muito adensadas, em condições de maior umidade relativa, têm menor ventilação interna na copa e favorecem o ataque de mofo cinzento (FERREIRA et al., 2006).

Para a mamoneira de porte anão, a definição da população ideal de plantas é um aspecto complexo (AZEVEDO et al., 2007). Segundo os autores, os materiais encontrados no mercado apresentam grande variação no hábito de crescimento e na habilidade de resposta à variação das condições de cultivo. Elevada população de plantas induzirá a produção de plantas muito altas e sujeitas ao acamamento. Por outro lado, densidades baixas facilitam a infestação de plantas daninhas e a formação de plantas com floração tardia e ramos laterais longos.

Alguns híbridos e cultivares de porte baixo podem ser cultivados em populações tão elevadas quanto 50.000 plantas $\mathrm{ha}^{-1}$, desde que se tenha o controle do fornecimento da água. Configurações de plantio de $1,0 \times 1,0 \mathrm{~m}, 1,0 \times 0,45 \mathrm{~m}, 0,90 \times 0,45 \mathrm{~m}$, $0,70 \times 0,70 \mathrm{~m}$ e $1,0 \times 0,35 \mathrm{~m}$ são usadas com esse tipo de mamoneira (FERREIRA et al., 2006).

Canecchio Filho (1954), baseado na análise conjunta de 16 experimentos, em diversas localidades do estado de São Paulo, concluíram que o espaçamento entre fileiras mais adequado para a mamoneira anã IAC 38 estava compreendido entre $1,0 \mathrm{x}$ $0,45 \mathrm{~m}$ e 1,0 x 0,9 m, que se mostraram muito superiores do que outros mais largos, ou seja, menores populações de plantas. Canecchio Filho e Freire (1959), estudando o efeito de espaçamentos $(1,5 \times 1,20 \mathrm{~m} ; 1,0 \times 0,9 \mathrm{~m}$ e 1,0 x 0,45 m) e doses de fósforo e de potássio na produtividade da mamona de porte anão IAC 38, verificaram que em condições favoráveis de chuva, os espaçamentos mais estreitos (maiores populações de plantas) proporcionaram maiores produtividades. Já em condições de deficiência hídrica, maiores populações não resultaram em maiores produtividades, mesmo em solo de alta fertilidade. Trabalhando também com a cultivar IAC 38, Rocha et al. (1964) observaram maiores produtividades com espaçamentos $1,0 \times 1,0 \mathrm{~m} \mathrm{e} 1,5 \times$ 0,5 m. Assim, para cultivares de porte anão, Azevedo et al. 
(2007) recomendam 1,0 x 0,5 $\mathrm{m}$ em solos de baixa fertilidade, 1,0 × 0,7 m em solos de média fertilidade e 1,5 x 0,5 m para solos de alta fertilidade.

Gondim et al. (2006) avaliando o genótipo CSRN-142 (porte médio) em três espaçamentos entre fileiras $(0,60 \mathrm{~m}, 0,83 \mathrm{~m}$ e $1,05 \mathrm{~m})$ e três densidades $(0,37 \mathrm{~m}, 0,48$ m e 0,60 m), ou seja, distâncias entre plantas na fileira, nas condições de Cariri cearense, constataram produtividade máxima de $1.539 \mathrm{~kg} \mathrm{ha}^{-1}$ no arranjo espacial de $0,60 \mathrm{~m} \times 0,37 \mathrm{~m}$.

Vale (2009), estudando os efeitos de diferentes espaçamentos entre fileiras, sem alterar a distância entre plantas na fileira $(0,50 \times 1,00 \mathrm{~m} ; 0,75 \times 1,00 \mathrm{~m} ; 1,00 \times$ $1,00 \mathrm{~m} ; 1,25 \times 1,00 \mathrm{~m} ; 1,50 \times 1,00 \mathrm{~m}$ e 1,75 x 1,00 m) para a cultivar BRS Energia, observou as maiores produtividades nas configurações de 0,5 x 1,0 m e 0,75 x 1,0 m com produtividades de grãos superiores a $2.000 \mathrm{~kg} \mathrm{ha}^{-1}$.

A crescente demanda por materiais apropriados para cultivo em grandes áreas, no período da safra de verão e safrinha, com uso de tecnologias modernas, aproveitando as máquinas utilizadas para outras culturas produtoras de grão, tais como: soja, milho, etc..., tem estimulado o lançamento de novas cultivares de mamona de porte baixo, com características de fruto indeiscente, próprios para colheita mecanizada. Contudo, ainda existem muitas dúvidas a respeito de quais os melhores espaçamentos e populações de plantas para que cada um desses materiais possa atingir máxima produtividade sem incorrer em aumento dos custos de produção. 


\section{MATERIAL E MÉTODOS}

O presente trabalho foi constituído de quatro experimentos, onde foram avaliadas duas cultivares (FCA-PB e IAC 2028), em duas épocas de cultivo (safra de verão e safrinha), conduzidos nos anos 2007/2008 e 2008/2009.

\subsection{Localização e caracterização edafoclimática da área experimental}

Os experimentos foram conduzidos na Fazenda Experimental Lageado, pertencente à Faculdade de Ciências Agronômicas (FCA)/UNESP, Campus de Botucatu, localizada no município de Botucatu-SP, latitude $22^{\circ} 51^{\prime} \mathrm{S}$, longitude $48^{\circ} 26^{\prime} \mathrm{W}$ e altitude de $740 \mathrm{~m}$.

Segundo a classificação climática de Köeppen, o clima predominante na região é do tipo Cwa, caracterizado pelo clima tropical de altitude, com inverno seco e verão quente e chuvoso (LOMBARDI NETO; DRUGOWICH, 1994). Nas Figuras 1 e 2 estão contidos os dados de precipitação pluvial, temperaturas máxima e mínima, umidade relativa do ar e a radiação solar, registrados na Estação Meteorológica da Fazenda Experimental Lageado, pertencente ao Departamento de Recursos Naturais - Setor de Climatologia, durante o período de condução dos experimentos.

Mediante levantamento detalhado realizado por Carvalho et al. (1983) e utilizando-se o Sistema Brasileiro de Classificação dos Solos (EMBRAPA, 1999), o solo da área experimental foi classificado como Latossolo Vermelho distroférrico. 


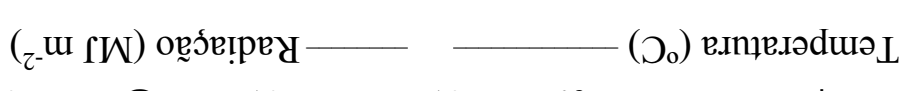

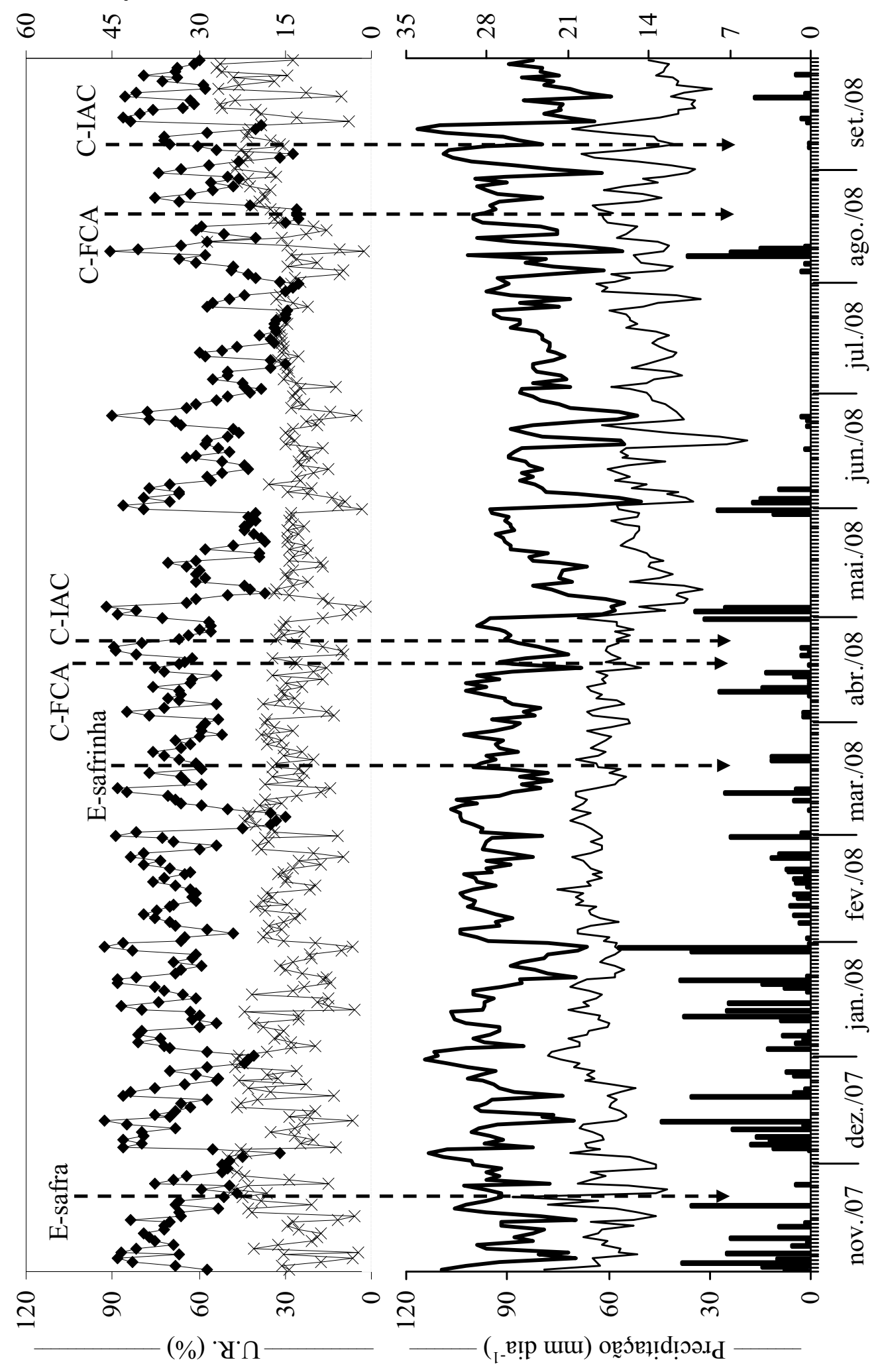

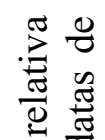

\%

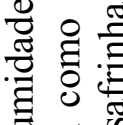

$\exists$ 两

T.

$\times \infty \infty^{0}$

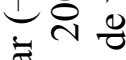

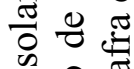

is

ช్

:

iิ

Iิ̊s

节艺

灵文

$\exists$ O

焉

记

윰

(푱

ๆ

爱

峞

击

퓸

苑

Q. 5

今ิ

晃㲵

春卷

馬 I

है है

늠 응

$-$

몽 
8 年

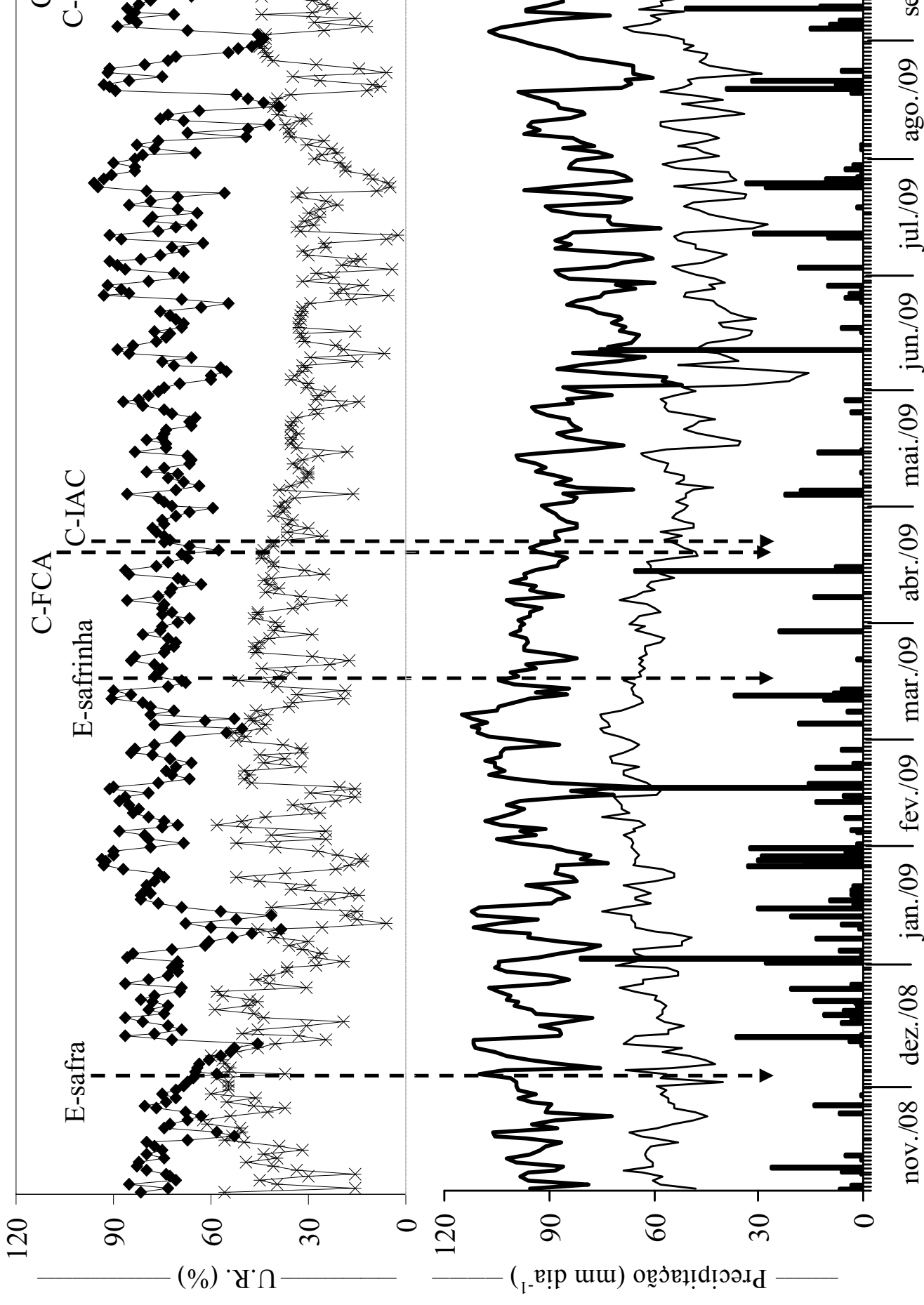

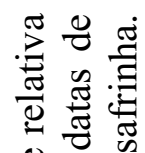

\& 0

n

○ ஸे ヘ

त्ञ

灵㻤 ० T.

요용 층 윰 เి .త్తి 疍 $i^{\sigma} \leftrightarrows$ I0 0 त 寻 导 当 인 륨 茕 觉 응 음 
Antes da instalação de cada experimento foram coletadas amostras de solo na camada de 0 a 0,20 m de profundidade, para a análise química conforme Raij e Quaggio (1983), cujos resultados estão descritos na Tabela 1.

Tabela 1. Atributos químicos do solo, na profundidade de 0 a $0,20 \mathrm{~m}$, antes da instalação dos experimentos.

\begin{tabular}{|c|c|c|c|c|c|c|c|c|c|c|}
\hline Área & $\mathrm{pH}\left(\mathrm{CaCl}_{2}\right)$ & M.O. & P (resina) & $\mathrm{H}+\mathrm{Al}$ & $\mathrm{K}$ & $\mathrm{Ca}$ & $\mathrm{Mg}$ & SB & CTC & $\mathrm{V}$ \\
\hline & & $\left(\mathrm{g} \mathrm{dm}^{-3}\right)$ & $\left(\mathrm{mg} \mathrm{dm}^{-3}\right)$ & 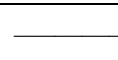 & - & $\mathrm{mmc}$ & $\mathrm{dm}$ & & & $(\%)$ \\
\hline Safra 07/08 & 5,3 & 36 & 37 & 46 & 2,8 & 41 & 15 & 59 & 105 & 56 \\
\hline Safrinha 08 & 5,0 & 38 & 39 & 51 & 4,1 & 31 & 09 & 44 & 95 & 46 \\
\hline Safra 08/09 & 4,3 & 38 & 14 & 67 & 3,3 & 36 & 15 & 54 & 122 & 45 \\
\hline Safrinha 09 & 5,6 & 40 & 26 & 29 & 2,6 & 43 & 22 & 68 & 97 & 70 \\
\hline
\end{tabular}

\subsection{Delineamento experimental e tratamentos}

Foram conduzidos quatro experimentos, sendo, duas cultivares (FCAPB e IAC 2028) em cada época de cultivo (safra de verão e safrinha). Em todos os experimentos, o delineamento experimental foi em blocos casualizados, em esquema de parcelas subdivididas, com quatro repetições. As parcelas foram constituídas por quatro espaçamentos entre fileiras $(0,45,0,60,0,75$ e $0,90 \mathrm{~m})$ e as subparcelas por quatro populações iniciais de plantas $\left(25.000,40.000,55.000\right.$ e 70.000 plantas $\left.^{-1}{ }^{-1}\right)$.

Cada parcela foi constituída por 10, 6, 6 e 6 fileiras nos espaçamentos de $0,45,0,60,0,75$ e $0,90 \mathrm{~m}$, respectivamente, e $20 \mathrm{~m}$ de comprimento. Cada subparcela teve 5 m de comprimento.

A combinação dos quatro espaçamentos entre fileiras com as quatro populações de plantas proporcionou 16 arranjos de planta, ou seja, 16 distâncias entre as plantas na fileira (Tabela 2).

Para as avaliações foram consideradas as linhas centrais desprezando 0,5 m na extremidade de cada fileira de plantas e uma fileira de cada lado da unidade experimental. 
Tabela 2. Distância entre plantas na fileira em função do espaçamento entre fileiras e da população de plantas.

\begin{tabular}{ccccc}
\hline \multirow{2}{*}{ População inicial } & \multicolumn{4}{c}{ Espaçamento $(\mathrm{m})$} \\
\cline { 2 - 5 } & 0,45 & 0,60 & 0,75 & 0,90 \\
\hline (plantas ha $^{-1}$ ) & 0,89 & 0,67 & 0,53 & 0,44 \\
25.000 & 0,56 & 0,47 & 0,33 & 0,28 \\
40.000 & 0,40 & 0,30 & 0,24 & 0,20 \\
55.000 & 0,32 & 0,24 & 0,19 & 0,16 \\
70.000 & & & & \\
\hline
\end{tabular}

\subsection{Caracterização das cultivares de mamona}

A cultivar FCA-PB apresenta porte baixo $(140-180 \mathrm{~cm})$, frutos indeiscentes, suscetibilidade ao mofo-cinzento, doença causada pelo fungo Botryotinia ricini (Goldf.) Wet, teor de óleo em torno de $47 \%$ e ciclo precoce, que varia de 130 a 150 dias (ZANOTTO, 2007) ${ }^{1}$.

A cultivar IAC-2028 adapta-se às condições edafoclimáticas do Estado de São Paulo, apresenta porte baixo $(150-180 \mathrm{~cm})$, frutos indeiscentes, moderada suscetibilidade a doenças, em especial ao mofo-cinzento, teor de óleo em torno de $47 \%$ e ciclo precoce, que varia de 150 a 180 dias, produtividade média de grãos de $2.000 \mathrm{~kg} \mathrm{ha}^{-1}$, adequado para colheita mecanizada com automotriz (SAVY FILHO et al., 2007).

\subsection{Condução dos experimentos em campo}

\subsubsection{Experimento da safra de verão (2007/08 e 2008/09)}

Nos dias 31/10/2007 e 08/11/2008 foram realizadas as dessecações das plantas presentes nas áreas experimentais com a utilização do herbicida glyphosate, na dose de $1.440 \mathrm{~g} \mathrm{ha}^{-1}$ do ingrediente ativo (i.a.) utilizando volume de aplicação de $200 \mathrm{~L} \mathrm{ha}^{-1}$.

\footnotetext{
${ }^{1}$ ZANOTTO, M.D. Características da cultivar de mamona FCA de porte baixo (FCA-PB). (Comunicação pessoal, 2007).
} 
Essas aplicações foram realizadas com pulverizador tratorizado de barras de $12 \mathrm{~m}$ de comprimento e bicos leque 110,02 espaçados de $0,50 \mathrm{~m}$.

A instalação do experimento foi realizada em sistema de plantio direto, ou seja, sem preparo convencional do solo. A abertura dos sulcos e distribuição do adubo foram realizadas com uma semeadora-adubadeira tratorizada, modelo Personale DRILL-13, marca Semeato, regulada de acordo com o espaçamento. A adubação de semeadura constou da aplicação, nos dois anos e em todos os tratamentos, de $150 \mathrm{~kg} \mathrm{ha}^{-1}$ da fórmula NPK 08-28-16, seguindo recomendações de Savy Filho (1996).

As semeaduras foram realizadas manualmente nos dias 09/11/2007 e 21/11/2008, colocando-se nos sulcos as quantidades de sementes necessárias para a obtenção do dobro das populações de plantas desejadas para cada tratamento. As sementes foram tratadas com o fungicida carboxin + tiram $(60+60 \mathrm{~g}$ do i.a. por $100 \mathrm{~kg}$ de sementes $)$ e com o inseticida tiametoxam (140 g do i.a. por $100 \mathrm{~kg}$ de sementes). As emergências de ambas as cultivares ocorreram em 21/11/2007 e 03/12/2008. Aos 10 dias após a emergência (DAE) foram realizados desbastes, deixando-se a população de plantas planejada para cada tratamento.

A adubação de cobertura consistiu da aplicação de $60 \mathrm{~kg} \mathrm{ha}^{-1}$ de $\mathrm{N}$, na forma de sulfato de amônio, em 21/12/2007 e 02/01/2009, ou seja, aos 30 DAE.

Os inícios dos florescimentos da cultivar FCA-PB ocorreram nos dias 02/01/2008 e 12/01/09 e, para a cultivar IAC 2028, nos dias 22/01/2008 e 22/01/2009.

Durante todo o período de desenvolvimento da mamona foram realizadas capinas manuais para o controle das plantas daninhas que surgiram na área. $\mathrm{O}$ controle preventivo do mofo-cinzento foi realizado mediante aplicações dos fungicidas: safra 2007/08 - iprodiona (500 g do i.a. ha ${ }^{-1}$ ) no dia 21/12/2007, procimidona (500 g do i.a. ha ${ }^{-1}$ ) no dia 09/01/2008 e procimidona (500 g do i.a. ha $\left.^{-1}\right)$ e epoxiconazol+piraclostrobina $(20+53,2 \mathrm{~g}$ do i.a. $\mathrm{ha}^{-1}$ ) no dia 31/02/2008; safra 2008/09 - procimidona (500 g do i.a. $\mathrm{ha}^{-1}$ ) no dia 21/01/2009 e 20/02/2009.

As colheitas foram realizadas nos dias 18/04/2008 e 20/04/2009 (FCA-PB) e nos dias 26/04/2008 e 30/04/2009 (IAC 2028), manualmente. 


\subsubsection{Experimento da safrinha (2008 e 2009)}

Em 20/02/08 e 23/02/2009 as plantas presentes na área experimental foram dessecadas mediante a aplicação de herbicida glifosate na dose de $1.440 \mathrm{~g} \mathrm{ha}^{-1}$ do i.a. A instalação do experimento foi realizada em sistema de plantio direto. A abertura dos sulcos e distribuição do adubo foram realizadas com uma semeadora-adubadeira tratorizada modelo Personale DRILL-13, marca Semeato, regulada de acordo com o espaçamento. A adubação de semeadura constou da aplicação, em todos os tratamentos, nos dois anos, de $150 \mathrm{~kg} \mathrm{ha}^{-1}$ da fórmula NPK 08-28-16, seguindo recomendações de Savy Filho (1996).

As semeaduras foram realizadas manualmente nos dias 08/03/08 e 10/03/2009, colocando-se nos sulcos as quantidades de sementes necessárias para a obtenção do dobro das populações de plantas desejada para cada tratamento. As sementes foram tratadas com o fungicida carboxin+tiram $(60+60 \mathrm{~g}$ do i.a por $100 \mathrm{~kg}$ de sementes) e com o inseticida tiametoxam (140 g do i.a. por $100 \mathrm{~kg}$ de semente). A emergência das plântulas ocorreu 10 dias após a semeadura, em 18/03/08 e 20/03/2009. Aos 10 DAE foram realizados desbastes, deixando-se a população de plantas planejada para cada tratamento.

A adubação de cobertura foi realizada aos 30 DAE, aplicando-se 60 $\mathrm{kg} \mathrm{ha}^{-1}$ de $\mathrm{N}$, na forma de sulfato de amônio.

Os inícios dos florescimentos da cultivar FCA-PB ocorreram nos dias 29/04/2008 e 18/05/2009 e, para a cultivar IAC 2028, nos dias 27/05/2008 e 30/05/2009.

Durante todo o período de desenvolvimento da mamona foram realizadas capinas manuais para o controle das plantas daninhas que surgiram na área. $\mathrm{O}$ controle preventivo do mofo-cinzento foi realizado mediante aplicações dos fungicidas procimidona (500 g do 1.a. ha ${ }^{-1}$ ) nos dias 02/06, 24/06 e 11/07/2008 e iprodiona (500 g do i.a. ha $^{-1}$ ) no dia 11/07/2008, na safrinha 2008. Na safrinha 2009 foram aplicados procimidona (500 g do $1 . a . h^{-1}$ ) nos dias 30/06, 29/07, 06/08 e 25/08/2009.

As colheitas foram realizadas nos dias 19/08/2008 e 25/09/2009 (FCA-PB) e nos dias 09/09/2008 e 28/09/2009 (IAC 2028). 


\subsection{Variáveis avaliadas}

As avaliações descritas a seguir foram realizadas em todos os experimentos.

\subsubsection{Matéria seca da parte aérea}

Por ocasião do início do florescimento foi determinada a massa de matéria seca da parte aérea das plantas, coletando-se 5 plantas por unidade experimental, secando-as em estufa com circulação forçada de ar a $60-70{ }^{\circ} \mathrm{C}$, por até 72 horas, e posterior pesagem.

\subsubsection{Diâmetro do caule}

Por ocasião da colheita foi determinado no primeiro internódio da planta, com auxílio de paquímetro, o diâmetro médio do caule, em 10 plantas por unidade experimental.

\subsubsection{Altura da planta}

Por ocasião da colheita foi determinada a altura de planta, mediante a medição da distância entre o solo e o ponto mais alto da planta, em 10 plantas por unidade experimental.

\subsubsection{Altura de inserção do primeiro racemo}

Por ocasião da colheita foi determinada a altura de inserção do primeiro racemo, mediante a medição da distância entre o solo e o ponto de inserção do racemo, em 10 plantas por unidade experimental (esta avaliação não foi realizada na cultivar FCA-PB, no experimento da safra de verão 2007/08).

\subsubsection{Componentes da produção}

a. População final de plantas: a determinação da população final foi realizada na véspera da colheita, considerando duas fileiras centrais, com comprimento de 4 $\mathrm{m}$, na área útil de cada unidade experimental, sendo os resultados convertidos em plantas ha ${ }^{-1}$. 
b. Número de racemos/planta: relação entre número total de racemos e o número total de plantas (determinado em duas fileiras centrais com comprimento de $4 \mathrm{~m}$ na área útil de cada unidade experimental);

c. Número de frutos/racemo: relação entre número total de frutos e o número total de racemos (determinado em duas fileiras centrais com comprimento de $4 \mathrm{~m}$ na área útil de cada unidade experimental);

d. Número médio de grãos/fruto: relação entre número de grãos (determinado em duas amostras de 100 frutos de cada unidade experimental) e o número de frutos destas amostras;

e. Massa de 100 grãos (g): determinada por meio da pesagem de quatro amostras de 100 grãos por unidade experimental. Os dados obtidos foram transformados para $13 \%$ de umidade (base úmida).

\subsubsection{Produtividade de grãos}

Foram colhidos manualmente os racemos das plantas contidos nas duas fileiras centrais com comprimento de quatro m em cada unidade experimental, em uma única ocasião, trilhados, após esta operação, os grãos foram separados e pesados. Posteriormente foi calculada a produtividade em $\mathrm{kg} \mathrm{ha}^{-1}$ e corrigidos para $13 \%$ de umidade (base úmida).

\subsubsection{Teor de óleo no grão}

Para a determinação do teor de óleo, amostras dos grãos foram secadas em estufa a $70^{\circ} \mathrm{C}$ por 24 horas e submetidas à análise por ressonância magnética nuclear. Os dados foram expressos em base seca.

\subsubsection{Produtividade de óleo}

Após a determinação do teor de óleo dos grãos, foi calculada a produtividade de óleo $\left(\mathrm{kg} \mathrm{ha}^{-1}\right)$ para cada unidade experimental. 


\subsection{Análise estatística}

Os dados obtidos, em cada experimento, foram submetidos à análise de variância, segundo o esquema de análise conjunta de experimentos em parcelas subdivididas (CAMPOS, 1984). Porém, como as interações ano x espaçamento, ano $\mathrm{x}$ população de plantas ou ano x espaçamento x população de plantas foram significativas para a maioria das variáveis estudadas, nos quatro experimentos, optou-se por não apresentar as análises conjuntas. $\mathrm{O}$ fator espaçamento entre fileiras foi considerado qualitativo, enquanto a população de plantas foi considerada fator quantitativo. Assim, as médias referentes aos espaçamentos foram comparadas pelo teste Tukey a 5\% de probabilidade, enquanto os efeitos das populações de plantas foram avaliados por meio de análise de regressão, adotando-se como critério para escolha do modelo a magnitude dos coeficientes de regressão significativos ao nível de $5 \%$ de probabilidade. 


\section{RESULTADOS E DISCUSSÃO}

\subsection{Experimento da safra de verão (2007/08 e 2008/09)}

\subsubsection{Cultivar FCA-PB}

Na Tabela 3, constata-se que, nos dois anos agrícolas os tratamentos com maiores populações de plantas promoveram populações finais proporcionalmente menores, quando comparadas com as populações estabelecidas na fase inicial, independente do espaçamento entre fileiras utilizado, ou seja, nos tratamentos mais adensados a percentagem de sobrevivência das plantas foi menor do que naqueles com menores populações. Isso ocorreu, provavelmente, devido a maior competição intra-específica proporcionada pelo aumento de plantas por $\mathrm{m}^{2}$. Para Rocha et al. (1964), o aumento da população de plantas, ou mais especificamente o adensamento das plantas na fileira, proporciona redução da população final de plantas. De acordo com Beltrão et al. (2007a), para cultivares de porte baixo a médio e de ciclo médio, os principais componentes da produção são os números de racemos por planta e o número de frutos por racemo, já no caso dos híbridos de porte baixo, a população de plantas por unidade de área é a característica que assume elevada importância, pois, em altas populações, superiores a 50 mil plantas $\mathrm{ha}^{-1}$, geralmente as plantas híbridas produzem somente dois racemos. Contudo, é importante destacar que quando são utilizadas cultivares de porte baixo, em elevadas populações, o número de racemos por planta 
também fica bastante limitado, aumentando a importância relativa do número de racemos por área.

Tabela 3. População final de plantas obtida na colheita da mamona cultivar FCA-PB em função do espaçamento entre fileiras e da população inicial de plantas, nas safras de verão 2007/08 e 2008/09. Botucatu - SP.

\begin{tabular}{|c|c|c|c|c|c|}
\hline \multirow{2}{*}{ População inicial } & \multicolumn{4}{|c|}{ Espaçamento (m) } & \multirow{2}{*}{ Média } \\
\hline & 0,45 & 0,60 & 0,75 & 0,90 & \\
\hline \multicolumn{6}{|c|}{$-\left(\right.$ plantas $\left.\mathrm{ha}^{-1}\right)$} \\
\hline \multicolumn{6}{|c|}{ Safra 2007/08 } \\
\hline 25.000 & 19.069 & 19.938 & 20.289 & 21.861 & $20.289(81 \%)^{(1)}$ \\
\hline 40.000 & 33.787 & 31.889 & 31.442 & 33.833 & $32.738(82 \%)$ \\
\hline 55.000 & 40.963 & 40.777 & 39.722 & 44.370 & $41.458(75 \%)$ \\
\hline 70.000 & 50.875 & 50.194 & 49.319 & 52.240 & $50.657(72 \%)$ \\
\hline \multicolumn{6}{|c|}{ Safra 2008/09 } \\
\hline 25.000 & 24.880 & 24.944 & 25.000 & 25.000 & $24.956(99 \%)$ \\
\hline 40.000 & 40.000 & 39.889 & 39.972 & 37.963 & $39.456(98 \%)$ \\
\hline 55.000 & 53.703 & 52.778 & 51.111 & 50.000 & $51.898(94 \%)$ \\
\hline 70.000 & 67.592 & 64.583 & 61.111 & 55.555 & $62.210(89 \%)$ \\
\hline
\end{tabular}

Em 2007/08, a matéria seca da parte aérea foi influenciada pelo espaçamento entre fileiras e população de plantas, já em 2008/09 houve efeito do espaçamento entre fileiras e da interação entre os fatores (Tabela 4 e Figura 3). No primeiro ano, o espaçamento de $0,60 \mathrm{~m}$ proporcionou maior produção de massa de matéria seca $(60,1 \mathrm{~g})$, quando comparado com os espaçamentos de 0,45 e $0,75 \mathrm{~cm}$. O aumento da população de plantas proporcionou redução linear da massa de matéria seca, com decréscimo de 40,6\%, independente do espaçamento entre fileiras utilizado (Figura 3A).

No segundo ano, verificou-se que somente as plantas que se encontravam no menor espaçamento $(0,45 \mathrm{~m})$, ou seja, mais bem distribuídas na área, não sofreram influencia da população, tendo produzido em média $47 \mathrm{~g}$ de matéria seca (Figura 3B). Nos demais espaçamentos, essa variável foi reduzida linearmente com o aumento da população de plantas indicando, provavelmente, que houve competição entre plantas, devido 
ao adensamento de plantas na fileira. Segundo Andrade et al. (1971), o adensamento de plantas promove competição por nutrientes, água, luz e $\mathrm{CO}_{2}$, resultando em decréscimo de produção por planta. Na população de 25.000 plantas por ha, o espaçamento entre fileiras de $0,75 \mathrm{~m}$ proporcionou maior produção de fitomassa pelas plantas que o espaçamento de $0,45 \mathrm{~m}$, enquanto, na maior população (70.000 plantas $\mathrm{ha}^{-1}$ ) o menor espaçamento possibilitou maior valor, o que evidencia que plantas mais bem distribuídas na área têm maior produção de massa de matéria seca.

Tabela 4. Matéria seca da parte aérea e diâmetro do caule da cultivar de mamona FCA-PB, nas safras de verão 2007/08 e 2008/09, em função do espaçamento e população de plantas. Botucatu, SP.

\begin{tabular}{|c|c|c|c|c|}
\hline \multirow{2}{*}{ Fontes de variação } & \multicolumn{2}{|c|}{ Matéria seca da parte aérea } & \multicolumn{2}{|c|}{ Diâmetro do caule } \\
\hline & $2007 / 08$ & $2008 / 09$ & $2007 / 08$ & $2008 / 09$ \\
\hline Espaçamento (m) & \multicolumn{2}{|c|}{$\left(\text { g planta }^{-1}\right)^{-}$} & \multicolumn{2}{|c|}{$-(\mathrm{mm})$} \\
\hline 0,45 & $43,9 b^{(1)}$ & $47,5 \mathrm{a}$ & $22,2 \mathrm{a}$ & $23,5 \mathrm{a}$ \\
\hline 0,60 & $60,1 \mathrm{a}$ & $46,8 \mathrm{a}$ & $24,8 \mathrm{a}$ & $24,0 \mathrm{a}$ \\
\hline 0,75 & $45,8 b$ & $51,5 \mathrm{a}$ & $22,2 \mathrm{a}$ & $24,7 \mathrm{a}$ \\
\hline 0,90 & $49,7 \mathrm{ab}$ & $47,0 \mathrm{a}$ & $23,1 \mathrm{a}$ & $25,8 \mathrm{a}$ \\
\hline C.V.(\%) & 19,2 & 20,4 & 13,1 & 8,7 \\
\hline \multicolumn{5}{|l|}{ População (plantas ha ${ }^{-1}$ ) } \\
\hline 25.000 & 63,3 & 54,3 & 25,8 & 26,6 \\
\hline 40.000 & 56,3 & 49,6 & 23,4 & 23,9 \\
\hline 55.000 & 41,5 & 42,8 & 21,8 & 23,9 \\
\hline 70.000 & 38,5 & 45,8 & 22,2 & 23,6 \\
\hline C.V. $(\%)$ & 22,5 & 15,2 & 9,1 & 8,8 \\
\hline \multicolumn{5}{|l|}{ Teste F } \\
\hline Espaçamento (E) & $9,16^{* *}$ & $0,82 \mathrm{~ns}$ & $2,47 \mathrm{~ns}$ & $3,36 \mathrm{~ns}$ \\
\hline \multicolumn{5}{|l|}{ População inicial (P) } \\
\hline Reg. Linear & $50,41 * *$ & $15,54 * *$ & $43,66^{* *}$ & $14,04 * *$ \\
\hline Reg. Quadrática & $0,52 \mathrm{~ns}$ & $4,40 *$ & $2,76 \mathrm{~ns}$ & $5,17 *$ \\
\hline Ex P & $1,54 \mathrm{~ns}$ & $2,88^{*}$ & $0,54 \mathrm{~ns}$ & $1,17 \mathrm{~ns}$ \\
\hline
\end{tabular}



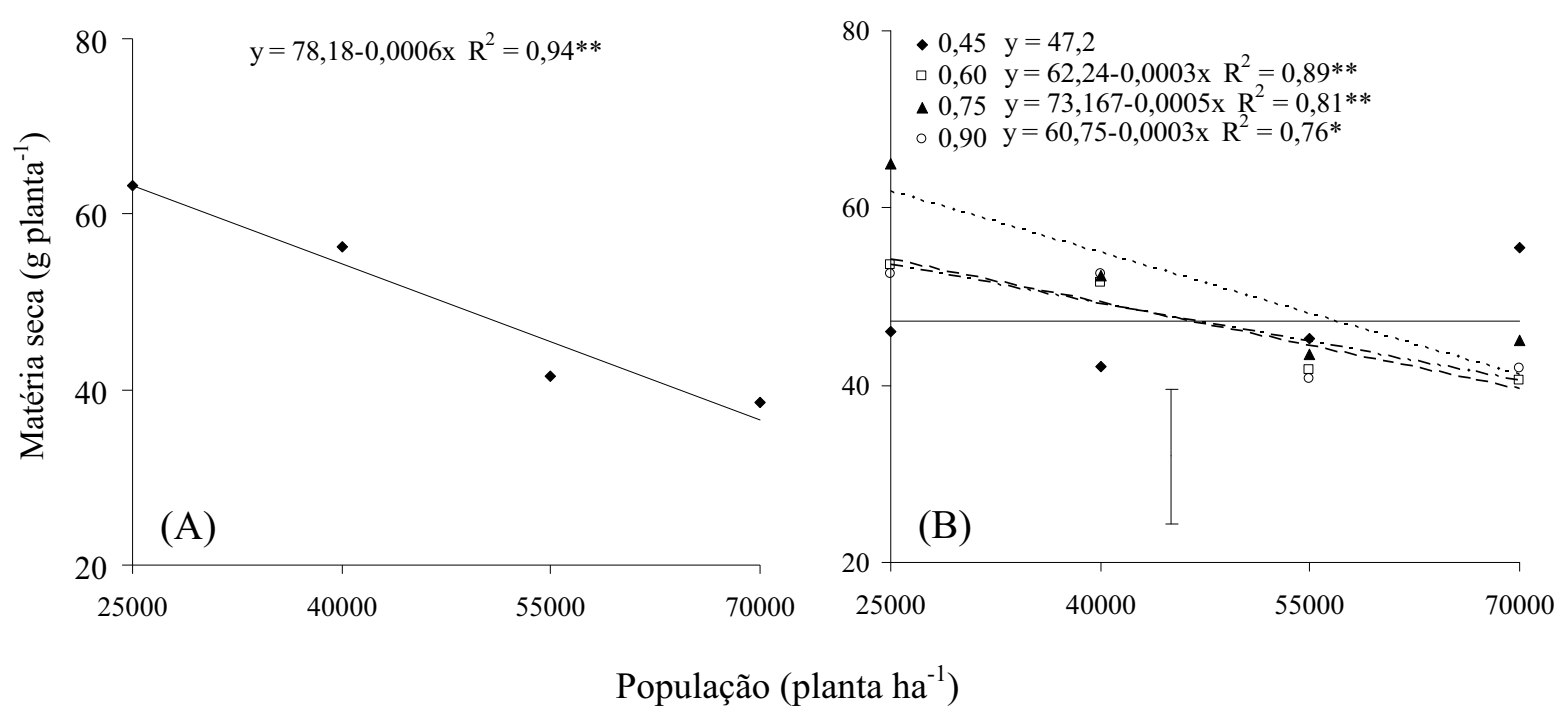

Figura 3. Matéria seca da parte aérea da cultivar de mamona FCA-PB em função da população de plantas, na média de quatro espaçamentos entre fileiras na safra de verão 2007/08 (A) e cada um dos quatro espaçamentos entre fileiras na safra de verão $2008 / 09$ (B). * e ** são significativos a $5 \%$ e $1 \%$ de probabilidade pelo teste $\mathrm{F}$, respectivamente.

Nas duas safras de verão, o diâmetro do caule sofreu influencia apenas da população de plantas (Tabela 4), com redução dessa variável em função do aumento da população de plantas (Figura 4). As plantas que se encontrava em menor competição $\left(25.000\right.$ planta $\left.\mathrm{ha}^{-1}\right)$ tiveram maior diâmetro caulinar, resultado semelhante ao observado para massa de matéria seca da parte aérea (Figura 3). A redução do diâmetro do caule com o incremento da população de plantas pode ser explicada pela maior competição verificada nessas condições. Desta maneira, a repetibilidade dos efeitos observados nos dois anos permite afirmar que entre os fatores estudados, a população de plantas é o que mais influencia no diâmetro do caule. 


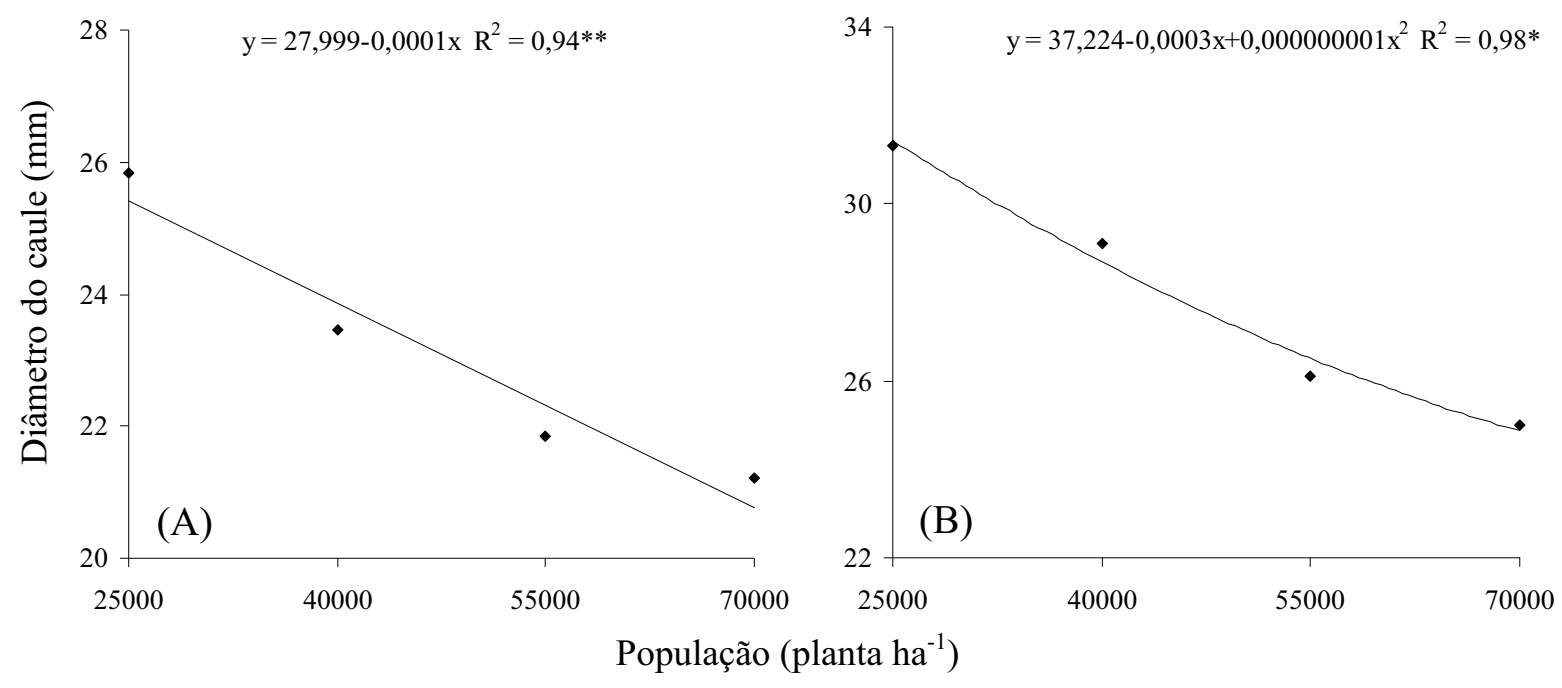

Figura 4. Diâmetro do caule da cultivar de mamona FCA-PB em função da população de plantas nas safras de verão 2007/08 (A) e 2008/09 (B). * e ** são significativos a $5 \%$ e $1 \%$ de probabilidade pelo teste $\mathrm{F}$.

A altura da planta não foi influenciada pelos fatores estudados (Tabela 5). Verificou-se nas safras de verão, que a cultivar FCA-PB apresentou altura média das plantas de 1,56 m. A característica de porte baixo da cultivar FCA-PB, provavelmente, fez com que as plantas cultivadas em condições de espaçamentos reduzidos e/ou elevadas populações, apesar de terem apresentado menor produção de massa de matéria seca, devido à competição intra-específica, não tiveram sua altura alterada. Kittock e Williams (1970) não obtiveram efeito na altura das plantas de híbridos de mamona com o adensamento das plantas na fileira. Gondim et al. (2006) também não verificaram influência do espaçamento entre fileiras e entre plantas na altura das plantas da cultivar CSRN-142, em condições de sequeiro.

A altura de inserção do primeiro racemo foi avaliada apenas no segundo ano de condução do experimento da safra de verão (Tabela 5). A população de plantas e a interação entre a população de plantas e o espaçamento entre fileiras influenciou essa variável. O aumento da população de plantas nos espaçamentos intermediários $(0,60$ e $0,75 \mathrm{~m}$ ) proporcionou incremento linear na altura de inserção do primeiro racemo (Figura 5). Já nos espaçamentos de $0,45 \mathrm{~m}$ e $0,90 \mathrm{~m}$, não houve alteração nos valores dessa variável. $\mathrm{Na}$ maior população de plantas, os espaçamentos intermediários $(0,60$ e $0,75 \mathrm{~m})$ proporcionaram 
altura de inserção do primeiro racemo significativamente superior ao espaçamento de $0,90 \mathrm{~m}$, sem diferir do espaçamento de $0,45 \mathrm{~m}$ entre fileiras.

Tabela 5. Altura de planta e altura de inserção do primeiro racemo da cultivar de mamona FCA-PB, nas safras de verão 2007/08 e 2008/09, em função do espaçamento e população de plantas. Botucatu, SP.

\begin{tabular}{|c|c|c|c|c|}
\hline \multirow[t]{2}{*}{ Fontes de variação } & \multicolumn{2}{|c|}{$\begin{array}{c}\text { Altura de } \\
\text { planta }\end{array}$} & \multicolumn{2}{|c|}{$\begin{array}{l}\text { Altura de inserção } \\
\text { do } 1^{\circ} \text { racemo }\end{array}$} \\
\hline & $2007 / 08$ & $2008 / 09$ & $2007 / 08$ & $2008 / 09$ \\
\hline Espaçamento (m) & \multicolumn{4}{|c|}{$-(\mathrm{m})^{-}$} \\
\hline 0,45 & $1,50 \mathrm{a}^{(1)}$ & $1,55 \mathrm{a}$ & - & $0,50 \mathrm{a}$ \\
\hline 0,60 & $1,53 \mathrm{a}$ & $1,56 \mathrm{a}$ & - & $0,49 \mathrm{a}$ \\
\hline 0,75 & $1,54 \mathrm{a}$ & $1,60 \mathrm{a}$ & - & $0,53 \mathrm{a}$ \\
\hline 0,90 & $1,61 \mathrm{a}$ & $1,61 \mathrm{a}$ & - & $0,43 \mathrm{a}$ \\
\hline C.V.(\%) & 9,4 & 9,5 & - & 26,1 \\
\hline \multicolumn{5}{|l|}{ População (plantas ha ${ }^{-1}$ ) } \\
\hline 25.000 & 1,58 & 1,61 & - & 0,43 \\
\hline 40.000 & 1,53 & 1,55 & - & 0,44 \\
\hline 55.000 & 1,52 & 1,55 & - & 0,50 \\
\hline 70.000 & 1,54 & 1,60 & - & 0,57 \\
\hline C.V. $(\%)$ & 6,9 & 12,2 & - & 19,2 \\
\hline \multicolumn{5}{|l|}{ Teste F } \\
\hline Espaçamento (E) & $1,77 \mathrm{~ns}$ & $0,62 \mathrm{~ns}$ & - & $1,64 \mathrm{~ns}$ \\
\hline \multicolumn{5}{|l|}{ População inicial (P) } \\
\hline Reg. Linear & $1,04 \mathrm{~ns}$ & $0,06 \mathrm{~ns}$ & - & $19,79 * *$ \\
\hline Reg. Quadrática & $1,72 \mathrm{~ns}$ & $1,22 \mathrm{~ns}$ & - & $1,78 \mathrm{~ns}$ \\
\hline $\mathrm{E} \times \mathrm{P}$ & $0,60 \mathrm{~ns}$ & $0,91 \mathrm{~ns}$ & - & $2,85 * *$ \\
\hline
\end{tabular}




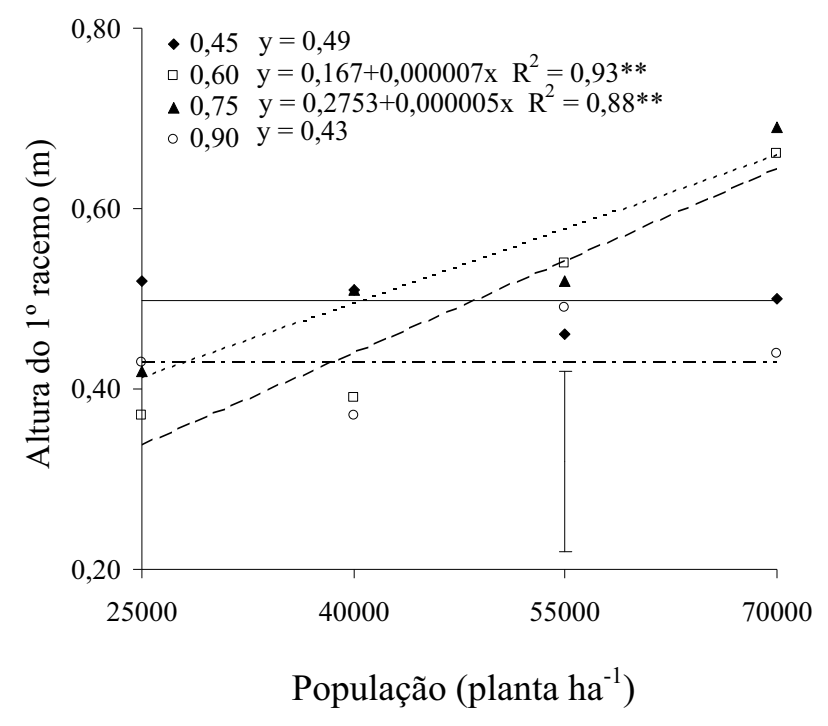

Figura 5. Altura de inserção do primeiro racemo da cultivar de mamona FCA-PB em função da população de plantas e do espaçamento entre fileiras na safra de verão 2008/09. ** é significativo a $1 \%$ de probabilidade pelo teste $\mathrm{F}$.

O número de racemos por planta, nas duas safras de verão, foi influenciado significativamente apenas pela população de plantas (Tabela 6 e Figura 6). O aumento da população de plantas reduziu linearmente os valores dessa variável. Nota-se que o maior número de racemos por planta, nos dois anos agrícolas, foi proporcionado pela menor população (25.000 plantas ha $\left.{ }^{-1}\right)$. Gondim et al. (2006) também verificaram que o número de racemos por planta da cultivar de mamona CSRN-142 foi reduzido com o aumento da densidade de plantas na fileira. Com a redução do espaçamento entre plantas na fileira, a competição por luz, água e nutrientes aumenta e, com isso, ocorre produção de menor número de racemos por planta. Para Almeida et al. (2000), na cultura do milho, relatam que a alteração no arranjo de plantas afeta a qualidade de luz interceptada. Isso ocasiona maior absorção de luz na faixa do vermelho (V) e maior reflexão na faixa do vermelho extremo (VE). Assim, sob tais condições, as plantas recebem mais luz VE refletida, aumentando a relação VE/V. Isso promove modificações em seu crescimento, tais como maior elongação dos entrenós (colmos mais compridos, porém de menor diâmetro), maior dominância apical e altura de inserção de espiga, e assim folhas mais compridas e finas, no caso do milho (KASPERBAUER; KARLEN, 1994). Por favorecer o alongamento dos entrenós ocorre redução em área foliar e 
da ramificação e, consequentemente, redução da produção de estruturas reprodutivas (TAIZ; ZEIGER, 2004).

Tabela 6. Número de racemos por planta, frutos por racemo e grãos por fruto da cultivar de mamona FCA-PB, nas safras de verão 2007/08 e 2008/09, em função do espaçamento e população de plantas. Botucatu, SP.

\begin{tabular}{|c|c|c|c|c|c|c|}
\hline \multirow[t]{2}{*}{ Fontes de variação } & \multicolumn{2}{|c|}{$\begin{array}{c}\mathrm{N}^{\mathrm{o}} \text { de racemos por } \\
\text { planta }\end{array}$} & \multicolumn{2}{|c|}{$\begin{array}{l}\mathrm{N}^{\mathrm{o}} \text { de frutos por } \\
\text { racemo }\end{array}$} & \multicolumn{2}{|c|}{$\begin{array}{l}\text { № de grãos por } \\
\text { fruto }\end{array}$} \\
\hline & $2007 / 08$ & $2008 / 09$ & $2007 / 08$ & 2008/09 & $2007 / 08$ & $2008 / 09$ \\
\hline Espaçamento (m) & \multicolumn{2}{|c|}{$\left(\right.$ racemos planta $\left.^{-1}\right)$} & \multicolumn{2}{|c|}{ (frutos racemo $^{-1}$ ) } & \multicolumn{2}{|c|}{ (grãos fruto $^{-1}$ ) } \\
\hline 0,45 & $5,2 \mathrm{a}^{(1)}$ & $3,6 a$ & $27,3 \mathrm{a}$ & $19,6 \mathrm{a}$ & $2,8 \mathrm{a}$ & $2,9 \mathrm{a}$ \\
\hline 0,60 & $5,6 a$ & $3,5 \mathrm{a}$ & $26,9 \mathrm{ab}$ & $20,3 a$ & $2,6 \mathrm{a}$ & $2,9 a$ \\
\hline 0,75 & $5,4 a$ & $3,5 \mathrm{a}$ & $23,6 \mathrm{c}$ & $21,6 a$ & $2,7 \mathrm{a}$ & $2,9 a$ \\
\hline 0,90 & $5,0 \mathrm{a}$ & $3,4 a$ & $24,4 b c$ & $18,2 \mathrm{a}$ & $2,7 \mathrm{a}$ & $2,9 a$ \\
\hline C.V.(\%) & 14,0 & 7,1 & 10,0 & 17,4 & 4,8 & 2,0 \\
\hline \multicolumn{7}{|c|}{ População (plantas ha ${ }^{-1}$ ) } \\
\hline 25.000 & 6,1 & 5,0 & 29,2 & 20,3 & 2,7 & 2,9 \\
\hline 40.000 & 5,6 & 3,6 & 25,8 & 20,3 & 2,7 & 2,9 \\
\hline 55.000 & 4,9 & 2,9 & 24,9 & 20,5 & 2,7 & 2,9 \\
\hline 70.000 & 4,6 & 2,5 & 22,2 & 18,5 & 2,8 & 2,7 \\
\hline C.V.(\%) & 11,0 & 6,5 & 10,8 & 11,4 & 5,8 & 3,5 \\
\hline \multicolumn{7}{|l|}{ Teste F } \\
\hline Espaçamento (E) & $1,84 \mathrm{~ns}$ & $2,82 \mathrm{~ns}$ & $8,14 * *$ & $2,61 \mathrm{~ns}$ & $1,07 \mathrm{~ns}$ & $2,95 \mathrm{~ns}$ \\
\hline \multicolumn{7}{|l|}{ População inicial (P) } \\
\hline Reg. Linear & $59,16^{* *}$ & $1082,36^{* *}$ & $49,58 * *$ & $4,25^{*}$ & $1,49 \mathrm{~ns}$ & $3,57 \mathrm{~ns}$ \\
\hline Reg. Quadrática & $0,33 \mathrm{~ns}$ & $79,39 * *$ & $0,26 \mathrm{~ns}$ & $2,70 \mathrm{~ns}$ & $0,01 \mathrm{~ns}$ & $1,37 \mathrm{~ns}$ \\
\hline $\mathrm{E} \times \mathrm{P}$ & $0,83 \mathrm{~ns}$ & $1,77 \mathrm{~ns}$ & $1,68 \mathrm{~ns}$ & $0,40 \mathrm{~ns}$ & $1,07 \mathrm{~ns}$ & $2,68 \mathrm{~ns}$ \\
\hline
\end{tabular}

${ }^{(1)}$ Médias seguidas de letras distintas, na coluna, dentro do fator espaçamento, diferem estatisticamente pelo teste de Tukey a $5 \%$ de probabilidade. ${ }^{*}, * *$ e ns são, respectivamente, significativos a $5 \%, 1 \%$ de probabilidade e nãosignificativo pelo teste $\mathrm{F}$.

O número de frutos por racemo, no primeiro ano agrícola, foi influenciado por todos os fatores, porém, no segundo ano, apenas o fator população de plantas afetou esse componente (Tabela 6). Os menores espaçamentos $\left(\begin{array}{ccccc}0,45 & \text { e } & 0,60 & \mathrm{~m}\end{array}\right)$ 
proporcionaram racemos com maior número de frutos, contudo, o espaçamento de 0,60 m não diferiu significativamente do espaçamento de $0,90 \mathrm{~m}$, independentemente da população de plantas. A maior competição entre as plantas na fileira, proporcionada pelos espaçamentos mais largos reduziu o número de frutos por racemo, provavelmente por reduzir o tamanho da estrutura reprodutiva.

O aumento da população de plantas, independente do espaçamento empregado, diminuiu significativamente o número de frutos por racemo (Figura 7). No entanto, o decréscimo foi mais pronunciado no ano 2007/08. Apesar do efeito da população de plantas no número de frutos por racemo no segundo ano, é importante relatar que neste ano os valores dessa variável foram inferiores aos observados no primeiro ano, provavelmente devido a maior mortalidade de plantas ocorridas no primeiro ano, em todos os espaçamentos e populações estudados (Tabela 2). Esses resultados evidenciam a elevada plasticidade da mamoneira (BELTRÃO et al., 2007a).

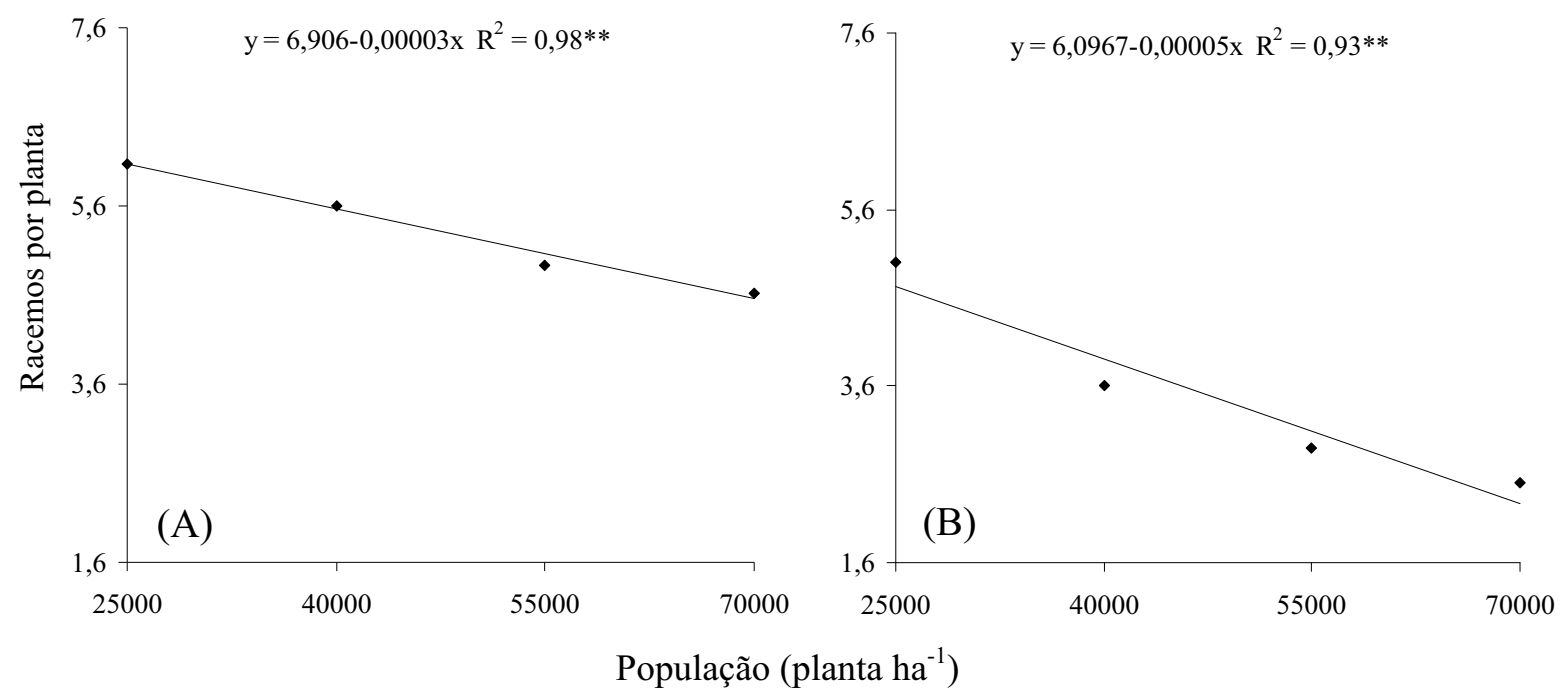

Figura 6. Número de racemos por planta da cultivar de mamona FCA-PB em função da população de plantas, nas safras de verão 2007/08 (A) e 2008/09 (B). ** é significativo a $1 \%$ de probabilidade pelo teste $\mathrm{F}$. 


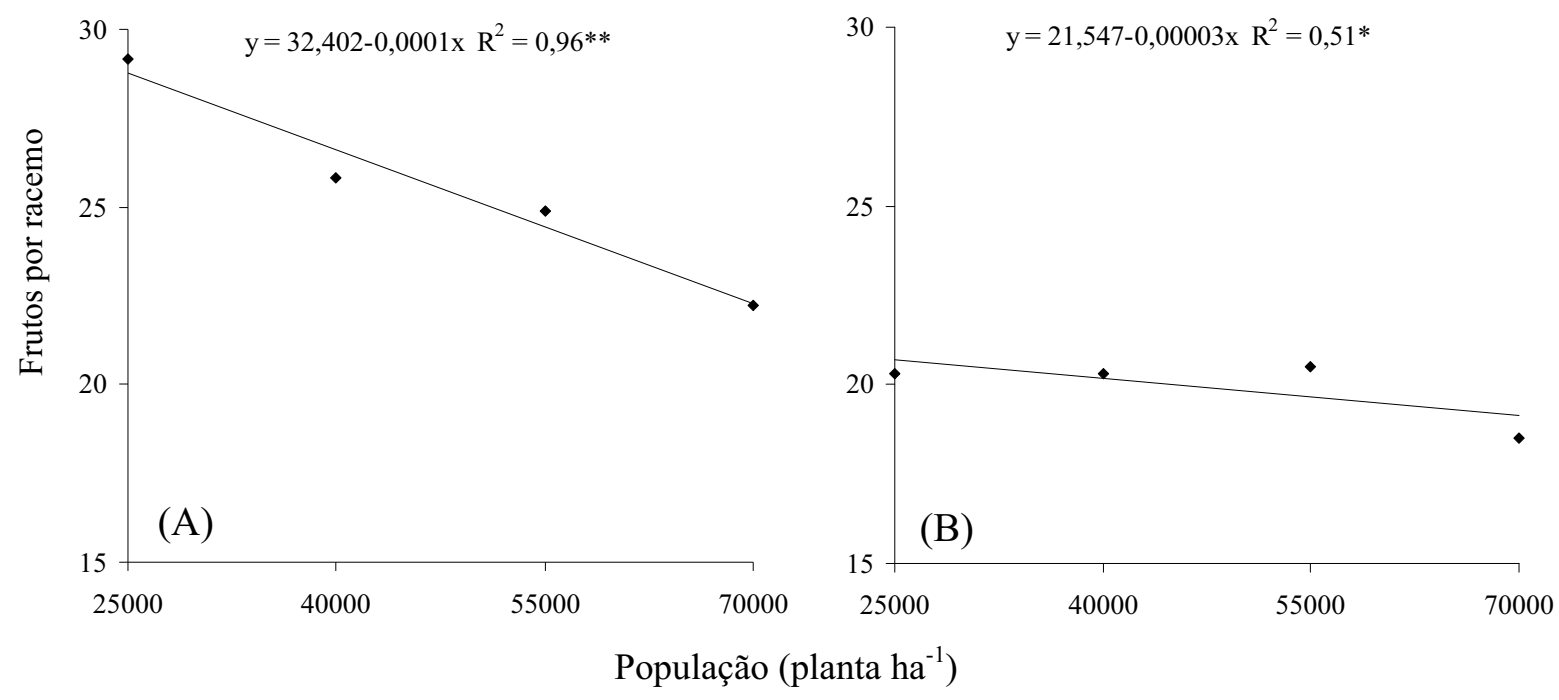

Figura 7. Número de frutos por racemo da cultivar de mamona FCA-PB em função da população de plantas, nas safras de verão 2007/08 (A) e 2008/09 (B). ** e * são significativos a $1 \%$ e $5 \%$ de probabilidade pelo teste $\mathrm{F}$, respectivamente.

O número de grãos por fruto não foi influenciado por nenhum dos fatores estudados, sendo o número médio de grãos por fruto de 2,7 e 2,9 para a safra de verão 2007/08 e 2008/09, respectivamente (Tabela 6). Este componente da produção é pouco influenciado pelo ambiente, ou por fatores exógenos, pois é uma característica de alta herdabilidade (FREIRE et al., 2007).

No primeiro ano do experimento, os maiores espaçamentos entre fileiras proporcionaram maior massa de 100 grãos, o que foi reflexo dos menores números de frutos por racemos obtidos nesses espaçamentos (Tabela 6), possivelmente pela menor competição por assimilados. A mamoneira cultivar FCA-PB apresentou massa de 100 grãos média de $37 \mathrm{~g}$ (Tabela 7). 
Tabela 7. Massa de 100 grãos e produtividade de grãos da cultivar de mamona FCA-PB, nas safras de verão 2007/08 e 2008/09, em função do espaçamento e população de plantas. Botucatu, SP.

\begin{tabular}{|c|c|c|c|c|}
\hline \multirow[t]{2}{*}{ Fontes de variação } & \multicolumn{2}{|c|}{ Massa de 100 grãos } & \multicolumn{2}{|c|}{ Produtividade de grãos } \\
\hline & $2007 / 08$ & $2008 / 09$ & $2007 / 08$ & $2008 / 09$ \\
\hline Espaçamento (m) & \multicolumn{2}{|c|}{$(\mathrm{g})$} & \multicolumn{2}{|c|}{$\left(\mathrm{kg} \mathrm{ha}^{-1}\right)^{-}$} \\
\hline 0,45 & $36,3 b^{(1)}$ & $37,4 \mathrm{a}$ & $4.786 a$ & $3.249 \mathrm{a}$ \\
\hline 0,60 & $36,1 b$ & $37,2 \mathrm{a}$ & $4.761 \mathrm{a}$ & $3.132 \mathrm{a}$ \\
\hline 0,75 & $37,3 \mathrm{ab}$ & $38,9 \mathrm{a}$ & $4.252 b$ & $3.410 \mathrm{a}$ \\
\hline 0,90 & $38,4 \mathrm{a}$ & $37,0 \mathrm{a}$ & $4.445 \mathrm{ab}$ & $2.596 b$ \\
\hline C.V. $(\%)$ & 4,2 & 10,6 & 10,1 & 9,7 \\
\hline \multicolumn{5}{|l|}{ População (plantas ha $\left.{ }^{-1}\right)$} \\
\hline 25.000 & 37,7 & 37,9 & 3.640 & 2.826 \\
\hline 40.000 & 36,4 & 36,9 & 4.582 & 3.117 \\
\hline 55.000 & 36,5 & 38,6 & 4.882 & 3.414 \\
\hline 70.000 & 37,5 & 37,1 & 5.171 & 3.030 \\
\hline C.V. $(\%)$ & 5,2 & 6,2 & 14,1 & 9,6 \\
\hline \multicolumn{5}{|l|}{ Teste F } \\
\hline Espaçamento (E) & $7,28 * *$ & $0,14 \mathrm{~ns}$ & $4,51 *$ & $22,07 * *$ \\
\hline \multicolumn{5}{|l|}{ População inicial (P) } \\
\hline Reg. Linear & $0,04 \mathrm{~ns}$ & $0,03 \mathrm{~ns}$ & $46,22 * *$ & $7,46 * *$ \\
\hline Reg. Quadrática & $5,55 \mathrm{~ns}$ & $0,18 \mathrm{~ns}$ & $4,12 *$ & $20,51 * *$ \\
\hline Ex P & $0,74 \mathrm{~ns}$ & $1,00 \mathrm{~ns}$ & $1,31 \mathrm{~ns}$ & $1,53 \mathrm{~ns}$ \\
\hline
\end{tabular}

Em ambos os anos de cultivo, a produtividade de grãos da cultivar FAC-PB sofreu efeitos isolados do espaçamento entre fileiras e da população de plantas (Tabela 7) e (Figura 8). Em 2007/08, os menores espaçamentos $\left(\begin{array}{llll}0,45 & \text { e } & 0,60 & \mathrm{~m}\end{array}\right)$ proporcionaram as maiores produtividades, diferindo significativamente do espaçamento de 0,75 m, que obteve a menor média. Em 2008/09, as maiores produtividades foram obtidas nos menores espaçamentos entre fileiras $(0,45,0,60$ e $0,75 \mathrm{~m})$, que proporcionaram produtividade média de $3.264 \mathrm{~kg} \mathrm{ha}^{-1}$, ou seja, 25,7\% superior à produtividade obtida no espaçamento de $0,90 \mathrm{~m}\left(2.596 \mathrm{~kg} \mathrm{ha}^{-1}\right)$. Severino et al. (2006b), apesar de terem trabalhado com espaçamentos 
bem mais amplos, também verificaram maiores produtividades de grãos da cultivar BRS Nordestina, com redução do espaçamento entre fileiras. É importante ressaltar que no presente trabalho, o aumento no espaçamento entre fileiras promoveu adensamento de plantas na fileira, independentemente da população utilizada (Tabela 2), e isso, provavelmente, ocasionou a competição entre as plantas na fileira. As maiores produtividades de grãos obtidas em menores espaçamentos entre fileiras deve-se à melhor distribuição das plantas na área, mesmo utilizando populações elevadas. Segundo Andrade et al. (1971), o adensamento de plantas promove competição por nutrientes, água, luz e $\mathrm{CO}_{2}$, resultando em decréscimo de produção por planta. Canecchio Filho (1954) verificou que mesmo com o adensamento de plantas na fileira e a redução do espaçamento entre fileiras há o aumento da produtividade da mamoeira de porte baixo.

A população de plantas influenciou a produtividade de grãos de forma quadrática, nos dois anos agrícolas (Figura 8). No primeiro ano, a maior produtividade foi obtida com a maior população estudada (70.000 plantas ha ${ }^{-1}$ ) (Figura 8A). No segundo ano, a

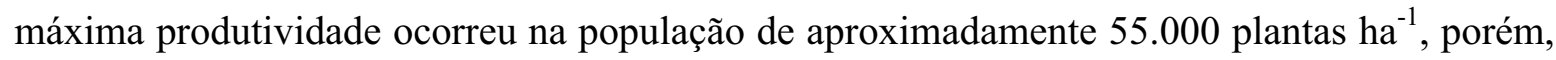
decrescendo na maior população (Figura 8B). Apesar do aumento da população de plantas ter proporcionado redução no número de racemos por planta e de frutos por racemo, proporcionou a obtenção de um maior número de racemos e frutos por área e, consequentemente, maior produtividade de grãos (Figuras 6, 7 e 8). Segundo Rocha et al. (1964), o aumento da população de plantas num mesmo espaçamento entre fileira, promoveu redução na produção de grãos por planta, porém, com o aumento da produtividade por área. Gondim et al. (2006) verificaram que a redução do espaçamento e o aumento da população de plantas incrementaram a produtividade da mamoneira cultivar CSRN-142, em condições de sequeiro. Vale (2009) obteve aumento linear na produtividade de grãos da cultivar BRS Energia, com aumento da população até 20.000 plantas $\mathrm{ha}^{-1}$, alterando apenas o espaçamento entre fileiras, indicando que a produtividade da cultura poderia ser maior em maiores populações, especialmente se a distância entre as plantas na linha também fosse alterada.

No primeiro ano agrícola, as produtividades de grãos foram superiores que às observadas no segundo ano, o que pode ter sido devido às melhores condições de fertilidade do solo (Tabela 1) e condições climáticas (Figuras 1 e 2). Segundo Azevedo et al. (2007), nos híbridos e cultivares de porte baixo, a definição da população de plantas é mais 
complexa, envolvendo a disponibilidade de água, fertilidade do solo e problemas fitossanitários. A elevada produtividade obtida no presente experimento, especialmente no primeiro ano agrícola (Tabela 7 e Figura 8), está relacionada às elevadas populações de plantas utilizadas e a ausência de deficiência hídrica durante o período de cultivo, o que provavelmente favoreceu o crescimento das plantas e a produtividade de grãos, mesmo sob elevadas populações. Canecchio Filho (1954) também constataram elevada produtividade da mamona (acima de $\left.8.000 \mathrm{~kg} \mathrm{ha}^{-1}\right)$ em espaçamentos reduzidos $(1,0 \mathrm{x} 0,60 \mathrm{~m})$.

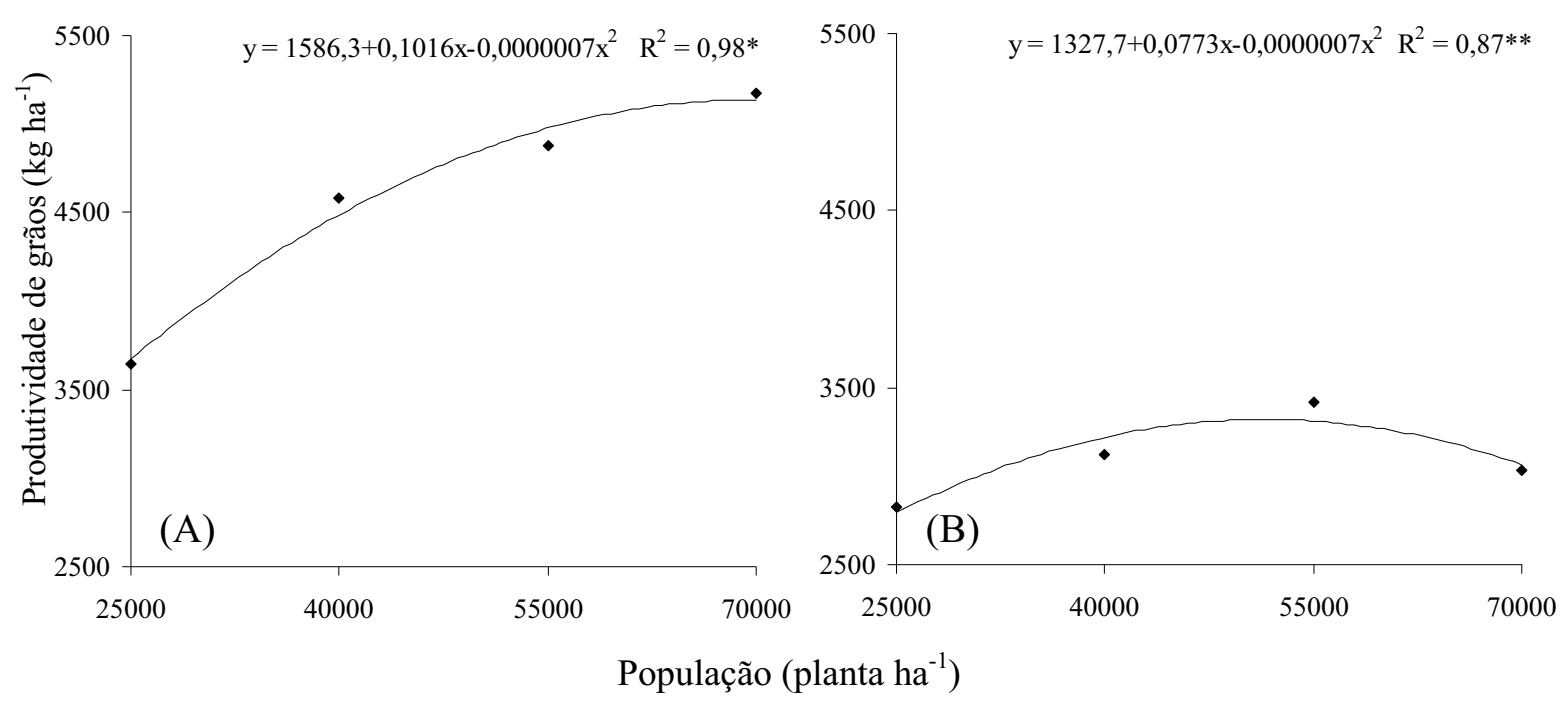

Figura 8. Produtividade de grãos da cultivar de mamona FCA-PB em função da população de plantas, nas safras de verão 2007/08 (A) e 2008/09 (B). * e ** são significativos a $5 \%$ e $1 \%$ de probabilidade pelo teste $\mathrm{F}$, respectivamente.

Para o teor de óleo no grão, constatou-se efeito apenas do espaçamento entre fileira, na safra de verão 2007/08 (Tabela 8). Nota-se que os maiores teores foram obtidos nos espaçamentos de $0,45 \mathrm{~m}$ e $0,90 \mathrm{~m}$, com valores de 50,6\% e 50,8\%, respectivamente, diferindo estatisticamente dos espaçamentos intermediários. Já, Severino et al. (2006b) não observaram, para cultivar BRS Nordestina, influencia do espaçamento entre fileiras no teor de óleo no grão. Vale ressaltar que esses autores utilizaram espaçamentos entre fileiras de 2,0, 2,5, 3,0 e 3,5 m, ou seja, bastante superiores aos empregados nesse trabalho, o que pode justificar a divergência dos resultados.

A produtividade de óleo foi influenciada pelos fatores estudados nos dois anos agrícolas (Tabela 8). No primeiro ano, o menor espaçamento entre fileiras 
proporcionou a maior produtividade de óleo $\left(2.113 \mathrm{~kg} \mathrm{ha}^{-1}\right)$, porém, diferindo estatisticamente apenas do espaçamento de 0,75 m entre fileiras. Já, no segundo ano, os menores espaçamentos entre fileiras $(0,45,0,60$ e $0,75 \mathrm{~m})$ proporcionaram as maiores produtividades de óleo, que foram em média $27,7 \%$ superior ao valor obtido no espaçamento de $0,90 \mathrm{~m}$, que foi significativamente menor que os demais. Os efeitos dos espaçamentos entre fileira na produtividade de óleo foram reflexos dos efeitos na produtividade de grãos, já que o teor de óleo foi pouco influenciado por este fator (Tabelas 7 e 8).

Tabela 8. Teor de óleo no grão e produtividade de óleo da cultivar de mamona FCA-PB, nas safras de verão 2007/08 e 2008/09, em função do espaçamento e população de plantas. Botucatu, SP.

\begin{tabular}{|c|c|c|c|c|}
\hline \multirow{2}{*}{ Fontes de variação } & \multicolumn{2}{|c|}{ Teor de óleo no grão } & \multicolumn{2}{|c|}{ Produtividade de óleo } \\
\hline & $2007 / 08$ & $2008 / 09$ & $2007 / 08$ & $2008 / 09$ \\
\hline Espaçamento (m) & \multicolumn{2}{|c|}{$(\%)$} & \multicolumn{2}{|c|}{$\left(\mathrm{kg} \mathrm{ha}^{-1}\right)^{-}$} \\
\hline 0,45 & $50,6 \mathrm{a}$ & $50,5 \mathrm{a}$ & $2.113 \mathrm{a}$ & $1.430 \mathrm{a}$ \\
\hline 0,60 & $47,6 b$ & $50,1 \mathrm{a}$ & $1.964 \mathrm{ab}$ & $1.368 \mathrm{a}$ \\
\hline 0,75 & $46,5 b$ & $50,3 \mathrm{a}$ & $1.742 b$ & $1.493 \mathrm{a}$ \\
\hline 0,90 & $50,8 \mathrm{a}$ & $49,5 \mathrm{a}$ & $1.964 \mathrm{ab}$ & $1.120 \mathrm{~b}$ \\
\hline C.V.(\%) & 4,8 & 2,8 & 11,7 & 10,7 \\
\hline \multicolumn{5}{|l|}{ População (plantas ha $\left.{ }^{-1}\right)$} \\
\hline 25.000 & 49,7 & 50,2 & 1.583 & 1.236 \\
\hline 40.000 & 47,3 & 49,8 & 1.895 & 1.354 \\
\hline 55.000 & 48,9 & 50,9 & 2.078 & 1.512 \\
\hline 70.000 & 49,6 & 49,6 & 2.225 & 1.309 \\
\hline C.V. $(\%)$ & 7,0 & 3,6 & 15,9 & 11,3 \\
\hline \multicolumn{5}{|l|}{ Teste F } \\
\hline Espaçamento (E) & $13,53 * *$ & $1,44 \mathrm{~ns}$ & $7,26^{* *}$ & $20,4 * *$ \\
\hline \multicolumn{5}{|l|}{ População inicial (P) } \\
\hline Reg. Linear & $0,12 \mathrm{~ns}$ & $0,14 \mathrm{~ns}$ & $37,12 * *$ & $4,85 \mathrm{~ns}$ \\
\hline Reg. Quadrática & $3,25 \mathrm{~ns}$ & $0,95 \mathrm{~ns}$ & $1,14 \mathrm{~ns}$ & $17,55^{* *}$ \\
\hline $\mathrm{E} \times \mathrm{P}$ & $1,70 \mathrm{~ns}$ & $0,28 \mathrm{~ns}$ & $0,28 \mathrm{~ns}$ & $1,18 \mathrm{~ns}$ \\
\hline
\end{tabular}


No primeiro ano agrícola, a produtividade de óleo aumentou linearmente com o incremento da população de plantas (Figura 9A). O aumento da população

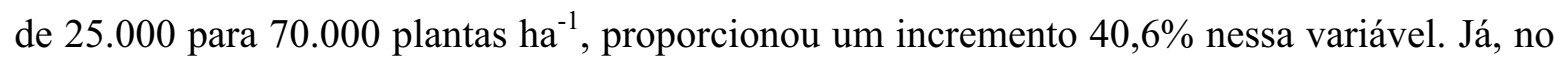
segundo ano, os dados se ajustaram à uma equação quadrática, onde a produtividade máxima estimada foi de $1.357 \mathrm{~kg} \mathrm{ha}^{-1}$, com 45.500 plantas ha ${ }^{-1}$ (Figura 9B). O efeito da população de plantas na produtividade de óleo foi um reflexo da produtividade de grãos (Figura 8B), visto que, a variável teor de óleo, não sofreu efeito da população de plantas.

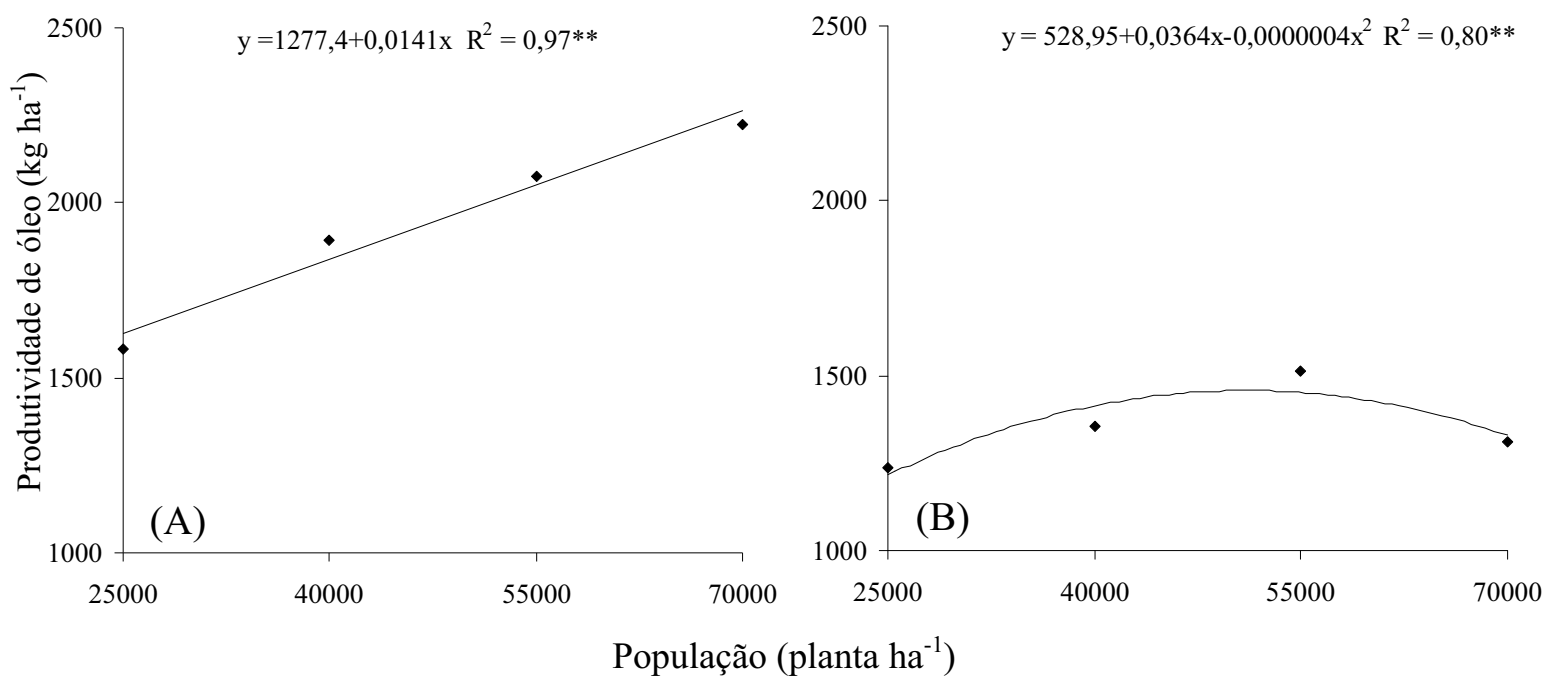

Figura 9. Produtividade de óleo da cultivar de mamona FCA-PB em função da população de plantas, nas safras de verão 2007/08 (A) e 2008/09 (B). ** é significativo a 1\% de probabilidade pelo teste $\mathrm{F}$.

\subsubsection{Cultivar IAC 2028}

Comparando-se as populações obtidas na colheita com as populações inicialmente estabelecidas, é possível verificar que aquelas foram sempre inferiores (Tabela 9). Independentemente do espaçamento entre fileiras utilizado, os tratamentos com maiores populações de plantas promoveram populações finais proporcionalmente menores, quando comparadas com as populações previamente estabelecidas. Segundo Rocha et al. (1964) o aumento da população de plantas, ou mais especificamente o adensamento das plantas na 
fileira, proporciona maior redução da população final em relação à inicialmente estabelecida. Isso ocorreu, provavelmente, devido a maior competição intra-específica proporcionada pelo aumento de plantas por $\mathrm{m}^{2}$. No segundo ano de condução do experimento, notou-se uma redução menos pronunciada na população final de plantas, o que pode estar relacionada à diferenças nas condições climáticas de um ano para o outro (Figuras 1 e 2), visto que, fatores como temperatura, água, luz e nutrientes exercem influência na mortalidade de plantas.

Tabela 9. População final de plantas obtida na colheita da mamona cultivar IAC 2028 em função do espaçamento entre fileiras e da população inicial de plantas, nas safras de verão 2007/08 e 2008/09. Botucatu - SP.

\begin{tabular}{|c|c|c|c|c|c|}
\hline \multirow{2}{*}{ População inicial } & \multicolumn{4}{|c|}{ Espaçamento (m) } & \multirow{2}{*}{ Média } \\
\hline & 0,45 & 0,60 & 0,75 & 0,90 & \\
\hline \multicolumn{6}{|c|}{$-\left(\right.$ plantas $\left.\mathrm{ha}^{-1}\right)$} \\
\hline \multicolumn{6}{|c|}{ Safra 2007/08 } \\
\hline 25.000 & 19.445 & 20.139 & 20.139 & 22.861 & $20.646(83 \%)^{(1)}$ \\
\hline 40.000 & 37.037 & 36.638 & 36.917 & 33.333 & $35.981(90 \%)$ \\
\hline 55.000 & 41.713 & 40.277 & 40.222 & 44.620 & $41.708(76 \%)$ \\
\hline 70.000 & 50.000 & 50.694 & 49.444 & 53.241 & $50.845(73 \%)$ \\
\hline \multicolumn{6}{|c|}{ Safra 2008/09 } \\
\hline 25.000 & 24.905 & 24.944 & 25.000 & 25.000 & $24.962(99 \%)$ \\
\hline 40.000 & 39.990 & 39.817 & 40.000 & 37.500 & $39.327(98 \%)$ \\
\hline 55.000 & 54.630 & 53.472 & 55.000 & 49.999 & $53.275(97 \%)$ \\
\hline 70.000 & 67.593 & 65.273 & 67.222 & 62.037 & $65.531(93 \%)$ \\
\hline
\end{tabular}

No primeiro ano agrícola, a matéria seca da parte aérea foi influenciada estatisticamente pelo espaçamento entre fileiras, população de plantas e pela interação entre estes (Tabela 10). Já, no segundo ano, constatou-se a influencia da população de plantas e da interação espaçamento x população.

No primeiro ano agrícola, o aumento da população de plantas proporcionou redução na produção de matéria seca da parte aérea, em todos os espaçamentos entre fileiras utilizados (Figura 10A). Na menor população de plantas (25.000 plantas ha $\left.{ }^{-1}\right)$, o 
espaçamento de $0,75 \mathrm{~m}$ proporcionou maior valor de matéria seca da parte aérea, em comparação aos demais, o que foi devido à melhor distribuição das plantas obtidas nessa condição (Tabela 2).

Tabela 10. Matéria seca da parte aérea e diâmetro do caule da cultivar de mamona IAC 2028, nas safras de verão 2007/08 e 2008/09, em função do espaçamento e população de plantas. Botucatu, SP.

\begin{tabular}{|c|c|c|c|c|}
\hline \multirow{2}{*}{ Fontes de variação } & \multicolumn{2}{|c|}{ Matéria seca da parte aérea } & \multicolumn{2}{|c|}{ Diâmetro do caule } \\
\hline & $2007 / 08$ & $2008 / 09$ & $2007 / 08$ & $2008 / 09$ \\
\hline Espaçamento (m) & \multicolumn{2}{|c|}{$\left(\right.$ g planta $\left.^{-1}\right)$} & \multicolumn{2}{|c|}{$(\mathrm{mm})$} \\
\hline 0,45 & $109,5 \mathrm{ab}^{(1)}$ & $82,1 \mathrm{a}$ & $28,9 a$ & $27,0 \mathrm{a}$ \\
\hline 0,60 & $104,7 b$ & $80,5 \mathrm{a}$ & $28,5 \mathrm{a}$ & $27,9 a$ \\
\hline 0,75 & $120,1 \mathrm{a}$ & $82,3 \mathrm{a}$ & $28,1 \mathrm{a}$ & $28,1 \mathrm{a}$ \\
\hline 0,90 & $103,5 b$ & $86,7 \mathrm{a}$ & $27,9 a$ & $28,6 \mathrm{a}$ \\
\hline C.V.(\%) & 9,9 & 15,5 & 9,0 & 10,5 \\
\hline \multicolumn{5}{|l|}{ População (plantas ha" ${ }^{-1}$ ) } \\
\hline 25.000 & 140,0 & 106,1 & 32,7 & 31,3 \\
\hline 40.000 & 114,6 & 85,1 & 29,1 & 29,1 \\
\hline 55.000 & 99,9 & 72,1 & 26,7 & 26,1 \\
\hline 70.000 & 83,2 & 68,4 & 24,9 & 25,0 \\
\hline C.V. $(\%)$ & 17,8 & 15,5 & 6,6 & 6,2 \\
\hline \multicolumn{5}{|l|}{ Teste F } \\
\hline Espaçamento (E) & $7,73 * *$ & $0,69 \mathrm{~ns}$ & $0,56 \mathrm{~ns}$ & $0,79 \mathrm{~ns}$ \\
\hline \multicolumn{5}{|l|}{ População inicial (P) } \\
\hline Reg. Linear & $71,96 * *$ & $76,90 * *$ & $151,85^{* *}$ & $128,75^{* *}$ \\
\hline Reg. Quadrática & $0,79 \mathrm{~ns}$ & $7,26 * *$ & $3,23 \mathrm{~ns}$ & $1,68 \mathrm{~ns}$ \\
\hline$E \times P$ & $2,86^{*}$ & $3,55^{* *}$ & $1,64 \mathrm{~ns}$ & $1,74 \mathrm{~ns}$ \\
\hline
\end{tabular}


No segundo ano, apenas no espaçamento de 0,45 m entre fileiras não foi observado efeito da população na produção de matéria seca da parte aérea das plantas, sendo que nos demais espaçamentos essa variável foi reduzida pelo incremento da população (Figura 10). Andrade et al. (1971) relata que o aumento da população de plantas provoca competição por nutrientes, água, luz e $\mathrm{CO}_{2}$, resultando em decréscimo de produção por planta, assim, são confirmados os resultados encontrados nesse trabalho. A semelhança do observado em 2007/08, no segundo ano, houve efeito do espaçamento entre fileiras apenas quando na menor população de plantas, sendo que os espaçamentos de 0,75 e $0,90 \mathrm{~m}$ foram os que proporcionaram os maiores produções de fitomassa.

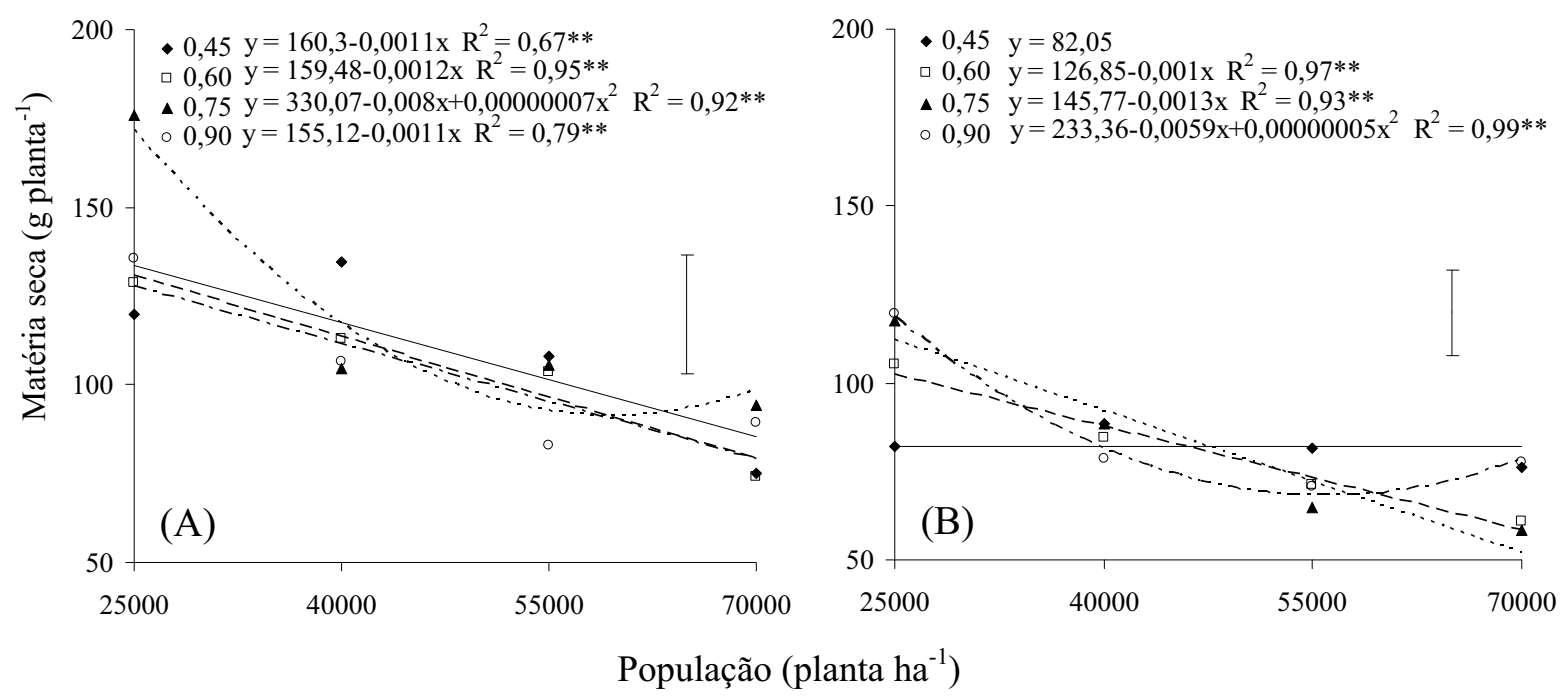

Figura 10. Matéria seca da parte aérea da cultivar de mamona IAC 2028 em função da população de plantas e do espaçamento entre fileiras nas safras de verão 2007/08 (A) e 2008/09 (B). ** é significativo a $1 \%$ de probabilidade pelo teste $\mathrm{F}$.

Nos dois anos agrícolas, o diâmetro do caule foi reduzido linearmente pelo aumento da população de plantas (Tabela 10 e Figura 11). A alteração no arranjo de plantas afeta a qualidade de luz interceptada e ocasiona maior absorção de luz na faixa do vermelho (V) e maior reflexão na do vermelho extremo (VE). Assim, sob tais condições, as plantas recebem mais luz VE refletida, aumentando a relação VE/V, o que promove modificações em seu crescimento, tais como caules mais compridos, porém, mais finos (KASPERBAUER; KARLEN, 1994). 


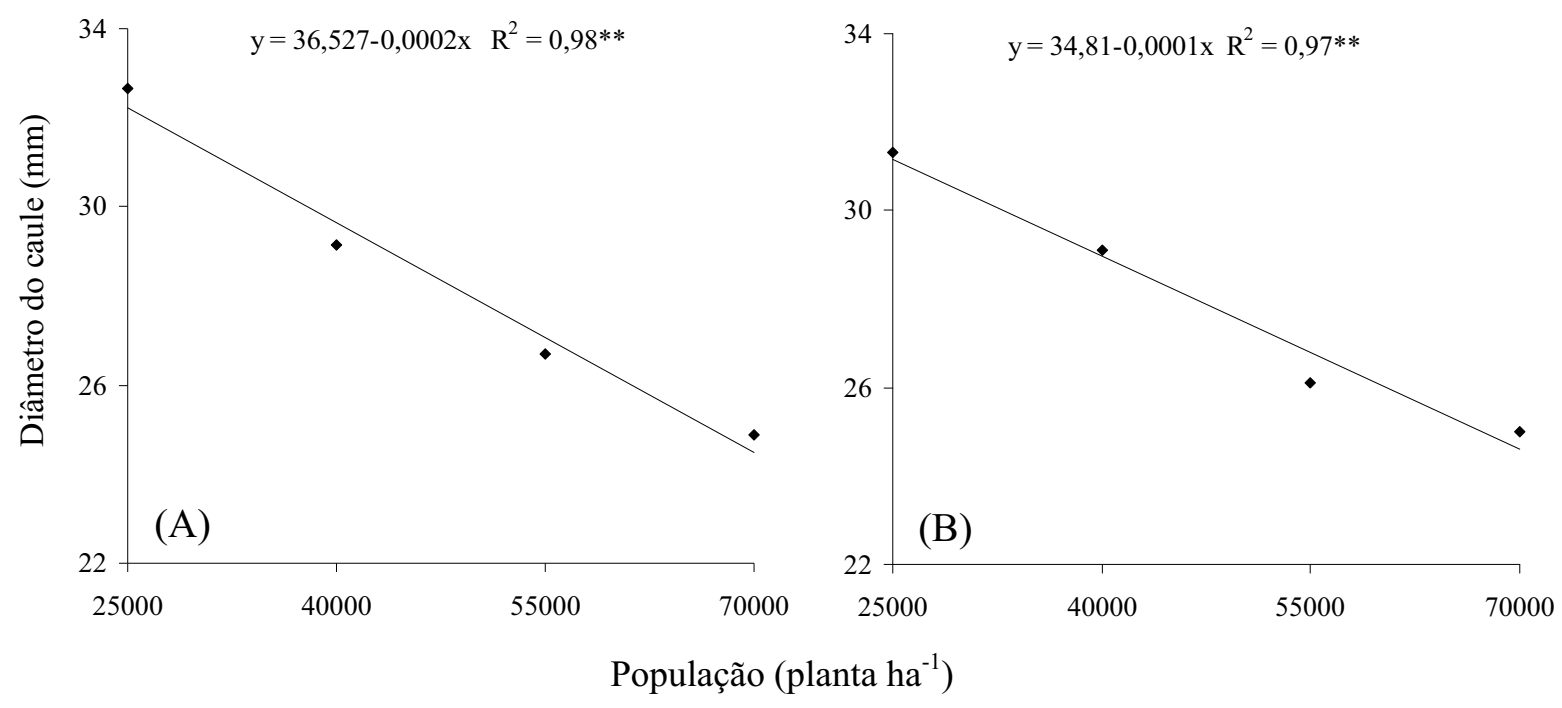

Figura 11. Diâmetro do caule da cultivar de mamona IAC 2028, em função da população de plantas nas safras de verão 2007/08 (A) e 2008/09 (B). ** é significativo a 1\% de probabilidade pelo teste $\mathrm{F}$.

A altura de planta foi influenciada, apenas no primeiro ano agrícola, pela população de plantas (Tabela 11 e Figura 12). Independente do espaçamento utilizado, o incremento no número de plantas por área proporcionou aumento linear na altura média das plantas. O maior adensamento das plantas, provavelmente, proporcionou maior competição por luz e, consequentemente, estiolamento das mesmas. Em condições de competição, ou seja, altas populações de plantas, essas respondem com um crescimento mais rápido da altura a fim de evitar o sombreamento e aumentar suas chances de crescer acima do dossel, o que, porém, sacrifica o crescimento do diâmetro do caule e a matéria seca da parte aérea (TAIZ; ZEIGER, 2004). Segundo Milani et al. (2006), a altura da planta de mamona é controlada por fatores genéticos e ambientais, o que pode justificar os diferentes efeitos entre os anos estudados. Goldim et al. (2004; 2006) e Vale (2009), estudando a cultivar BRS Energia, verificaram que o aumento da população de plantas resultou em plantas mais altas. Severino et al. (2006a), utilizando a cultivar BRS Nordestina relatam que, em ano de boa disponibilidade hídrica, o estreitamento do espaçamento de plantio de 3,5 $\mathrm{m}$ para 2,0 $\mathrm{m}$ promoveu aumento da altura das plantas. Já, em outro estudo, Severino et al. (2006b), estudando a otimização do espaçamento na mesma cultivar, observaram um decréscimo na altura das plantas quando submetidas a 
espaçamentos mais estreitos entre as linhas de plantio, fato este ocorrido devido a fatores ambientais e ou genéticos, conforme relataram os autores.

Tabela 11. Altura da planta e altura de inserção do primeiro racemo da cultivar de mamona IAC 2028, nas safras de verão 2007/08 e 2008/09, em função do espaçamento e população de plantas. Botucatu, SP.

\begin{tabular}{|c|c|c|c|c|}
\hline \multirow[t]{2}{*}{ Fontes de variação } & \multicolumn{2}{|c|}{$\begin{array}{c}\text { Altura de } \\
\text { planta }\end{array}$} & \multicolumn{2}{|c|}{$\begin{array}{l}\text { Altura de inserção } \\
\text { do } 1^{1} \text { racemo }\end{array}$} \\
\hline & $2007 / 08$ & $2008 / 09$ & $2007 / 08$ & $2008 / 09$ \\
\hline Espaçamento (m) & \multicolumn{4}{|c|}{$-(\mathrm{m})$} \\
\hline 0,45 & $1,78 \mathrm{a}^{(1)}$ & $1,83 \mathrm{a}$ & $0,84 b$ & $0,64 \mathrm{a}$ \\
\hline 0,60 & $1,74 \mathrm{a}$ & $1,78 \mathrm{a}$ & $0,87 \mathrm{~b}$ & $0,75 \mathrm{a}$ \\
\hline 0,75 & $1,78 \mathrm{a}$ & $1,89 \mathrm{a}$ & $0,84 b$ & $0,70 \mathrm{a}$ \\
\hline 0,90 & $1,88 \mathrm{a}$ & $1,91 \mathrm{a}$ & $0,93 \mathrm{a}$ & $0,67 \mathrm{a}$ \\
\hline C.V.(\%) & 8,1 & 6,6 & 5,6 & 25,8 \\
\hline \multicolumn{5}{|l|}{ População (plantas ha ${ }^{-1}$ ) } \\
\hline 25.000 & 1,73 & 1,87 & 0,82 & 0,72 \\
\hline 40.000 & 1,79 & 1,83 & 0,84 & 0,72 \\
\hline 55.000 & 1,82 & 1,88 & 0,90 & 0,66 \\
\hline 70.000 & 1,84 & 1,83 & 0,93 & 0,67 \\
\hline C.V. $(\%)$ & 6,0 & 6,0 & 6,4 & 17,0 \\
\hline \multicolumn{5}{|l|}{ Teste $\mathrm{F}$} \\
\hline Espaçamento (E) & $2,68 \mathrm{~ns}$ & $3,48 \mathrm{~ns}$ & $12,25 * *$ & $1,06 \mathrm{~ns}$ \\
\hline \multicolumn{5}{|l|}{ População inicial (P) } \\
\hline Reg. Linear & $10,25 * *$ & $0,37 \mathrm{~ns}$ & $39,92 * *$ & $2,16 \mathrm{~ns}$ \\
\hline Reg. Quadrática & $0,77 \mathrm{~ns}$ & $0,18 \mathrm{~ns}$ & $0,20 \mathrm{~ns}$ & $0,08 \mathrm{~ns}$ \\
\hline $\mathrm{E} \times \mathrm{P}$ & $0,39 \mathrm{~ns}$ & $0,81 \mathrm{~ns}$ & $1,76 \mathrm{~ns}$ & $1,08 \mathrm{~ns}$ \\
\hline
\end{tabular}




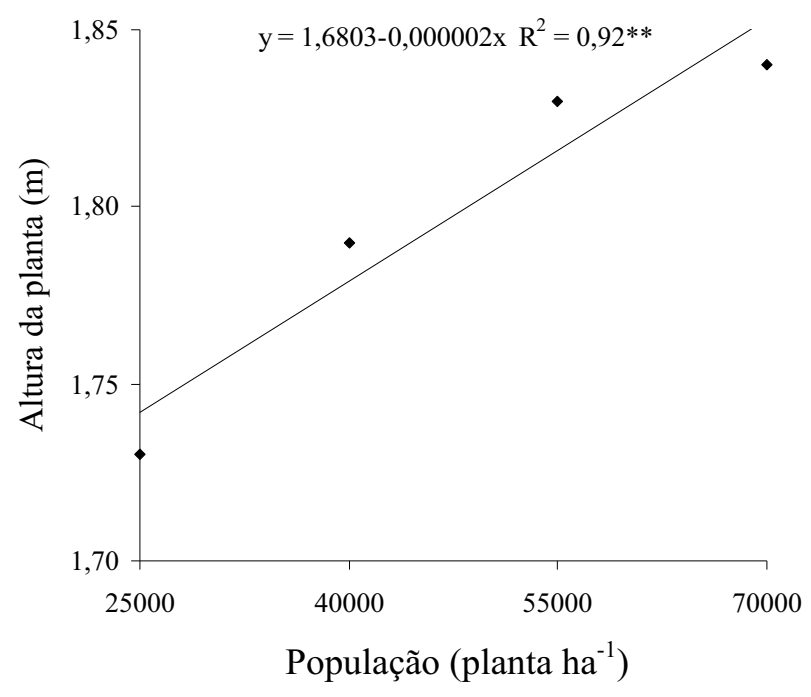

Figura 12. Altura da planta da cultivar de mamona IAC 2028, em função da população de plantas na safra de verão $2007 / 08$. ** é significativo a $1 \%$ de probabilidade pelo teste F.

A altura do primeiro racemo sofreu influência dos fatores estudados, apenas no primeiro ano (Tabela 11). O maior valor de altura da inserção do primeiro racemo $(0,93 \mathrm{~m})$ foi obtido no espaçamento de $0,90 \mathrm{~m}$ entre fileiras, diferindo dos demais. De acordo com Severino et al. (2006b) as mudanças na altura de inserção do primeiro racemo é um indicativo de que o estreitamento do espaçamento entre fileiras, sem alterar o espaçamento entre plantas na fileira, proporciona maior número de plantas por área e, consequentemente, maior crescimento das plantas, o que pode ser devido à maior competição por luz. Essa hipótese justifica os resultados obtidos nesse trabalho, já que no espaçamento de $0,90 \mathrm{~m} \mathrm{o}$ adensamento de plantas na fileira foi maior.

Com o aumento da população de plantas, observou-se um incremento de $0,11 \mathrm{~m}$ na altura do primeiro racemo, no primeiro ano agrícola (Figura 13). Essa maior altura de inserção do primeiro racemo nas maiores populações é resultado da maior altura de planta observado nesses tratamentos (Figura 12). Passamai et al. (2001) trabalhando com a cultura do milho, salienta que as perdas e a pureza dos grãos na colheita mecanizada, dentre outros fatores, são diretamente influenciadas pela altura das plantas e, principalmente, pela altura de inserção da primeira espiga. Plantas mais altas e com inserção de espigas, também 
mais altas, apresentam vantagens na colheita. Assim, esse mesmo conceito pode ser empregado para a cultura da mamona.

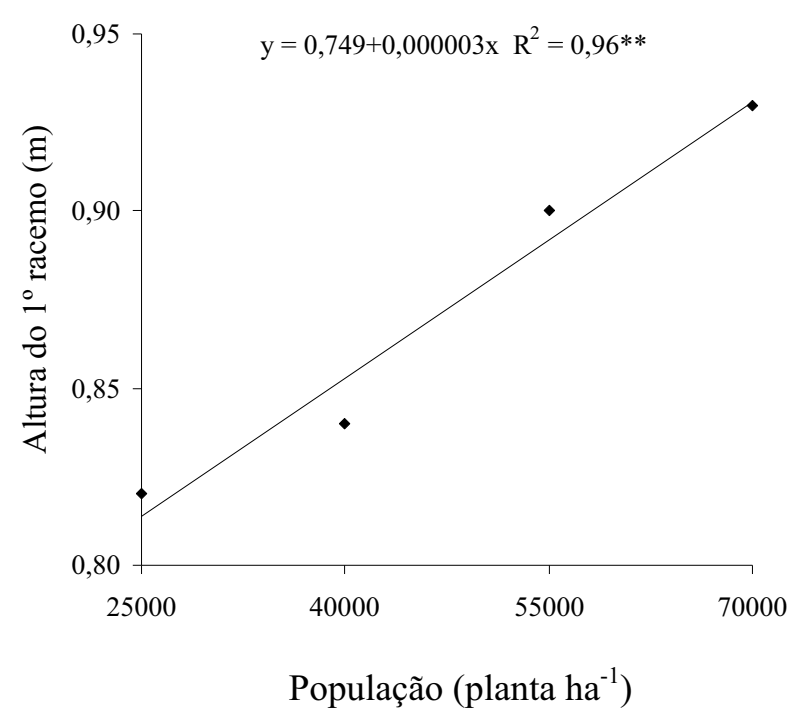

Figura 13. Altura de inserção do primeiro racemo da cultivar de mamona IAC 2028, em função da população de plantas na safra de verão 2007/08. ** é significativo a $1 \%$ de probabilidade pelo teste $\mathrm{F}$.

No primeiro ano agrícola, o número de racemos por planta foi influenciado pela população de plantas e espaçamento entre fileiras (Tabela 12 e Figura 14). Já no segundo ano, verificou-se influência também da interação entre os fatores.

O maior número de racemos por planta foi obtido no espaçamento de 0,45 m entre fileiras, porém, não diferindo estatisticamente dos espaçamentos de 0,60 e 0,75 m, em 2007/08 (Tabela 12). O aumento do espaçamento entre fileira de 0,45 para 0,90 m, reduziu em 22,5\% o valor dessa variável. Em 2008/09, os espaçamentos intermediários proporcionaram número de racemos por planta significativamente maiores que os observados no menor e maior espaçamentos, especialmente quando foi utilizada a população de 25.000 plantas por ha (Figura 14B). A distribuição mais equidistante das plantas, proporcionada pelos espaçamentos de 0,60 e 0,75 m (Tabela 2), provavelmente reduziu a competição entre elas e, consequentemente, fez com que produzissem maior número de estruturas reprodutivas, conforme também foi observado por Vale (2009). 
Tabela 12. Número de racemos por planta e frutos por racemo e grãos por fruto da cultivar de mamona IAC 2028, nas safras de verão 2007/08 e 2008/09, em função do espaçamento e população de plantas. Botucatu, SP.

\begin{tabular}{|c|c|c|c|c|c|c|}
\hline \multirow[t]{2}{*}{ Fontes de variação } & \multicolumn{2}{|c|}{$\begin{array}{c}\mathrm{N}^{-} \text {de racemos por } \\
\text { planta }\end{array}$} & \multicolumn{2}{|c|}{$\begin{array}{c}\text { № de frutos por } \\
\text { racemo }\end{array}$} & \multicolumn{2}{|c|}{$\begin{array}{l}\text { № de grãos por } \\
\text { fruto }\end{array}$} \\
\hline & $2007 / 08$ & $2008 / 09$ & $2007 / 08$ & $2008 / 09$ & $2007 / 08$ & $2008 / 09$ \\
\hline Espaçamento (m) & \multicolumn{2}{|c|}{$\left(\right.$ racemos planta $\left.^{-1}\right)$} & \multicolumn{2}{|c|}{ (frutos racemo $^{-1}$ ) } & \multicolumn{2}{|c|}{ (grãos fruto $^{-1}$ ) } \\
\hline 0,45 & $3,1 \mathrm{a}^{(1)}$ & $2,0 \mathrm{~b}$ & $39,2 \mathrm{ab}$ & $35,2 \mathrm{a}$ & $2,5 b$ & $2,9 \mathrm{a}$ \\
\hline 0,60 & $2,8 \mathrm{ab}$ & $2,5 \mathrm{a}$ & $38,8 \mathrm{ab}$ & $29,5 \mathrm{ab}$ & $2,8 \mathrm{a}$ & $2,9 \mathrm{a}$ \\
\hline 0,75 & $2,7 \mathrm{ab}$ & $2,3 a$ & $43,5 \mathrm{a}$ & $27,8 b$ & $2,8 \mathrm{a}$ & $2,9 \mathrm{a}$ \\
\hline 0,90 & $2,4 \mathrm{~b}$ & $2,1 b$ & $34,5 b$ & $27,2 b$ & $2,8 \mathrm{a}$ & $2,9 \mathrm{a}$ \\
\hline C.V.(\%) & 19,9 & 8,0 & 14,9 & 17,4 & 3,4 & 1,1 \\
\hline \multicolumn{7}{|c|}{ População (plantas ha ${ }^{-1}$ ) } \\
\hline 25.000 & 3,4 & 3,1 & 48,1 & 35,5 & 2,7 & 2,9 \\
\hline 40.000 & 2,7 & 2,4 & 38,4 & 31,7 & 2,8 & 2,9 \\
\hline 55.000 & 2,6 & 1,8 & 35,6 & 27,0 & 2,7 & 2,9 \\
\hline 70.000 & 2,3 & 1,5 & 34,0 & 25,5 & 2,8 & 2,9 \\
\hline C.V.(\%) & 10,6 & 7,8 & 10,8 & 12,8 & 5,3 & 1,2 \\
\hline \multicolumn{7}{|l|}{ Teste $\mathrm{F}$} \\
\hline Espaçamento (E) & $4,22 *$ & $21,25 * *$ & $6,43 *$ & $7,74 * *$ & $43,93 * *$ & $0,93 \mathrm{~ns}$ \\
\hline \multicolumn{7}{|l|}{ População inicial (P) } \\
\hline Reg. Linear & $107,13^{* *}$ & $784,03 * *$ & $90,76^{* *}$ & $65,58 * *$ & $3,59 \mathrm{~ns}$ & $0,01 \mathrm{~ns}$ \\
\hline Reg. Quadrática & $12,19 * *$ & $37,40 * *$ & $14,65 * *$ & $1,49 \mathrm{~ns}$ & $0,96 \mathrm{~ns}$ & $0,27 \mathrm{~ns}$ \\
\hline$E \times P$ & $0,89 \mathrm{~ns}$ & $7,52 * *$ & $1,06 \mathrm{~ns}$ & $0,77 \mathrm{~ns}$ & $1,66 \mathrm{~ns}$ & $2,75 \mathrm{~ns}$ \\
\hline
\end{tabular}

${ }^{(1)}$ Médias seguidas de letras distintas, na coluna, dentro do fator espaçamento, diferem estatisticamente pelo teste de Tukey a $5 \%$ de probabilidade. *, ${ }^{* *}$ e ns são, respectivamente, significativos a $5 \%, 1 \%$ de probabilidade e nãosignificativo pelo teste $\mathrm{F}$.

$\mathrm{O}$ aumento da população de plantas reduziu significativamente o número de racemos por planta, nas duas safras de verão (Figura 14). No primeiro ano agrícola, o efeito negativo da população de plantas no número de racemos por planta foi independente do espaçamento utilizado (Figura 14A). No segundo ano, observou-se maiores decréscimos no número de racemos por planta em função do aumento da população, nos espaçamentos de 0,60 e 0,75 m (Figura 14B), o que está relacionado com a alteração do arranjo de plantas. Goldin et al. (2006) verificaram, em condições de sequeiro, menor quantidade de racemos 
produzido por planta, do genótipo CSRN-142, no menor espaçamento entre fileiras e na maior densidade de plantas na fileira, ou seja, maior população de plantas. Já, no genótipo CSRD-2, os autores não observaram efeito dos tratamentos estudados. Vale (2009) relata uma redução desse componente da produção, com o aumento da população de plantas aliado ao menor espaçamento entre fileiras.
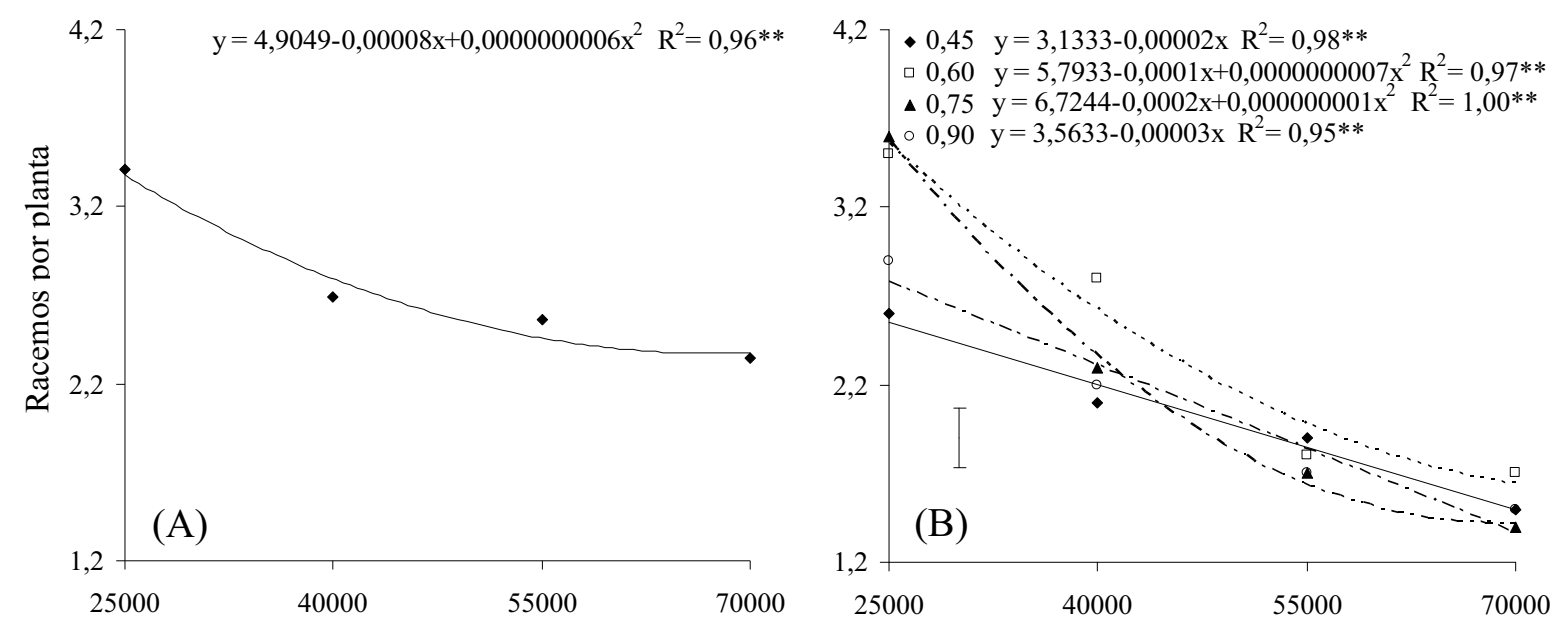

População (planta ha ${ }^{-1}$ )

Figura 14. Número de racemos por planta da cultivar de mamona IAC 2028 em função da população de plantas, na média de quatro espaçamentos entre fileiras na safra de verão 2007/08 (A) e cada um dos quatro espaçamentos entre fileiras na safra de verão $2008 / 09$ (B). ${ }^{* *}$ é significativo a $1 \%$ de probabilidade pelo teste $\mathrm{F}$.

Para o número de frutos por racemo pode-se constatar influência de todos os fatores, em ambas as safras de verão (Tabela 12). No primeiro ano, o maior número de frutos por racemo foi observado no espaçamento de $0,75 \mathrm{~m}$ entre fileiras, porém, não diferindo dos espaçamentos de 0,45 e 0,60 m. O maior espaçamento entre fileiras $(0,90 \mathrm{~m})$, ou seja, maior adensamento de plantas na fileira, reduziu em $20 \%$ o número de frutos por racemo, quando comparado com o espaçamento de $0,75 \mathrm{~m}$. No segundo ano, nota-se que o aumento do espaçamento ente fileiras reduziu o número de frutos por racemo, sendo o maior valor dessa variável (35,2 frutos) obtido no menor espaçamento $(0,45 \mathrm{~m})$ entre fileiras, que diferiu significativamente dos maiores espaçamentos $(0,75$ e $0,90 \mathrm{~m})$. 
O aumento da população de plantas reduziu o número de frutos por racemo, em ambos os anos de cultivo (Figura 15). Em condições de alta competição, especialmente por luz, proporcionada pela maior população de plantas na área, as plantas, apesar de mais altas, produzem menor quantidade de matéria seca (Figura 10), consequentemente, possuem menor aparato fotossintético, refletindo em menor produção de estruturas reprodutivas (Figura 14 e 15) (TAIZ; ZEIGER, 2004). De acordo com Kasperbauer e Karlen (1994), a qualidade de luz interceptada é afeta pela alteração no arranjo de plantas, isso ocasiona maior absorção de luz na faixa do vermelho (V) e maior reflexão na do vermelho extremo (VE). As plantas recebem mais luz VE refletida, aumentando a relação VE/V, o que leva a modificações em seu crescimento, tais como maior elongação dos entrenós e caules mais finos.

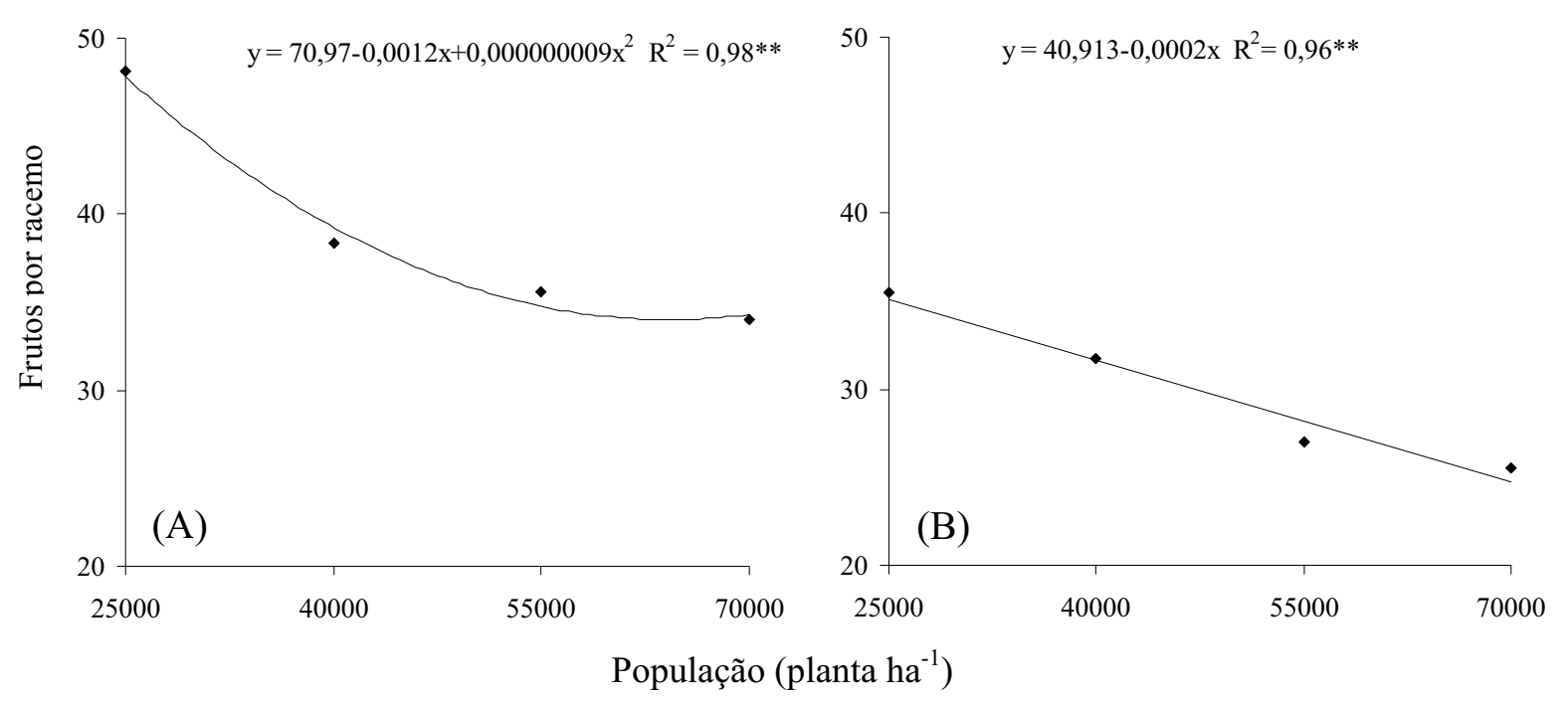

Figura 15. Número de frutos por racemo da cultivar de mamona IAC 2028, em função da população de plantas nas safras de verão 2007/08 (A) e 2008/09 (B). ** é significativo a $1 \%$ de probabilidade pelo teste $\mathrm{F}$.

O número de grãos por frutos sofreu influência apenas do espaçamento entre fileira, na safra de verão 2007/08 (Tabela 12). O menor espaçamento entre fileiras proporcionou o menor número de grãos por fruto, diferindo dos demais espaçamentos, o que foi reflexo, principalmente do maior número de racemos por planta obtido nesse espaçamento, que, provavelmente, proporcionou um efeito compensatório. 
A massa de 100 grãos, no primeiro ano agrícola, foi influenciada pelo espaçamento entre fileiras e população de plantas (Tabela 13). O maior espaçamento entre fileiras proporcionou maior massa de 100 grãos (42,2 g), diferenciando apenas do espaçamento de $0,75 \mathrm{~m}(40,3 \mathrm{~g})$.

Tabela 13. Massa de 100 grãos e produtividade de grãos da cultivar de mamona IAC 2028, nas safras de verão 2007/08 e 2008/09, em função do espaçamento e população de plantas. Botucatu, SP.

\begin{tabular}{|c|c|c|c|c|}
\hline \multirow[t]{2}{*}{ Fontes de variação } & \multicolumn{2}{|c|}{ Massa de 100 grãos } & \multicolumn{2}{|c|}{ Produtividade de grãos } \\
\hline & $2007 / 08$ & 2008/09 & $2007 / 08$ & $2008 / 09$ \\
\hline Espaçamento (m) & \multicolumn{2}{|c|}{$(\mathrm{g})$} & \multicolumn{2}{|c|}{$\left(\mathrm{kg} \mathrm{ha}^{-1}\right)$} \\
\hline 0,45 & $41,8 \mathrm{a}^{(1)}$ & $38,5 \mathrm{a}$ & $4.385 \mathrm{a}$ & $3.402 \mathrm{a}$ \\
\hline 0,60 & $40,8 \mathrm{ab}$ & $38,9 \mathrm{a}$ & $4.239 \mathrm{a}$ & $3.352 \mathrm{a}$ \\
\hline 0,75 & $40,3 b$ & $39,2 \mathrm{a}$ & $4.393 \mathrm{a}$ & $2.969 \mathrm{ab}$ \\
\hline 0,90 & $42,2 \mathrm{a}$ & $39,1 \mathrm{a}$ & $3.657 b$ & $2.538 b$ \\
\hline C.V.(\%) & 3,0 & 5,86 & 11,8 & 23,2 \\
\hline \multicolumn{5}{|l|}{ População (plantas ha" ${ }^{-1}$ ) } \\
\hline 25.000 & 41,9 & 40,2 & 3.712 & 3.198 \\
\hline 40.000 & 41,9 & 39,2 & 4.187 & 3.389 \\
\hline 55.000 & 41,5 & 38,3 & 4.324 & 2.879 \\
\hline 70.000 & 40,6 & 38,0 & 4.450 & 2.795 \\
\hline C.V. $(\%)$ & 3,6 & 5,7 & 15,7 & 17,9 \\
\hline \multicolumn{5}{|l|}{ Teste F } \\
\hline Espaçamento (E) & $7,47 * *$ & $0,27 \mathrm{~ns}$ & $7,98 * *$ & $5,07^{*}$ \\
\hline \multicolumn{5}{|l|}{ População inicial (P) } \\
\hline Reg. Linear & $4,74^{*}$ & $11,74 * *$ & $10,39 * *$ & $7,84^{* *}$ \\
\hline Reg. Quadrática & $0,01 \mathrm{~ns}$ & $0,39 \mathrm{~ns}$ & $1,15 \mathrm{~ns}$ & $1,00 \mathrm{~ns}$ \\
\hline $\mathrm{E} \times \mathrm{P}$ & $2,06 \mathrm{~ns}$ & $1,02 \mathrm{~ns}$ & $0,62 \mathrm{~ns}$ & $2,78^{*}$ \\
\hline
\end{tabular}

No segundo ano, observou-se efeito somente da população de plantas. A razão da massa de 100 grãos no espaçamento de 0,90 m não diferir dos menores espaçamentos $(0,45$ e $60 \mathrm{~m})$, é explicado pelo menor número de racemos por planta e frutos 
por racemos (Tabela 12) obtidos nesse espaçamento, o que consequentemente, proporcionou menor partição dos fotoassimilados.

O aumento da população de plantas, nas duas safras de verão, reduziu linearmente a massa de 100 grãos (Figura 16), sendo o efeito mais pronunciado na safra de verão 2008/09 (Figura 16B). Independente do espaçamento e da população de plantas estudados, a massa de 100 grãos obtida no presente trabalho foi inferior ao relatado por Savy Filho et al. (2007). Porém, os autores utilizaram população de 10.000 plantas ha ${ }^{-1}$, na safra de verão. O que justifica os resultados, visto que, a menor população estudada nesse trabalho foi de 25.000 plantas $\mathrm{ha}^{-1}$.

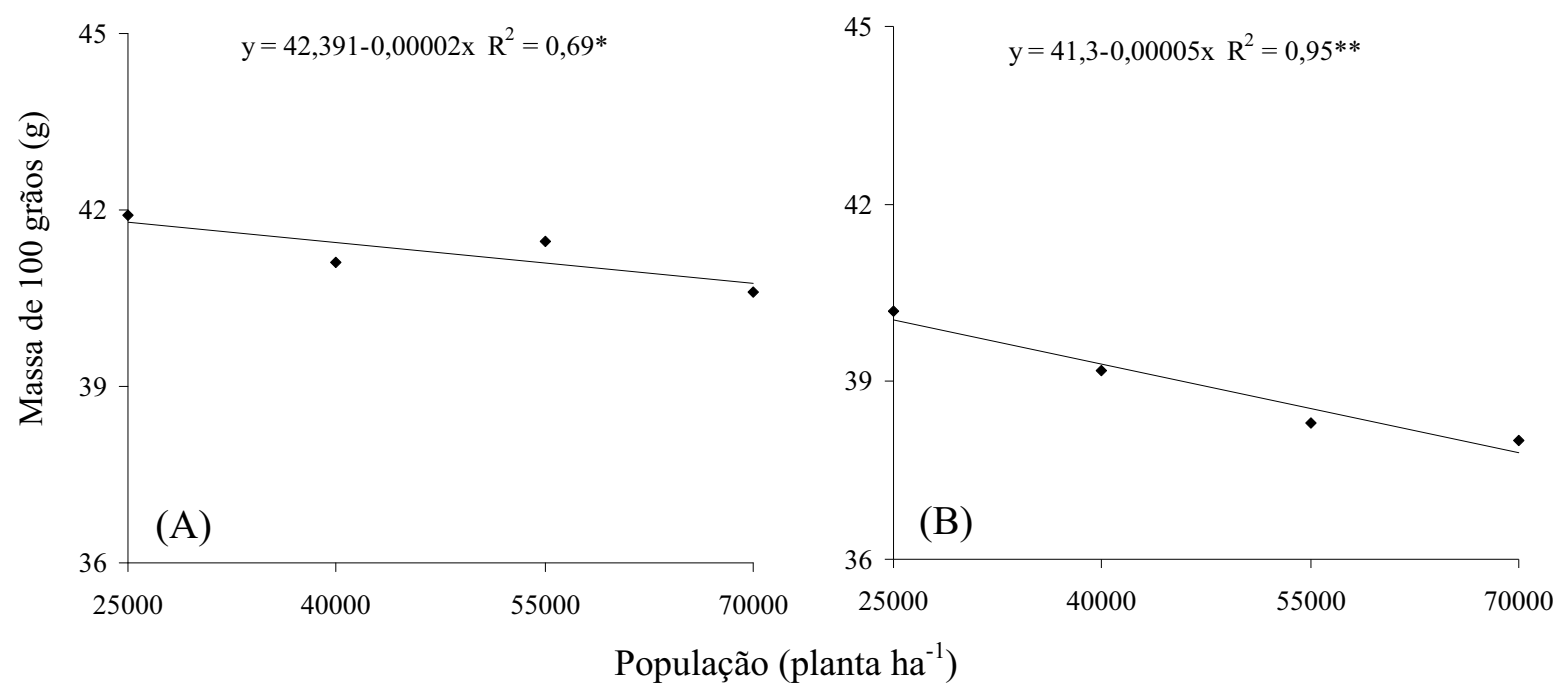

Figura 16. Massa de 100 grãos da cultivar de mamona IAC 2028, em função da população de plantas nas safras de verão 2007/08 (A) e 2008/09 (B). * e ** são significativos a $5 \%$ e $1 \%$ de probabilidade pelo teste $\mathrm{F}$, respectivamente.

A produtividade de grãos da cultivar de mamona IAC 2028 foi influenciada pelo espaçamento entre fileiras e população de plantas, na safra de verão 2007/08 e também pela interação entre os fatores na safra de verão 2008/09 (Tabela 13 ).

Nota-se que nos dois anos agrícolas, o maior espaçamento entre fileiras $(0,90 \mathrm{~m})$ proporcionou a menor produtividade de grãos, independente da população de plantas, enquanto, as maiores produtividades foram obtidas nos espaçamentos menores 
espaçamentos $(0,45,0,60$ e $0,75 \mathrm{~m})$. As maiores produtividades obtidas nos menores espaçamentos se deve à melhor distribuição de plantas, independentemente da população estudada, o que proporcionou a melhor relação entre número de racemos por planta, número de frutos por racemo e número de grãos por fruto. Para Rocha et al. (1964) a aglomeração de plantas na fileira, em função do aumento do espaçamento, promove menor população final de plantas em relação ao inicialmente estabelecido e menor produtividade de grãos. Gondim et al. (2006) verificaram redução da produtividade da cultivar CSRD-142 com aumento do espaçamento entre fileiras, independentemente da população utilizada. Severino et al. (2006a) utilizando a cultivar BRS Nordestina (porte médio), verificaram que espaçamentos mais estreitos entre linhas, proporcionaram maior produtividade em relação os espaçamentos mais largos, indicando que o adensamento populacional poderia ser adotado como forma de aumentar a produtividade.

Na safra de verão 2007/08 o incremento da população de plantas aumentou linearmente a produtividade de grãos (Figura 17A). Efeito semelhante ao observado para a cultivar FCA-PB, ou seja, apesar do aumento da população de plantas ter proporcionado redução na produção de grãos por planta, proporcionou maior produtividade de grãos por área (Figuras 14, 15 e 17), ou seja, a diminuição nos componentes da produção, foi compensado pelo maior número de plantas por área, refletindo em maior produtividade. Gondim et al. (2006) verificaram que a redução do espaçamento e o aumento da população de plantas incrementaram a produtividade da mamoneira. Vale (2009) também obteve aumento linear na produtividade de grãos da cultivar BRS Energia, com aumento da população até 20.000 plantas $\mathrm{ha}^{-1}$.

Na safra de verão 2008/09, o efeito da população de plantas foi observado apenas no espaçamento de $0,75 \mathrm{~m}$ entre fileiras, onde o aumento da população de plantas proporcionou uma redução linear na produtividade de grãos (Figura 17B). Nos espaçamentos de 0,45, 0,60 e 0,90 m entre fileiras, as produtividades médias obtidas foram de $3.402,3.352$ e $2.538 \mathrm{~kg} \mathrm{ha}^{-1}$, respectivamente. Mediante ao observado na Figura 17B, é possível verificar que as maiores produtividades foram obtidas com os arranjos de 0,60 $\mathrm{m} \mathrm{x}$ 40.000 plantas ha ${ }^{-1}$ e $0,45 \mathrm{~m} \times 55.000$ plantas $\mathrm{ha}^{-1}$, com valores acima de $4.000 \mathrm{~kg} \mathrm{ha}^{-1} \mathrm{e}$ semelhantes às maiores produtividades obtidas no primeiro ano do experimento. Tais arranjos provavelmente proporcionaram melhor distribuição das plantas na área e, consequentemente, 
menor competição entre elas. Em experimentos realizados em três locais do Estado de São Paulo (Adamantina, Pindorama e Campinas) e em quatro anos agrícolas, com a cultivar IAC 2028, Savy Filho et al. (2007) verificaram produtividade média de $1.950 \mathrm{~kg} \mathrm{ha}^{-1}$. Os autores ainda relatam que, na safra 2006, o ensaio foi conduzido em safrinha (março a agosto), com disponibilidade hídrica total de $350 \mathrm{~mm}$ mal distribuídos ao longo do ciclo e consideravelmente abaixo das exigências da cultura, que está em torno de $700 \mathrm{~mm}$ (SAVY FILHO, 2005). Mesmo com esta limitação hídrica, a produtividade foi de $1.017 \mathrm{~kg} \mathrm{ha}^{-1}$ (SAVY FILHO et al., 2007). Assim, vale ressaltar que a disponibilidade hídrica total foi de $756 \mathrm{~mm}$, bem distribuída, ao longo de todo o experimento, o que justifica as elevadas produtividades de grãos obtidas nesse trabalho.
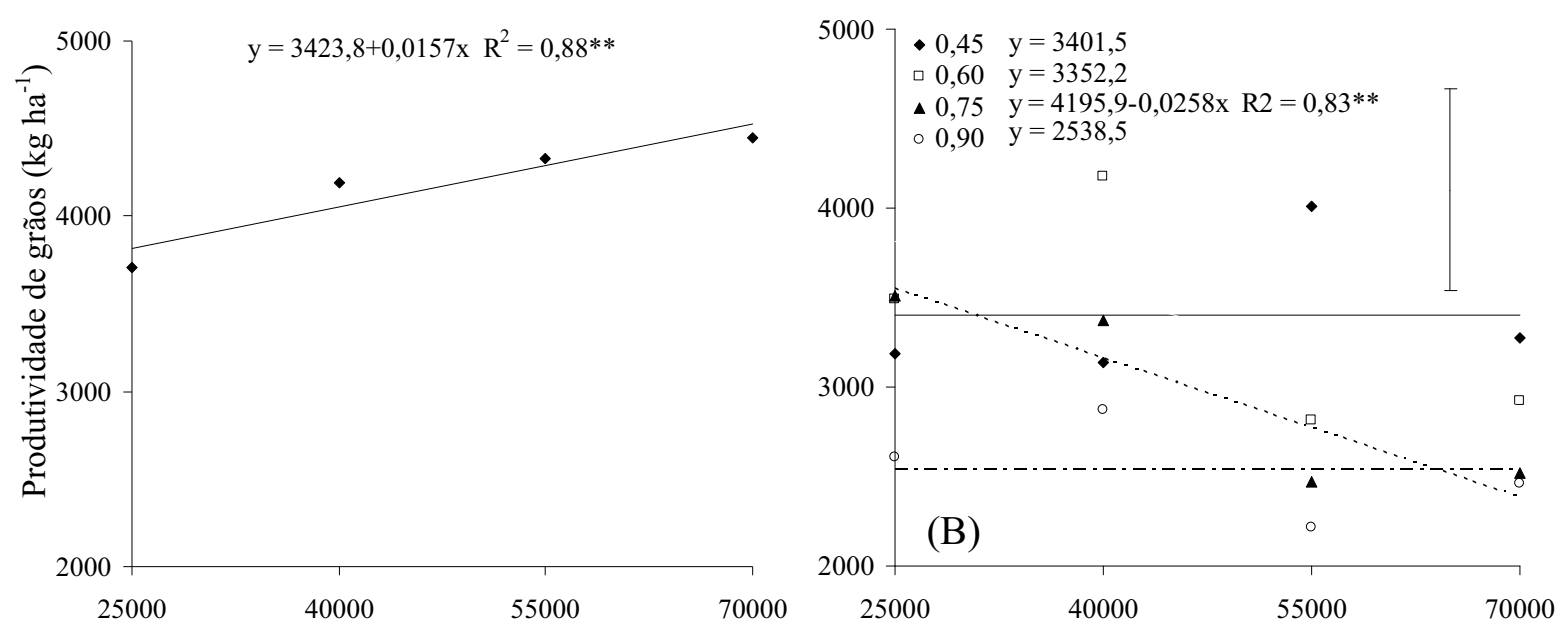

População (planta ha $\left.{ }^{-1}\right)$

Figura 17. Produtividade de grãos da cultivar de mamona IAC 2028 em função da população de plantas, na média de quatro espaçamentos entre fileiras na safra de verão 2007/08 (A) e cada um dos quatro espaçamentos entre fileiras na safra de verão $2008 / 09$ (B). * e ** são significativos a $5 \%$ e $1 \%$ de probabilidade pelo teste $\mathrm{F}$, respectivamente. 
O teor de óleo nos grãos não foi influenciado por nenhum dos fatores estudados (Tabela 14). Cabe destacar que em todos os tratamentos, os teores de óleo foram superiores aos relatados por Savy Filho et al. (2007), para essa cultivar, que foi de 47\%.

Tabela 14. Teor de óleo no grão e produtividade de óleo da cultivar de mamona IAC 2028, nas safras de verão 2007/08 e 2008/09, em função do espaçamento e população de plantas. Botucatu, SP.

\begin{tabular}{|c|c|c|c|c|}
\hline \multirow{2}{*}{ Fontes de variação } & \multicolumn{2}{|c|}{ Teor de óleo no grão } & \multicolumn{2}{|c|}{ Produtividade de óleo } \\
\hline & $2007 / 08$ & $2008 / 09$ & $2007 / 08$ & $2008 / 09$ \\
\hline Espaçamento (m) & \multicolumn{2}{|c|}{$(\%)$} & \multicolumn{2}{|c|}{$\left(\mathrm{kg} \mathrm{ha}^{-1}\right)^{-}$} \\
\hline 0,45 & $49,8 \mathrm{a}^{(1)}$ & $49,3 \mathrm{a}$ & $1.907 \mathrm{a}$ & $1.496 \mathrm{a}$ \\
\hline 0,60 & $49,6 a$ & $50,5 \mathrm{a}$ & $1.830 \mathrm{ab}$ & $1.498 \mathrm{a}$ \\
\hline 0,75 & $50,4 \mathrm{a}$ & $51,3 \mathrm{a}$ & $1.930 \mathrm{a}$ & $1.332 \mathrm{ab}$ \\
\hline 0,90 & $49,7 \mathrm{a}$ & $51,5 \mathrm{a}$ & $1.580 \mathrm{~b}$ & $1.090 \mathrm{~b}$ \\
\hline C.V.(\%) & 5,1 & 4,2 & 15,8 & 23,4 \\
\hline \multicolumn{5}{|l|}{ População (plantas ha ${ }^{-1}$ ) } \\
\hline 25.000 & 50,4 & 50,2 & 1.632 & 1.402 \\
\hline 40.000 & 50,3 & 50,9 & 1.834 & 1.506 \\
\hline 55.000 & 49,5 & 51,1 & 1.865 & 1.283 \\
\hline 70.000 & 49,3 & 50,4 & 1.915 & 1.226 \\
\hline C.V. $(\%)$ & 3,1 & 3,0 & 16,1 & 18,4 \\
\hline \multicolumn{5}{|l|}{ Teste F } \\
\hline Espaçamento (E) & $3,33 \mathrm{~ns}$ & $3,37 \mathrm{~ns}$ & $5,04 *$ & $5,89 *$ \\
\hline \multicolumn{5}{|l|}{ População inicial (P) } \\
\hline Reg. Linear & $1,74 \mathrm{~ns}$ & $0,09 \mathrm{~ns}$ & $7,29 * *$ & $7,23 * *$ \\
\hline Reg. Quadrática & $0,06 \mathrm{~ns}$ & $3,18 \mathrm{~ns}$ & $1,09 \mathrm{~ns}$ & $1,66 \mathrm{~ns}$ \\
\hline $\mathrm{E} \times \mathrm{P}$ & $1,24 \mathrm{~ns}$ & $1,45 \mathrm{~ns}$ & $0,70 \mathrm{~ns}$ & $3,21 * *$ \\
\hline
\end{tabular}

Na safra de verão 2007/08, tanto o espaçamento entre fileiras, quanto a população de plantas influenciaram significativamente a produtividade de óleo (Tabela 14). Em 2008/09, foi constatado também efeito significativo da interação entre os fatores. 
No primeiro ano, os espaçamentos entre fileiras de 0,45 e $0,75 \mathrm{~m}$ proporcionaram as maiores produtividades de óleo (1.919 $\mathrm{kg} \mathrm{ha}^{-1}$ em média), diferindo do espaçamento de $0,90 \mathrm{~m}$, que proporcionou produtividade de óleo de $1.580 \mathrm{~kg} \mathrm{ha}^{-1}$. No segundo ano, os menores espaçamentos $(0,45$ e $0,60 \mathrm{~m})$ proporcionaram as maiores produtividade de óleo, diferindo significativamente do espaçamento de $0,90 \mathrm{~m}$.

A produtividade de óleo, na safra de verão 2007/08, aumentou linearmente com o incremento da população de plantas (Figura 18A), efeito semelhante ao observado para a produtividade de grãos (Figura 17A), esse fator explica o resultado positivo dessa variável, pois estão diretamente relacionados. Na safra de verão 2008/09, a produtividade de óleo foi influenciada pela interação espaçamento x população de plantas (Figura 18B). A produtividade de óleo foi reduzida linearmente com o aumento da população de plantas nos espaçamentos de $0,75 \mathrm{~m}$. Já nos demais espaçamentos, não foram observados efeitos da população de plantas. As maiores produtividades de óleo foram obtidas com os

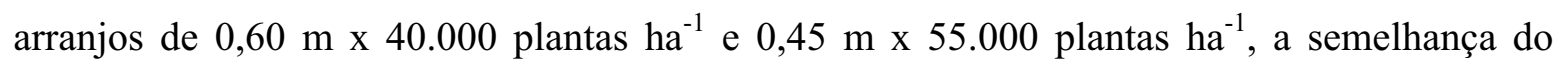
observado para a produtividade de grãos.
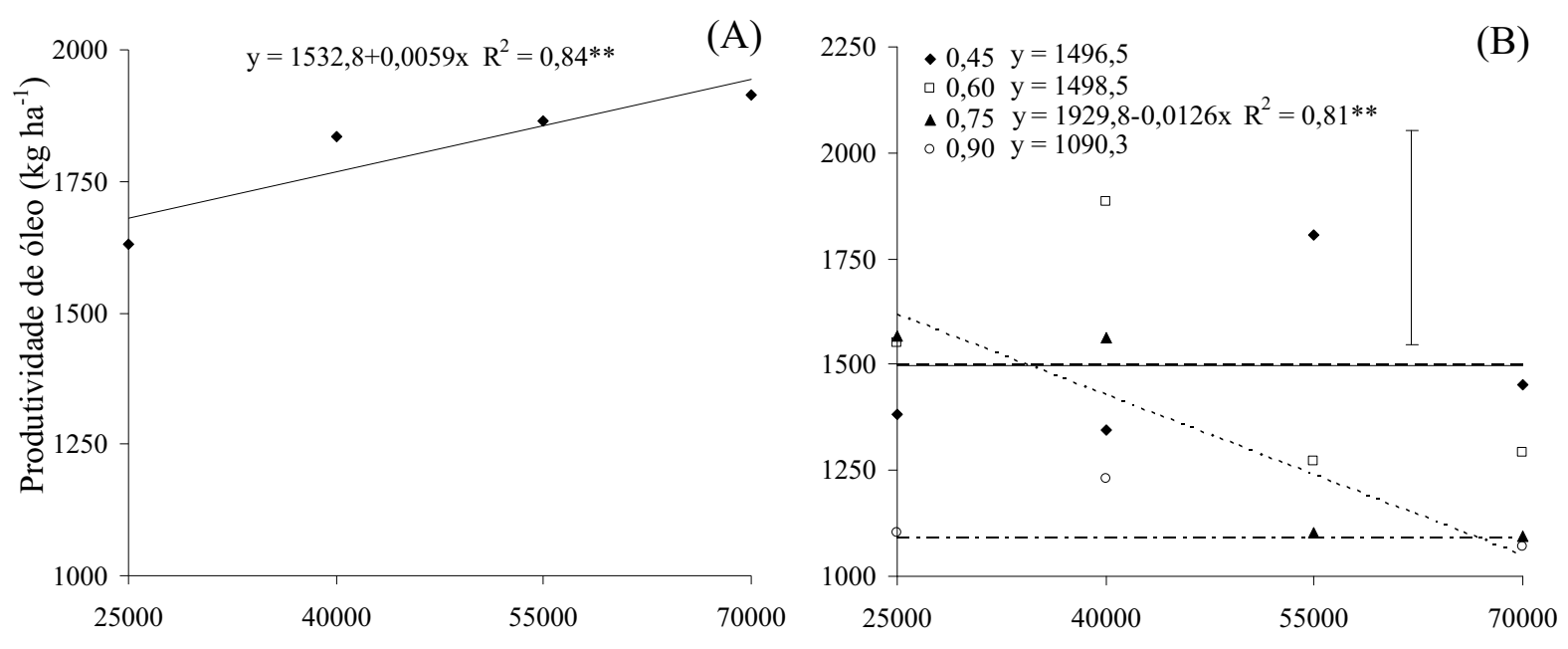

População (planta ha ${ }^{-1}$ )

Figura 18. Produtividade de óleo da cultivar de mamona IAC 2028 em função da população de plantas, na média de quatro espaçamentos entre fileiras na safra de verão 2007/08 (A) e cada um dos quatro espaçamentos entre fileiras na safra de verão 2008/09 (B). ** é significativo e 1\% de probabilidade pelo teste $\mathrm{F}$. 


\subsection{Experimentos da Safrinha (2008 e 2009)}

\subsubsection{Cultivar FCA-PB}

Nos tratamentos com populações mais adensadas notou-se ligeira redução na população final, quando comparadas com as populações previamente estabelecidas (Tabela 15). Provavelmente, em condições mais adensadas, as plantas mais fracas tiveram menor condição de competir durante o crescimento e morreram antes da colheita, enquanto em situação de menor densidade, estas conseguiram sobreviver. Esta inferência vem explicar a maior diferença entre as populações inicias e na colheita, observadas nas maiores populações, independentemente do espaçamento.

Tabela 15. População final de plantas obtida na colheita da mamona cultivar FCA-PB em função do espaçamento entre fileiras e da população inicial de plantas, nas safrinhas 2008 e 2009. Botucatu - SP.

\begin{tabular}{|c|c|c|c|c|c|}
\hline \multirow{2}{*}{ População inicial } & \multicolumn{4}{|c|}{ Espaçamento (m) } & \multirow{2}{*}{ Média } \\
\hline & 0,45 & 0,60 & 0,75 & 0,90 & \\
\hline \multicolumn{6}{|c|}{ - $\left(\right.$ plantas ha $\left.^{-1}\right)$} \\
\hline \multicolumn{6}{|c|}{ Safrinha 2008} \\
\hline 25.000 & 25.000 & 25.000 & 25.000 & 25.000 & $25.000(100 \%)^{(1)}$ \\
\hline 40.000 & 40.000 & 39.690 & 40.000 & 38.241 & $39.483(97,7 \%)$ \\
\hline 55.000 & 55.000 & 54.028 & 53.750 & 50.927 & $53.426(97,1 \%)$ \\
\hline 70.000 & 70.000 & 67.361 & 64.200 & 60.648 & $65.552(93,7 \%)$ \\
\hline \multicolumn{6}{|c|}{ Safrinha 2009} \\
\hline 25.000 & 25.000 & 25.000 & 24.861 & 24.957 & $24.954(99,8 \%)$ \\
\hline 40.000 & 40.000 & 37.537 & 39.889 & 39.880 & $39.326(98,3 \%)$ \\
\hline 55.000 & 55.000 & 52.083 & 54.861 & 52.778 & $53.680(97,6 \%)$ \\
\hline 70.000 & 68.583 & 65.972 & 65.555 & 63.426 & $65.884(94,1 \%)$ \\
\hline
\end{tabular}

De acordo com Rocha et al. (1964), o adensamento das plantas na fileira reduz a população final, devido a maior competição intra-específica, por água, luz e nutrientes. Segundo Beltrão et al. (2007), os principais componentes da produção, para 
cultivares de porte baixo a médio e de ciclo médio, são os números de racemos por planta e o número de frutos por racemo; no entanto, para os híbridos de baixo porte, a população de plantas $\mathrm{ha}^{-1}$ é uma característica que assume grande importância, pois, em altas populações (superiores a 50 mil plantas $\mathrm{ha}^{-1}$ ) os híbridos produzem somente dois racemos por planta. Nesse raciocínio, é possível inferir que em elevadas populações, também para cultivares, o número de plantas por área assume grande importância entre os componentes da produção, já que estas produzem número de racemos por planta relativamente menor.

Nas duas safrinhas (2008 e 2009), constatou-se que a matéria seca da parte aérea foi influenciada pelo espaçamento entre fileiras e pela população de plantas, no entanto, na safrinha 2008, também foi observado efeito da interação entre os fatores (Tabela 16).

Em 2008, as maiores massas de matéria seca foram verificadas no espaçamento de 0,45 e $0,75 \mathrm{~m}$ entre fileiras, sendo em média $26,9 \%$ superior as observadas nos espaçamentos de 0,60 e 0,90 m (Tabela 16). Já na safrinha 2009, o espaçamento entre fileiras que proporcionou a maior massa de matéria seca foi o de $0,75 \mathrm{~m}$, com valor médio de $36,2 \mathrm{~g}$, porém, diferindo apenas do espaçamento de 0,60 m, que teve produção de 27,4 g, ou seja, $24,3 \%$ menor.

O aumento da população de plantas reduziu linearmente a massa de matéria seca por planta, independente dos espaçamentos entre fileiras empregados (Figura 19). Contudo, no primeiro ano, os efeitos foram mais pronunciados nos espaçamentos de 0,60 e $0,75 \mathrm{~m}$ entre fileiras, o que está relacionado com a alteração na distribuição das plantas na área (Tabela 2). Comportamento semelhante foi observado para essa cultivar nas safras de verão.

Vale ressaltar que a mamona é altamente influenciada pelos fatores luz, água, nutriente e temperatura (BELTRÃO et al., 2007b), os quais foram diferentes entre as safrinhas estudadas (Figura 1 e 2). Isso pode explicar a maior produção de matéria seca na safrinha 2009, em relação à safrinha 2008. 
Tabela 16. Matéria seca da parte aérea e diâmetro do caule da cultivar de mamona FCA-PB, nas safrinhas 2008 e 2009 , em função do espaçamento e população de plantas. Botucatu, SP.

\begin{tabular}{|c|c|c|c|c|}
\hline \multirow{2}{*}{ Fontes de variação } & \multicolumn{2}{|c|}{ Matéria seca da parte aérea } & \multicolumn{2}{|c|}{ Diâmetro do caule } \\
\hline & 2008 & 2009 & 2008 & 2009 \\
\hline Espaçamento (m) & \multicolumn{2}{|c|}{$\left(\right.$ g planta $\left.^{-1}\right)$} & \multicolumn{2}{|c|}{$(\mathrm{mm})^{-}$} \\
\hline 0,45 & $25,2 \mathrm{a}^{(1)}$ & $36,0 \mathrm{ab}$ & $21,3 \mathrm{a}$ & $19,6 \mathrm{a}$ \\
\hline 0,60 & $19,8 b$ & $27,4 b$ & $19,8 b$ & $19,5 \mathrm{a}$ \\
\hline 0,75 & $24,8 \mathrm{a}$ & $36,2 \mathrm{a}$ & $20,9 a$ & $19,2 \mathrm{a}$ \\
\hline 0,90 & $19,6 b$ & $34,0 \mathrm{ab}$ & $18,6 \mathrm{c}$ & $19,5 \mathrm{a}$ \\
\hline C.V.(\%) & 9,01 & 23,9 & 4,4 & 3,9 \\
\hline \multicolumn{5}{|l|}{ População (plantas ha- ${ }^{-1}$ ) } \\
\hline 25.000 & 24,1 & 40,7 & 22,5 & 22,3 \\
\hline 40.000 & 23,1 & 34,7 & 20,3 & 19,7 \\
\hline 55.000 & 21,3 & 31,8 & 19,1 & 17,7 \\
\hline 70.000 & 18,0 & 26,5 & 18,7 & 18,1 \\
\hline C.V. $(\%)$ & 10,1 & 20,7 & 7,0 & 4,3 \\
\hline \multicolumn{5}{|l|}{ Teste $\mathrm{F}$} \\
\hline Espaçamento (E) & $36,39 * *$ & $4,210^{*}$ & $29,39 * *$ & $1,16 \mathrm{~ns}$ \\
\hline \multicolumn{5}{|l|}{ População inicial (P) } \\
\hline Reg. Linear & $133,83 * *$ & $34,46 * *$ & $65,43 * *$ & $251,32 * *$ \\
\hline Reg. Quadrática & $0,44 \mathrm{~ns}$ & $0,06 \mathrm{~ns}$ & $5,87^{*}$ & $54,68^{* *}$ \\
\hline$E \times P$ & $3,11 * *$ & $0,35 \mathrm{~ns}$ & $2,52 *$ & $3,18^{* *}$ \\
\hline
\end{tabular}

(1) Médias seguidas de letras distintas, na coluna, dentro do fator espaçamento, diferem estatisticamente pelo teste de Tukey a $5 \%$ de probabilidade. $*, * *$ e ns são, respectivamente, significativos a $5 \%, 1 \%$ de probabilidade e não-significativo pelo teste $\mathrm{F}$.

O diâmetro do caule, na safrinha 2008, foi influenciado pelo espaçamento entre fileiras, população de plantas e interação entre eles (Tabela 16). Já na safrinha 2009, foi observada a influência da população e da interação espaçamento $x$ população de plantas. 
Em 2008, pode-se observar que os maiores diâmetros caulinares foram proporcionados pelos espaçamentos de 0,45 e 0,75 m entre fileiras (Tabela 16), semelhante ao observado para a matéria seca da parte aérea. Mediante a Figura 20A, constatase que, principalmente na menor população de plantas, o espaçamento de $0,90 \mathrm{~m}$ entre fileiras, proporcionou diâmetro caulinar menor que os demais espaçamentos.

$\mathrm{O}$ aumento da população de plantas reduziu significativamente o diâmetro do caule em todos os espaçamentos (Figura 20), com exceção do espaçamento de 0,90 m entre fileiras, na safra 2008, no qual as plantas não foram afetadas. Esses resultados corroboram com Vale (2009), que utilizando a cultivar BRS Energia, também observou decréscimo no diâmetro do caule com o aumento da população de plantas. $\mathrm{O}$ autor justifica que esse efeito foi em função da maior competição intra-especifica pelos fatores limitantes ao crescimento e desenvolvimento tais como, água, luz e nutrientes. O que também pode explicar os resultados desse trabalho.
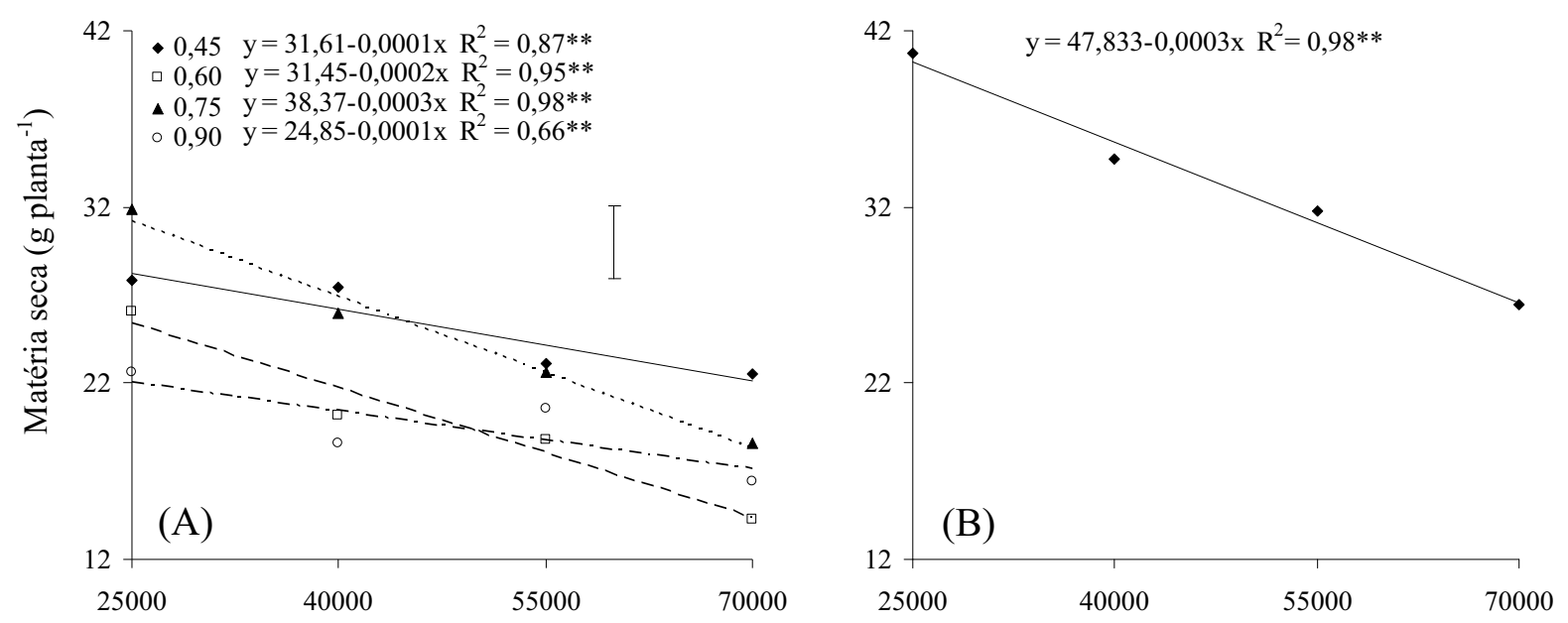

População (planta ha $\left.{ }^{-1}\right)$

Figura 19. Matéria seca da parte aérea da cultivar de mamona FCA-PB em função dos quatro espaçamentos entre fileiras na safrinha 2008 (A) e da população de plantas, na média de quatro espaçamentos entre fileiras na safrinha 2009 (B). ** é significativo a $1 \%$ de probabilidade pelo teste $\mathrm{F}$. 

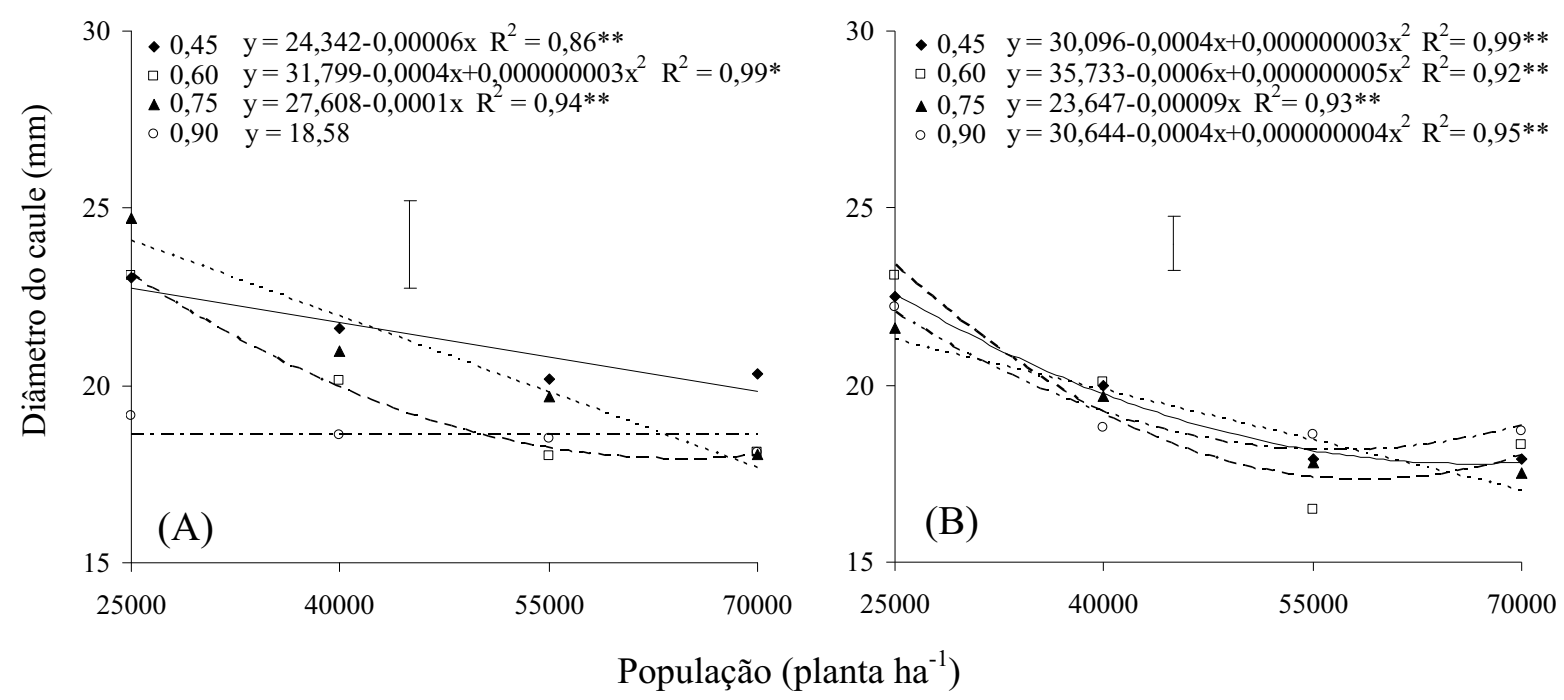

Figura 20. Diâmetro do caule da cultivar de mamona FCA-PB em função da população de plantas e do espaçamento entre fileiras nas safrinhas 2008 (A) e 2009 (B). * e ** são significativos a $5 \%$ e $1 \%$ de probabilidade pelo teste $\mathrm{F}$, respectivamente.

O espaçamento entre plantas e a interação espaçamento x população de plantas influenciaram significativamente a altura de planta, na safrinha 2008 (Tabela 17). Porém, na safrinha 2009, foram observados os efeitos de todos os fatores e da interação entre eles. A maior altura de planta $(1,14 \mathrm{~m})$, na safrinha 2008 , foi verificada no espaçamento de $0,45 \mathrm{~m}$ entre fileiras, diferindo apenas do maior espaçamento $(0,90 \mathrm{~m})$, que apresentou valor médio de 1,03 m. Já na safrinha 2009, os maiores valores de altura de planta (1,23 e 1,26 m) foram observados nos maiores espaçamentos $(0,75$ e $0,90 \mathrm{~m})$. Gondim et al. (2006) não verificaram influência do espaçamento entre fileira e do adensamento na fileira na altura das plantas da cultivar CSRN-142, em condições de sequeiro. Porém, Vale (2009) observou aumento linear na altura de planta com a redução do espaçamento entre fileiras e o aumento na população de plantas na área. 
Tabela 17. Altura da planta e de inserção do primeiro racemo da cultivar de mamona FCAPB, nas safrinhas 2008 e 2009, em função do espaçamento e população de plantas. Botucatu, SP.

\begin{tabular}{|c|c|c|c|c|}
\hline \multirow[t]{2}{*}{ Fontes de variação } & \multicolumn{2}{|c|}{$\begin{array}{l}\text { Altura de } \\
\text { planta }\end{array}$} & \multicolumn{2}{|c|}{$\begin{array}{c}\text { Altura de inserção } \\
\text { do } 1^{\underline{o}} \text { racemo }\end{array}$} \\
\hline & 2008 & 2009 & 2008 & 2009 \\
\hline Espaçamento (m) & 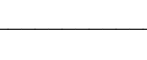 & 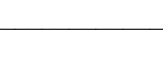 & 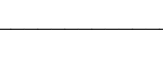 & 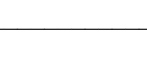 \\
\hline 0,45 & $1,14 \mathrm{a}^{(1)}$ & $1,18 b$ & $0,39 a$ & $0,41 \mathrm{ab}$ \\
\hline 0,60 & $1,07 \mathrm{ab}$ & $1,10 \mathrm{c}$ & $0,35 b$ & $0,40 \mathrm{~b}$ \\
\hline 0,75 & $1,11 \mathrm{ab}$ & $1,23 \mathrm{ab}$ & $0,36 b$ & $0,42 \mathrm{ab}$ \\
\hline 0,90 & $1,03 b$ & $1,26 \mathrm{a}$ & $0,34 b$ & $0,48 \mathrm{a}$ \\
\hline C.V.(\%) & 8,0 & 4,6 & 4,2 & 15,0 \\
\hline \multicolumn{5}{|l|}{ População (plantas ha ${ }^{-1}$ ) } \\
\hline 25.000 & 1,09 & 1,23 & 0,34 & 0,37 \\
\hline 40.000 & 1,07 & 1,20 & 0,35 & 0,40 \\
\hline 55.000 & 1,10 & 1,15 & 0,38 & 0,45 \\
\hline 70.000 & 1,10 & 1,20 & 0,38 & 0,49 \\
\hline C.V. $(\%)$ & 7,0 & 5,4 & 6,9 & 16,4 \\
\hline \multicolumn{5}{|l|}{ Teste F } \\
\hline Espaçamento (E) & $5,01^{*}$ & $26,09 * *$ & $27,45 * *$ & $4,72 *$ \\
\hline \multicolumn{5}{|l|}{ População inicial (P) } \\
\hline Reg. Linear & $0,32 \mathrm{~ns}$ & $3,83 \mathrm{~ns}$ & $28,32 * *$ & $30,10 * *$ \\
\hline Reg. Quadrática & $0,15 \mathrm{~ns}$ & $5,36^{*}$ & $0,01 \mathrm{~ns}$ & $0,15 \mathrm{~ns}$ \\
\hline $\mathrm{E} \times \mathrm{P}$ & $2,55^{*}$ & $10,23 * *$ & $2,99 * *$ & $1,62 \mathrm{~ns}$ \\
\hline
\end{tabular}

Na safrinha 2008, o incremento da população de plantas aumentou a altura das plantas que se encontravam no maior espaçamento entre fileiras $(0,90 \mathrm{~m})$, porém, nos demais espaçamentos a altura das plantas não foram afetadas (Figura 21A).

Em 2009, verificou-se que a altura de planta foi reduzida nos menores espaçamentos $(0,45$ e $0,60 \mathrm{~m})$ e aumentada nos maiores $(0,75$ e $0,90 \mathrm{~m})$, com o incremento da população de plantas. Os resultados divergiram entre os anos e discordam de Kittock e Williams (1970), pois, os autores verificaram que a altura das plantas de híbridos de mamona 
de porte anão não é alterada com adensamento de plantas na fileira. Já, Ferreira et al. (2006) relatam que o plantio adensado aumenta a competição por água e nutrientes, reduzindo o crescimento das plantas. De acordo com Severino et al. (2006a), a altura da mamoneira está diretamente relacionada à disponibilidade de água durante o ciclo e à competição por luz. Por esse motivo, o estreitamento do espaçamento entre linhas tanto pode reduzir a altura das plantas, quando a disponibilidade de água é baixa, quanto provocar aumento do porte das plantas, quando há adequado suprimento hídrico, pois o excessivo crescimento lateral das plantas provoca aumento na competição por luz, o que pode por induzir ao maior crescimento em altura.
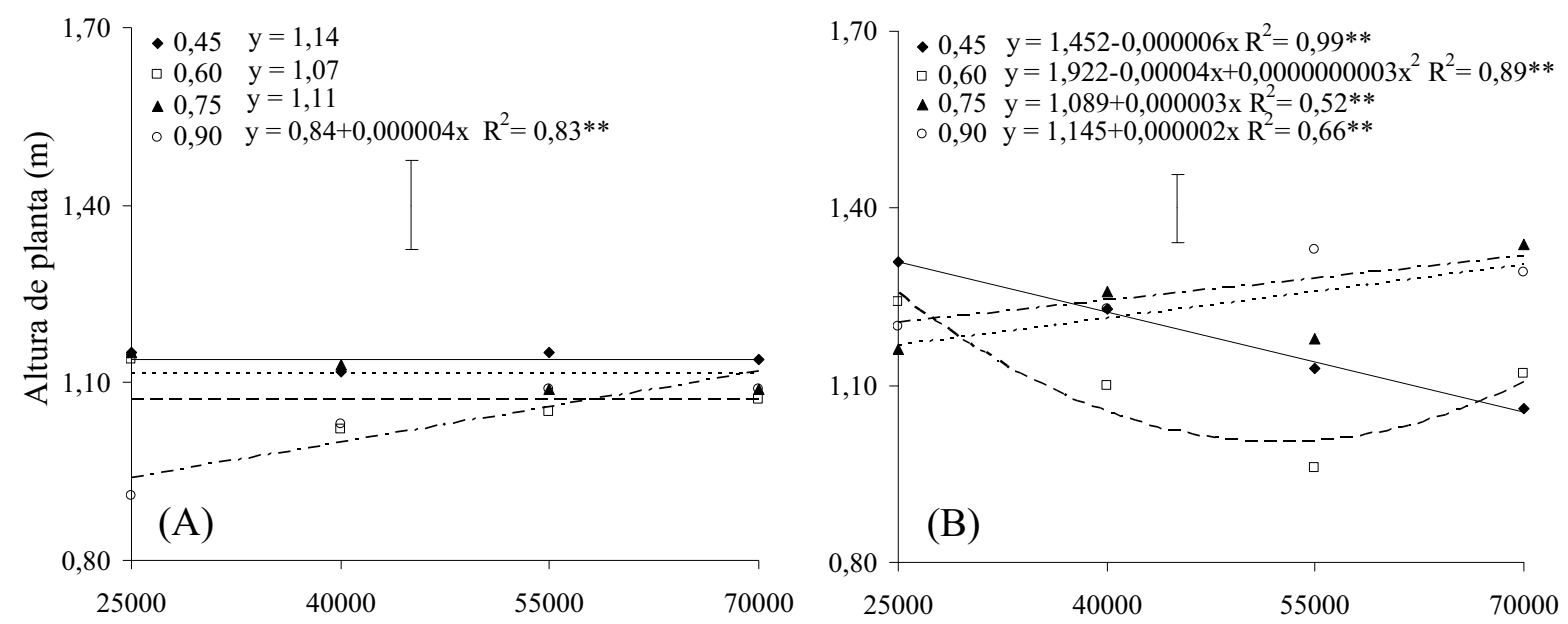

População (planta ha' $\left.{ }^{-1}\right)$

Figura 21. Altura de plantas da cultivar de mamona FCA-PB em função da população de plantas e do espaçamento entre fileiras nas safrinhas 2008 (A) e 2009 (B). ** é significativo a $1 \%$ de probabilidade pelo teste $\mathrm{F}$.

Em 2008, a altura de inserção do primeiro racemo foi influenciada pelo espaçamento entre fileiras, população de plantas e, a interação entre os fatores, enquanto, na safrinha 2009 os fatores afetaram essa variável de forma isolada (Tabela 17 e Figura 22).

$\mathrm{Na}$ safrinha 2008, a maior altura de inserção do primeiro racemo $(0,39$ m) foi observado no espaçamento de $0,45 \mathrm{~m}$ entre fileiras, diferindo dos demais, que apresentaram valor médio de 0,35 m. Segundo Severino et al. (2006a), as alterações na altura de inserção do primeiro racemo pode indicar que o estreitamento do espaçamento entre fileiras proporcionou maior crescimento das plantas provavelmente pela maior competição por luz. 
No segundo ano, a menor altura de inserção do primeiro racemo foi constatada no espaçamento de $0,60 \mathrm{~m}$, diferindo significativamente apenas do espaçamento de $0,90 \mathrm{~m}$, que apresentou a maior altura $(0,48 \mathrm{~m})$. Esses resultados estão associados com a altura de plantas, ou seja, plantas mais altas resultaram em maiores alturas de inserção do primeiro racemo. O estreitamento do espaçamento entre fileiras, pode reduzir a altura das plantas e de inserção do primeiro racemo, quando a disponibilidade de água é baixa, como observado na safrinha 2008 (Figura 1). Porém, pode provocar aumento do porte das plantas e na altura de inserção do primeiro racemo, quando o suprimento hídrico é maior, pois o excessivo crescimento lateral das plantas provoca aumento na competição por luz, o que pode por induzir ao maior crescimento em altura, o que pode ter ocorrido na safrinha 2009 (Figura 2) (SEVERINO et al., 2006a).

Por meio da interação significativa entre o espaçamento $\mathrm{x}$ população de plantas (safrinha 2008) verificou-se que o aumento da população de plantas proporcionou incremento da altura de inserção do primeiro racemo nos maiores espaçamentos $(0,75$ e 0,90 m) entre fileiras, mas não alterou essa variável nos menores espaçamentos (Figura 22A). Esse resultado indica que nos espaçamentos entre fileiras mais largos, ocorre maior competição entre plantas na fileira, devido ao maior adensamento. Na safrinha 2009, pode-se observar um aumento linear na altura de inserção do primeiro racemo com o incremento da população de plantas, independente do espaçamento entre fileiras, provavelmente devido a maior disponibilidade hídrica e, consequentemente, maior crescimento das plantas (Figuras 1, 2 e 22B). Silva et al. (2006) estudando os efeitos de três espaçamentos entre fileiras $(0,38 ; 0,76$ e $0,95 \mathrm{~m})$ e quatro populações de planas $\left(5,8,11 \mathrm{e} 14\right.$ plantas $\mathrm{m}^{-1}$ linear), para a cultura do algodoeiro, não constataram interação significativa entre espaçamento e densidade para a inserção do primeiro ramo frutífero, mas observaram efeito das densidades estudadas, sendo superior estatisticamente na densidade de 14 plantas $\mathrm{m}^{-1}$. 


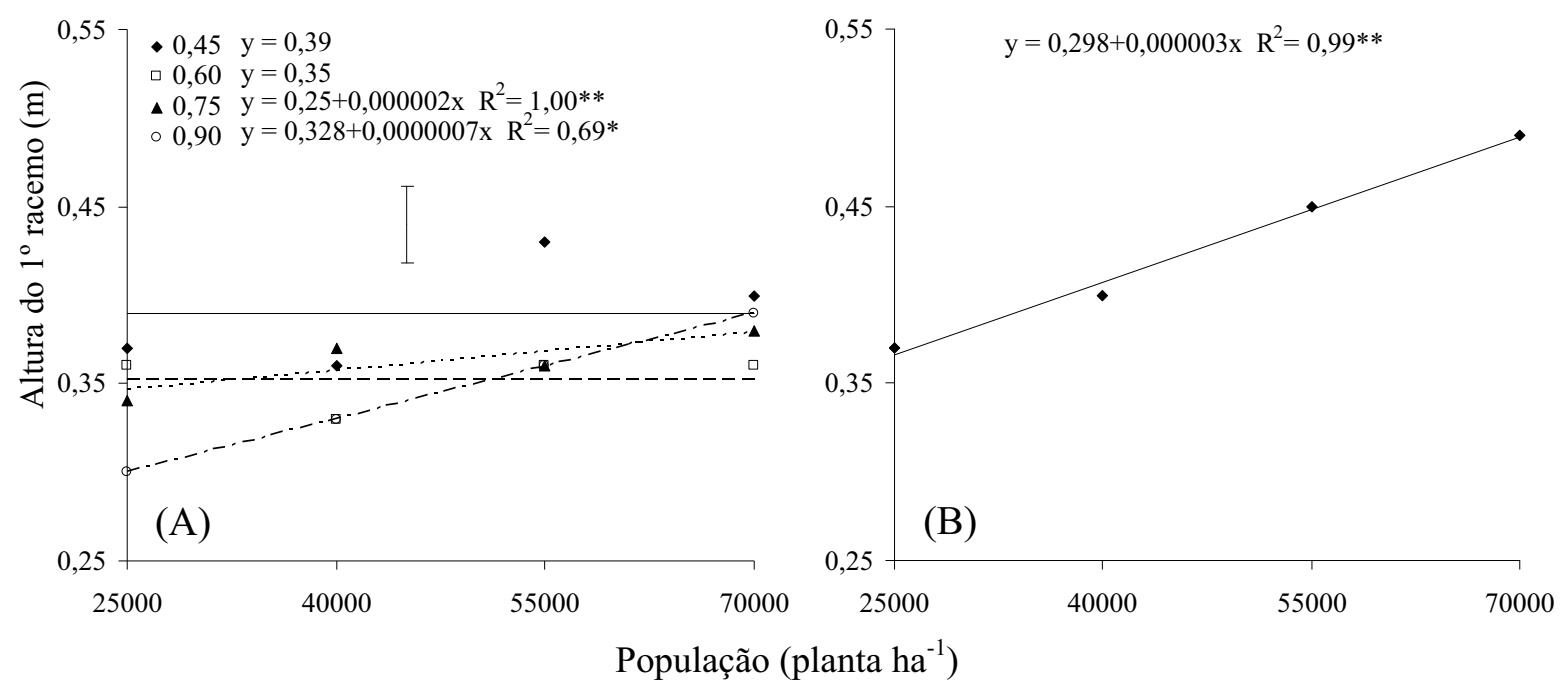

Figura 22. Altura de inserção do primeiro racemo da cultivar de mamona FCA-PB em função dos quatro espaçamentos entre fileiras na safrinha 2008 (A) e da população de plantas, na média de quatro espaçamentos entre fileiras na safrinha 2009 (B). * e ** são significativos a $5 \%$ e $1 \%$ de probabilidade pelo teste $\mathrm{F}$, respectivamente.

Mesmo com a redução na matéria seca e porte das plantas cultivadas no maior espaçamento entre fileiras, na safrinha 2008 não foi observado alteração no número racemos produzidos por planta (Tabela 16, 17 e 18). Em 2009, constatou-se que o espaçamento entre fileiras de $0,75 \mathrm{~m}$ proporcionou o maior número de racemos por planta $(3,1)$.

Nos dois anos de cultivo, aumento na população da plantas reduziu significativamente o número de racemos por planta, em todos os espaçamentos estudados (Figura 23), sendo essa redução mais pronunciada na safrinha 2009. Esses resultados são concordantes com Gondim et al. (2006) que também verificaram que o número de racemos por planta da cultivar de mamona CSRN-142 foi reduzido com o aumento da população de plantas na fileira. O mesmo efeito também foi observado por Vale (2009), para a cultivar BRS Energia. Ainda analisando a Figura 23B, nota-se que, principalmente nas menores populações, os espaçamentos entre fileiras mais estreitos proporcionaram os maiores números de racemos por planta. Essa diferença é explicada pela melhor distribuição das plantas na área, ou seja, melhor arranjo espacial (Tabela 2). 
Na safrinha 2008, o número de frutos por racemo foi influenciado significativamente pelo espaçamento entre fileiras e população de plantas (Tabela 18). Em 2009, foi constatado efeito dos fatores e da interação entre eles.

Em 2008, os menores espaçamentos entre fileiras promoveram maiores valores de frutos por racemo (Tabela 18). Já, em 2009, o espaçamento que proporcionou o menor valor dessa variável foi o de $0,60 \mathrm{~m}$ entre fileiras, diferindo significativamente dos demais.

Tabela 18. Número de racemos por planta, frutos por racemo e grãos por fruto da cultivar de mamona FCA-PB, nas safrinhas 2008 e 2009, em função do espaçamento e população de plantas. Botucatu, SP.

\begin{tabular}{|c|c|c|c|c|c|c|}
\hline \multirow[t]{2}{*}{ Fontes de variação } & \multicolumn{2}{|c|}{$\begin{array}{c}\text { № de racemos por } \\
\text { planta }\end{array}$} & \multicolumn{2}{|c|}{$\begin{array}{l}\mathrm{N}^{\mathrm{o}} \text { de frutos por } \\
\text { racemo }\end{array}$} & \multicolumn{2}{|c|}{$\begin{array}{l}\mathrm{N}^{\mathrm{o}} \text { de grãos por } \\
\text { fruto }\end{array}$} \\
\hline & 2008 & 2009 & 2008 & 2009 & 2008 & 2009 \\
\hline Espaçamento (m) & \multicolumn{2}{|c|}{$\left(\right.$ racemos planta $\left.^{-1}\right)$} & \multicolumn{2}{|c|}{ (frutos racemo $^{-1}$ ) } & \multicolumn{2}{|c|}{ (grãos fruto $^{-1}$ ) } \\
\hline 0,45 & $2,4 \mathrm{a}^{(1)}$ & $2,6 b$ & $22,8 \mathrm{a}$ & $14,0 \mathrm{a}$ & $2,0 \mathrm{~b}$ & $2,9 a$ \\
\hline 0,60 & $2,4 a$ & $2,5 \mathrm{c}$ & $22,0 \mathrm{a}$ & $12,3 b$ & $2,2 \mathrm{a}$ & $2,8 \mathrm{a}$ \\
\hline 0,75 & $2,4 a$ & $3,1 \mathrm{a}$ & $21,7 \mathrm{ab}$ & $14,2 \mathrm{a}$ & $2,3 a$ & $2,9 a$ \\
\hline 0,90 & $2,3 a$ & $2,3 \mathrm{c}$ & $20,7 b$ & $14,4 \mathrm{a}$ & $2,3 a$ & $2,9 a$ \\
\hline C.V.(\%) & 7,0 & 8,6 & 4,6 & 5,1 & 5,8 & 3,4 \\
\hline \multicolumn{7}{|l|}{ População (plantas ha ${ }^{-1}$ ) } \\
\hline 25.000 & 3,0 & 3,6 & 27,2 & 15,0 & 2,2 & 2,8 \\
\hline 40.000 & 2,5 & 2,9 & 22,1 & 14,3 & 2,4 & 2,9 \\
\hline 55.000 & 2,2 & 2,1 & 20,0 & 13,1 & 2,1 & 2,9 \\
\hline 70.000 & 1,9 & 1,9 & 18,0 & 12,5 & 2,1 & 2,9 \\
\hline C.V.(\%) & 5,8 & 7,0 & 12,5 & 5,2 & 9,4 & 3,1 \\
\hline \multicolumn{7}{|l|}{ Teste F } \\
\hline Espaçamento (E) & $2,56 \mathrm{~ns}$ & $37,61 * *$ & $11,29 * *$ & $29,28 * *$ & $20,15 * *$ & $3,45 \mathrm{~ns}$ \\
\hline \multicolumn{7}{|l|}{ População inicial (P) } \\
\hline Reg. Linear & $513,34 * *$ & $829,39 * *$ & $95,78 * *$ & $119,58^{* *}$ & $1,56 \mathrm{~ns}$ & $5,45 \mathrm{~ns}$ \\
\hline Reg. Quadrática & $16,18 * *$ & $34,77 * *$ & $5,19 *$ & $0,12 \mathrm{~ns}$ & $2,88 \mathrm{~ns}$ & $0,10 \mathrm{~ns}$ \\
\hline $\mathrm{E} \times \mathrm{P}$ & $4,24 * *$ & $7,19 * *$ & $1,26 \mathrm{~ns}$ & $7,62 * *$ & $3,66^{* *}$ & $0,83 \mathrm{~ns}$ \\
\hline
\end{tabular}

${ }^{(1)}$ Médias seguidas de letras distintas, na coluna, dentro do fator espaçamento, diferem estatisticamente pelo teste de Tukey a $5 \%$ de probabilidade. ${ }^{*},{ }^{* *}$ e ns são, respectivamente, significativos a $5 \%, 1 \%$ de probabilidade e nãosignificativo pelo teste $\mathrm{F}$. 
O número de frutos por racemo foi reduzido linearmente com o incremento da população de plantas, independente do espaçamento entre fileiras, na safrinha

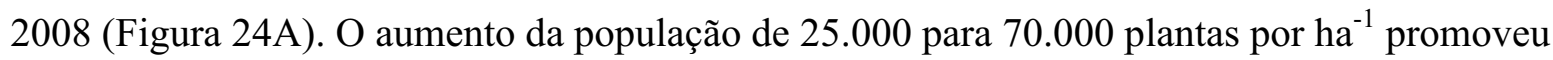
decréscimo de 33,8\% no número de frutos por racemo. Na interação entre os fatores, o mesmo efeito negativo do aumento da população de plantas foi observado para os espaçamentos de 0,60, 0,75 e 0,90 m entre fileiras, porém, no menor espaçamento, não houve influência, devido a melhor distribuição das plantas na área e, consequentemente, menor competição por luz, água e nutrientes entre as plantas. É importante salientar que o valor médio de frutos por racemo, na safrinha 2008, foram maiores do que os obtidos em 2009 (Figura 24). Esse fato pode estar relacionado com o maior volume de chuva ocorrido na safrinha 2009 (Figuras 1 e 2), pois, Souza e Távora (2006) constataram que, em condições de alta disponibilidade de água e nutrientes, a mamoneira retardou o florescimento e a frutificação, tendo maior crescimento vegetativo, o que pode explicar, em parte, os resultados observados nesse trabalho.

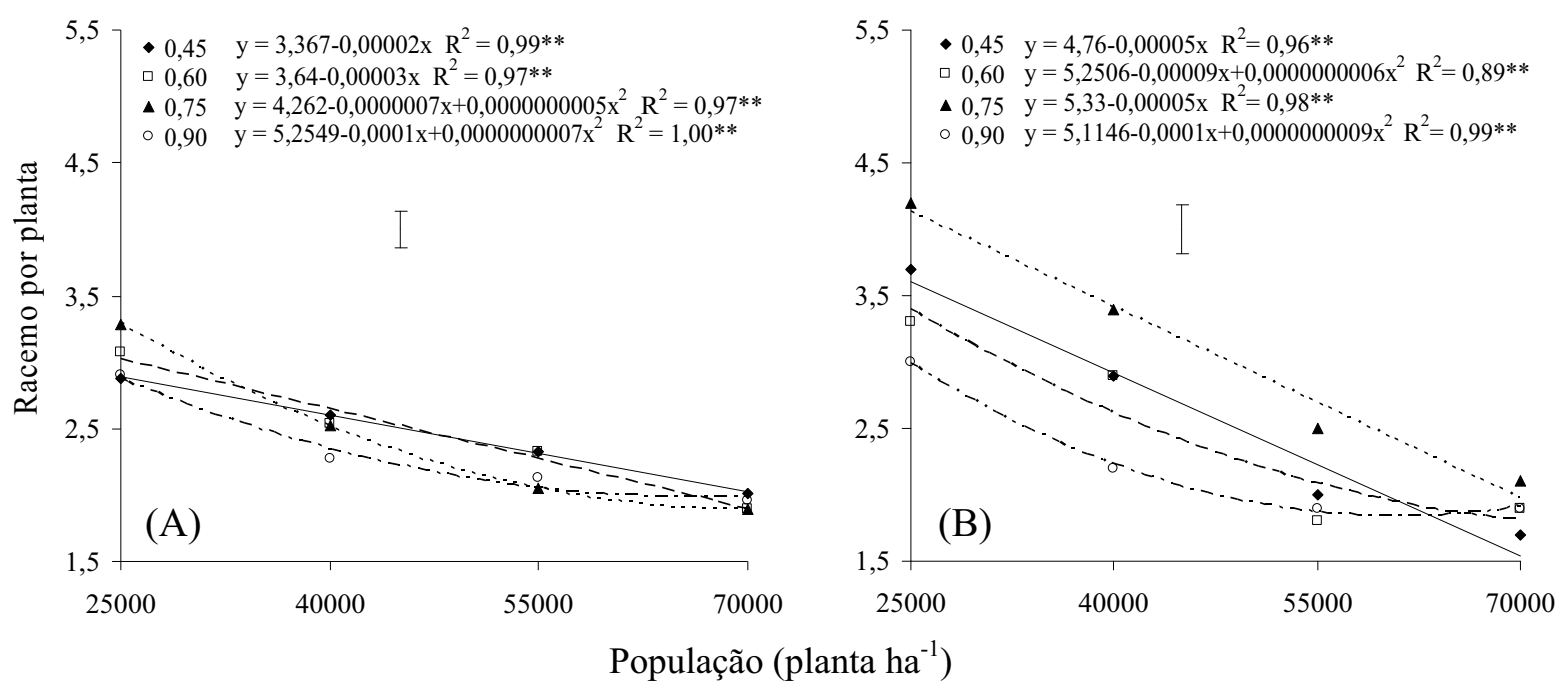

Figura 23. Número de racemo por planta da cultivar de mamona FCA-PB em função da população de plantas e do espaçamento entre fileiras nas safrinhas 2008 (A) e 2009 (B). ** é significativo a 1\% de probabilidade pelo teste $\mathrm{F}$. 


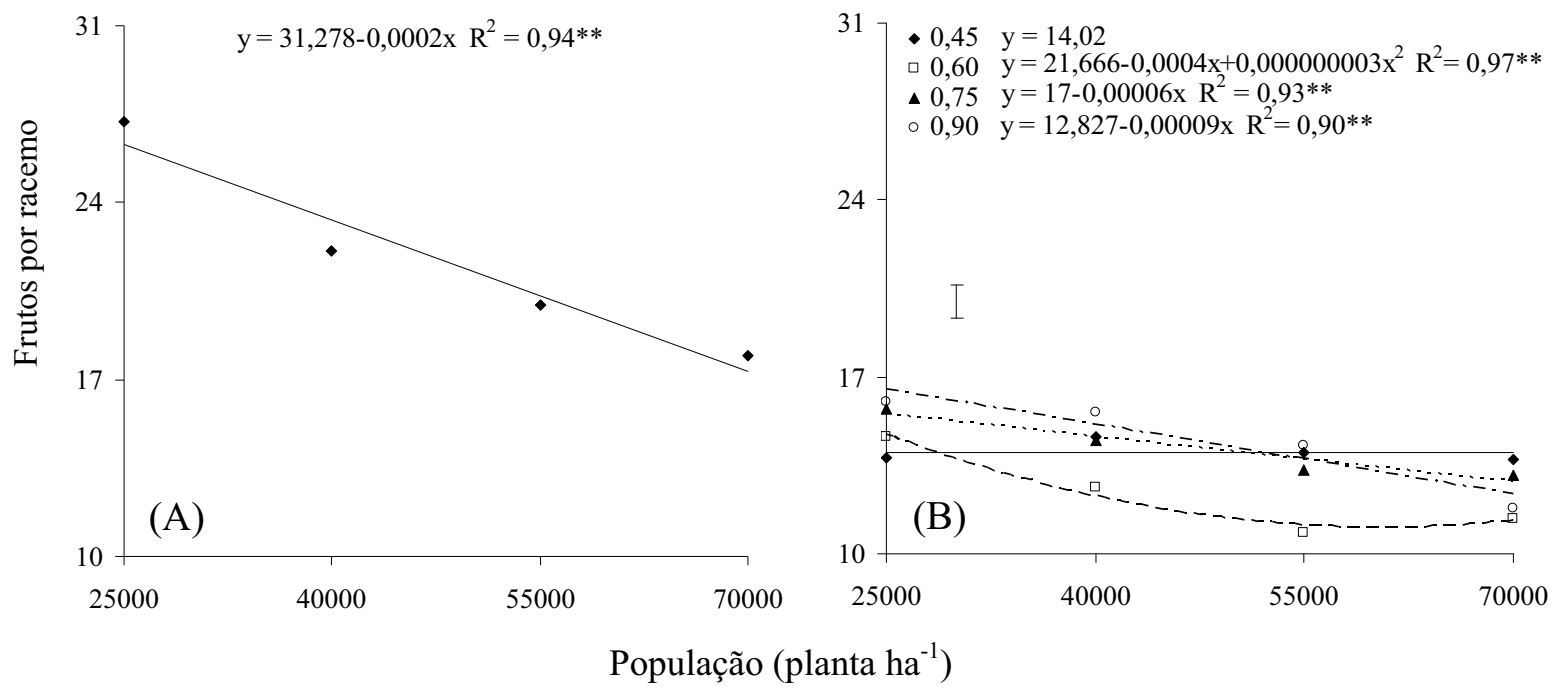

Figura 24. Número de frutos por racemo da cultivar de mamona FCA-PB em função da população de plantas, na média de quatro espaçamentos entre fileiras na safrinha 2008 (A) e cada um dos quatro espaçamentos entre fileiras na safrinha 2009 (B). ** é significativo a $1 \%$ de probabilidade pelo teste $\mathrm{F}$.

O espaçamento entre fileiras e a interação entre espaçamento e população de plantas influenciou o número de grãos por fruto da cultivar de mamona FCAPB, somente na safrinha 2008 (Tabela 18 e Figura 25). As plantas que se encontravam no espaçamento entre fileiras mais estreito $(0,45 \mathrm{~m})$ apresentaram frutos com menor número de grãos, em relação aos demais espaçamentos. Quanto à interação entre os fatores, constatou-se que, em todos os espaçamentos entre fileiras, o incremento da população de plantas promoveu um decréscimo nos valores médios dessa variável, sendo os dados ajustados a funções lineares, para os espaçamentos 0,45 e 0,60 m, e quadráticas para os de 0,75 e 0,90 m (Figura 20). A redução no número de racemos por planta (Figura 23), de frutos por racemo (Figura 24) e de grãos por fruto (Figura 25) pode estar relacionada à manutenção da espécie, isto é, se a produção de fotoassimilados é reduzida, em função do auto-sombreamento proporcionado pelas maiores populações de plantas, por exemplo, é normal que haja redução nos componentes de produção, alterando se características do individuo isoladamente, mas mantendo-se as características que possibilitem a perpetuação da espécie (SILVA, 2008). Além disso, o fato de terem ocorrido menores precipitações nos meses de maio, junho e julho 
de 2008, em comparação ao mesmo período de 2009, pode ter prejudicado a formação e enchimento dos grãos no primeiro ano (Figura 1 e 2), já que nesse ano o número frutos por racemos foi maior, o que também pode ter agravado a competição por fotoassimilados.

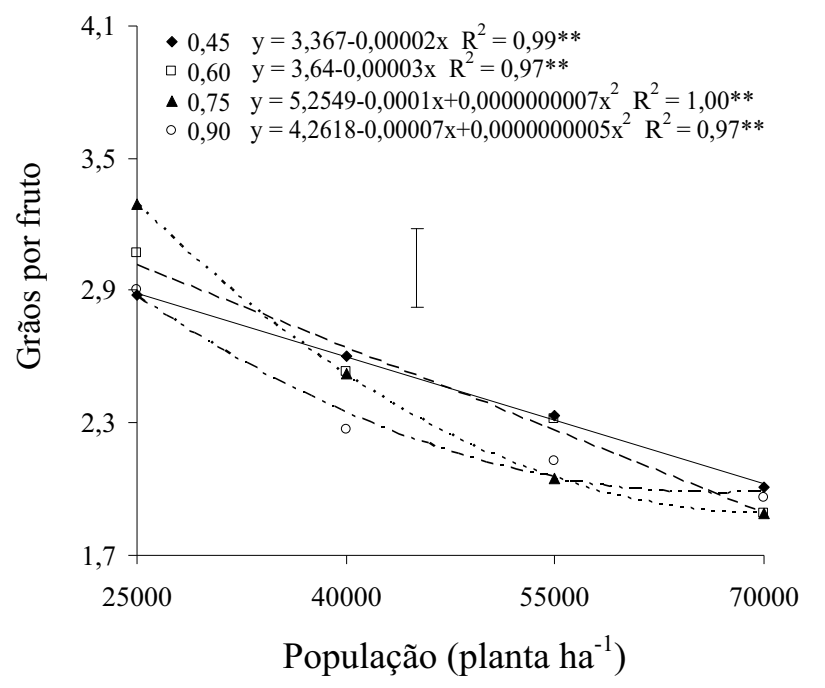

Figura 25. Número de grãos por fruto da cultivar de mamona FCA-PB em função da população de plantas e do espaçamento entre fileiras na safrinha 2008. ** é significativo a $1 \%$ de probabilidade pelo teste $\mathrm{F}$.

A massa de 100 grãos foi alterada pela população de plantas, na safrinha 2008, e pelo espaçamento entre fileiras, na safrinha 2009 (Tabela 19 e Figura 26). Em 2008, os dados se ajustaram à equação polinomial de regressão em função da população de plantas (Figura 26). O ajuste quadrático ocorreu provavelmente devido aos componentes de produção (drenos), racemos por planta (Figura 23A), frutos por racemo (Figura $25 \mathrm{~A}$ ) e grãos por fruto apresentarem os menores valores, quando submetidos as maiores populações de plantas. Em 2009, os maiores valores de massa de 100 grãos foram proporcionados pelos espaçamentos de 0,45 e $0,90 \mathrm{~m}$ entre fileiras, enquanto que, os menores valores ocorreram nos espaçamentos intermediários $(0,60$ e $0,75 \mathrm{~m})$. 
No primeiro ano, o espaçamento entre fileiras e a interação espaçamento $\mathrm{x}$ população de plantas influenciaram significativamente a produtividade de grãos, já no segundo, houve efeitos dos fatores e da interação (Tabela 19).

Tabela 19. Massa de 100 grãos e produtividade de grãos da cultivar de mamona FCA-PB, nas safrinhas 2008 e 2009, em função do espaçamento e população de plantas. Botucatu, SP.

\begin{tabular}{|c|c|c|c|c|}
\hline \multirow{2}{*}{ Fontes de variação } & \multicolumn{2}{|c|}{ Massa de 100 grãos } & \multicolumn{2}{|c|}{ Produtividade de grãos } \\
\hline & 2008 & 2009 & 2008 & 2009 \\
\hline Espaçamento (m) & \multicolumn{2}{|c|}{$(\mathrm{g})$} & \multicolumn{2}{|c|}{$\left(\mathrm{kg} \mathrm{ha}^{-1}\right)^{-}$} \\
\hline 0,45 & $38,4 a^{(1)}$ & $47,5 \mathrm{a}$ & $1.852 \mathrm{a}$ & $2.072 b$ \\
\hline 0,60 & $37,7 \mathrm{a}$ & $45,0 \mathrm{~b}$ & $1.923 \mathrm{a}$ & $1.572 \mathrm{~d}$ \\
\hline 0,75 & $37,3 \mathrm{a}$ & $45,4 b$ & $1.882 \mathrm{a}$ & $2.391 \mathrm{a}$ \\
\hline 0,90 & $37,0 \mathrm{a}$ & $47,4 \mathrm{a}$ & $1.666 \mathrm{~b}$ & $1.826 \mathrm{c}$ \\
\hline C.V. $(\%)$ & 7,0 & 3,5 & 8,4 & 8,2 \\
\hline \multicolumn{5}{|l|}{ População (plantas ha ${ }^{-1}$ ) } \\
\hline 25.000 & 38,3 & 47,4 & 1.710 & 1.780 \\
\hline 40.000 & 36,5 & 46,1 & 1.865 & 2.116 \\
\hline 55.000 & 37,3 & 45,8 & 1.875 & 1.896 \\
\hline 70.000 & 38,3 & 46,0 & 1.872 & 2.068 \\
\hline C.V. $(\%)$ & 6,8 & 6,7 & 14,2 & 8,8 \\
\hline \multicolumn{5}{|l|}{ Teste F } \\
\hline Espaçamento (E) & $0,85 \mathrm{~ns}$ & $9,84 * *$ & $8,72 * *$ & $76,08 * *$ \\
\hline \multicolumn{5}{|l|}{ População inicial (P) } \\
\hline Reg. Linear & $0,14 \mathrm{~ns}$ & $0,94 \mathrm{~ns}$ & $2,91 \mathrm{~ns}$ & $11,11 * *$ \\
\hline Reg. Quadrática & $4,80^{*}$ & $1,70 \mathrm{~ns}$ & $1,48 \mathrm{~ns}$ & $3,61 \mathrm{~ns}$ \\
\hline$E \times P$ & $1,66 \mathrm{~ns}$ & $0,87 \mathrm{~ns}$ & $4,71 * *$ & $2,98 * *$ \\
\hline
\end{tabular}




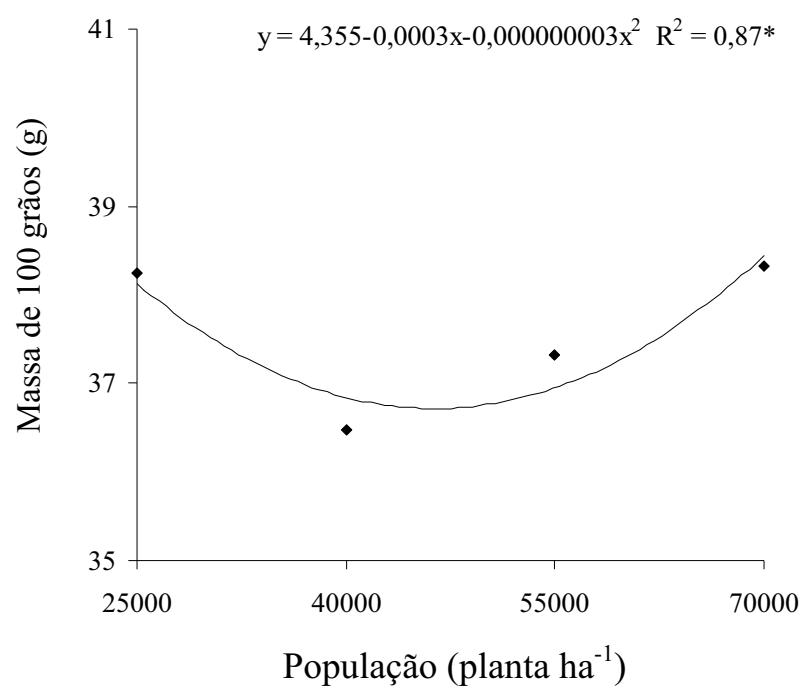

Figura 26. Massa de 100 grãos da cultivar de mamona FCA-PB em função da população de plantas na safrinha 2008. * é significativo a 5\% de probabilidade pelo teste $\mathrm{F}$.

De maneira geral, as maiores produtividades de grãos, na safrinha 2008, foram proporcionadas pelos menores espaçamentos entre fileiras $(0,45,0,60$ e $0,75 \mathrm{~m})$, com produtividade média de $1.886 \mathrm{~kg} \mathrm{ha}^{-1}$, diferindo apenas do maior espaçamento $(0,90 \mathrm{~m})$, que proporcionou produtividade de grãos de $1.666 \mathrm{~kg} \mathrm{ha}^{-1}$, ou seja, os menores espaçamentos proporcionaram produtividade de grãos em média 13\% superior ao espaçamento mais largo. $\mathrm{Na}$ safrinha 2009, a maior produtividade de grãos foi proporcionada pelo espaçamento de 0,75 $\mathrm{m}$ entre fileiras, com produtividade de grãos de $2.391 \mathrm{~kg} \mathrm{ha}^{-1}$, enquanto que a menor produtividade $\left(1.572 \mathrm{~kg} \mathrm{ha}^{-1}\right)$ foi proporcionada pelo espaçamento de 0,60 $\mathrm{m}$. Analisando a interação entre espaçamento e população de plantas (Figura 27), verifica-se que, principalmente na menor população, em 2008, e de maneira geral em 2009, o espaçamento entre fileiras de $0,75 \mathrm{~m}$ proporcionou as maiores produtividades de grãos. Severino et al. (2006b) constataram que no espaçamento de $3 \mathrm{~m}$ entre fileiras, tradicionalmente recomendado para a cultivar BRS Nordestina, a produtividade obtida foi de $1.398 \mathrm{~kg} \mathrm{ha}^{-1}$, enquanto a redução do espaçamento para $2 \mathrm{~m}$ possibilitou aumento de $48 \%$ na produtividade de grãos, obtendo- se $2.038 \mathrm{~kg} \mathrm{ha}^{-1}$. Vale (2009) também obteve incremento da produtividade de grãos com redução no espaçamento entre fileiras. Contudo, é importante ressaltar que nos dois trabalhos supracitados, a redução do espaçamento não foi acompanhada de alteração na distância entre as plantas dentro da fileira, ou seja, a redução do espaçamento entre fileiras 
ocasionou aumento da população de plantas. No presente trabalho, a alteração no espaçamento não incorreu em alteração da população de plantas por área, já que a distância entre as mesmas na fileira foi alterada (Tabela 2). Assim, é possível inferir que mesmo não aumentando o número de plantas por área, o espaçamento de $0,75 \mathrm{~m}$ proporcionou aumento de produtividade de grãos, por melhorar o arranjo espacial das plantas, reduzindo assim a competição intraespecífica dentro da fileira.

Em 2008, os dados de produtividades de grãos foram ajustados a funções quadráticas para os espaçamentos de 0,60 e 0,75 m e lineares para os espaçamentos de 0,45 e 0,90 m entre fileiras (Figura 27A). No espaçamento de 0,60 m entre fileiras, a máxima produtividade de grãos foi obtida na população estimada de 49.833 plantas ha ${ }^{-1}$. Já para o espaçamento de $0,75 \mathrm{~m}$ entre fileiras, a produtividade de grãos diminuiu com o aumento da população de plantas até a população calculada de 51.055 plantas por ha ${ }^{-1}$, aumentando em seguida com o incremento da população para 70.000 plantas. Observa-se assim um efeito de compensação, devido ao maior número de plantas na área. No ano de 2009, o aumento da população de plantas promoveu um incremento linear na produtividade de grãos no espaçamento de $0,90 \mathrm{~m}$, enquanto que, no espaçamento de $0,45 \mathrm{~m}$, os dados foram ajustados a função quadrática (Figura 27B), atingindo o máximo de produtividade de grãos na população calculada de 54.583 plantas ha ${ }^{-1}$. A produtividade das plantas cultivadas nos espaçamentos de $0,60 \mathrm{~m}$ e $0,75 \mathrm{~m}$ entre fileiras, não foram influenciados pelo aumento da população de plantas. Vale (2009) verificou que a máxima produtividades de grãos, para a cultivar BRS Energia, ocorreu nos menores espaçamentos entre fileiras $(0,50 \mathrm{~m} \mathrm{e} 0,75 \mathrm{~m})$ e, consequentemente maiores populações (20.000 e 13.333 plantas $\mathrm{ha}^{-1}$ ). $\mathrm{O}$ autor salienta que são necessários outros estudos de otimização do espaçamento já que as condições edafoclimáticas mudam de acordo com a região, podendo, portanto, maiores espaçamentos obter produtividades superiores as de menor espaçamento. Segundo Azevedo et al. (2001), analisando-se uma série de experimentos sobre população de plantas, constataram que a disponibilidade de água sempre se destaca como o principal fator para definição da população de plantas ideal, ficando em segundo plano a fertilidade do solo e os outros fatores ligados ao clima. 

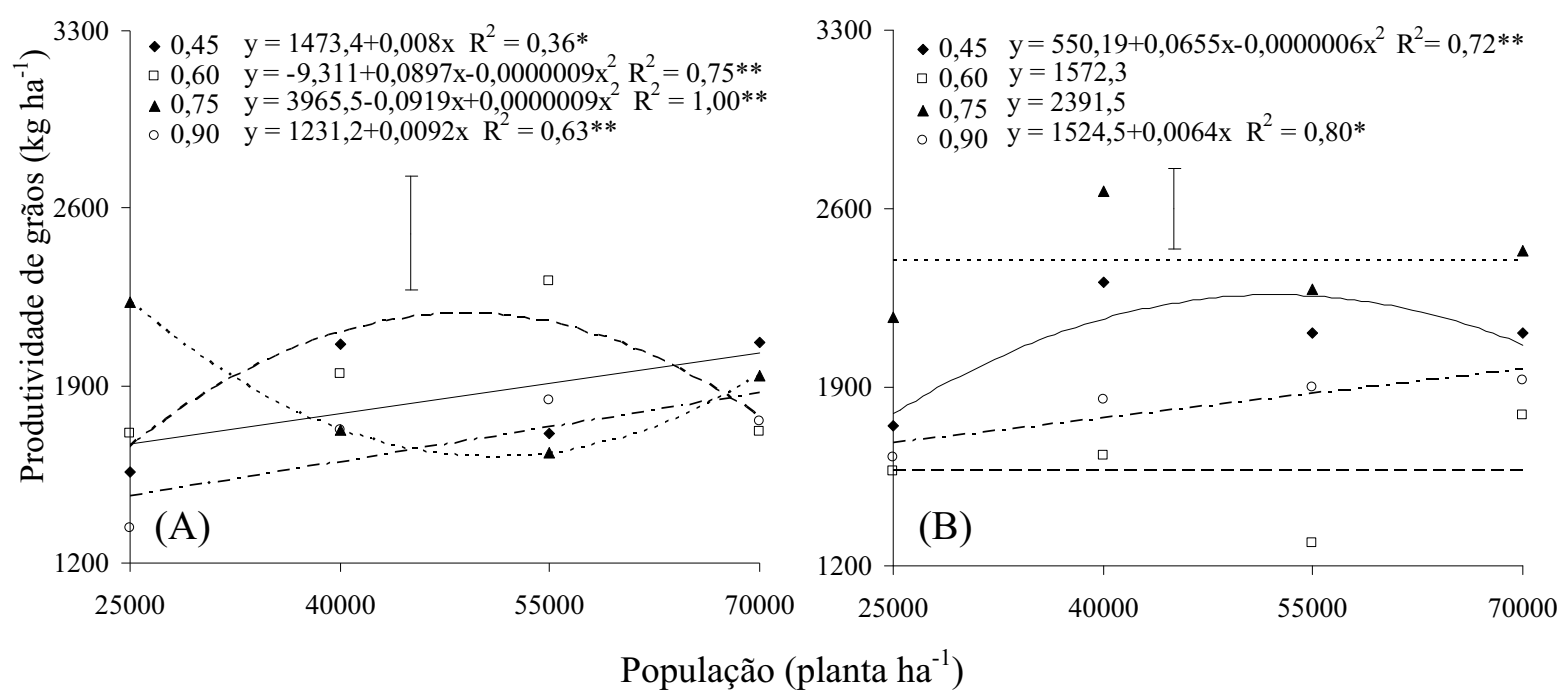

Figura 27. Produtividade de grãos da cultivar de mamona FCA-PB em função da população de plantas e do espaçamento entre fileiras nas safrinhas 2008 (A) e 2009 (B). * e ** são significativos a $5 \%$ e $1 \%$ de probabilidade pelo teste $\mathrm{F}$, respectivamente.

Não houve alteração no teor de óleo do grão da cultivar FCA-PB, na safrinha, em função dos fatores estudados (Tabela 20).

A produtividade de óleo, na safrinha 2008, foi significativamente influenciada pelo espaçamento entre fileiras, população de plantas e a interação (espaçamento x população), e na safrinha 2009, foram constatados efeitos apenas do espaçamento e da interação entre os fatores (Tabela 20).

Assim como para a produtividade de grãos (Tabela 19), de maneira geral, as maiores produtividades de óleo foram obtidas no espaçamento entre fileiras de 0,75 m (Tabela 19). Além disso, analisando os desdobramentos da interação, verifica-se que no primeiro ano as maiores produtividades de óleo foram obtidas no espaçamento de $0,75 \mathrm{~m}$ com a população de 25.000 plantas ha $^{-1}$ e no espaçamento de $0,60 \mathrm{~m}$ com população de 55.000 plantas ha ${ }^{-1}$ (Figura 28A). Já no segundo ano, apesar da interação, as maiores produtividade de óleo foram obtidas no espaçamento de $0,75 \mathrm{~m}$, independentemente da população utilizada (Figura 28B). 
Tabela 20. Teor de óleo no grão e produtividade de óleo da cultivar de mamona FCA-PB, nas safrinhas 2008 e 2009, em função do espaçamento e população de plantas. Botucatu, SP.

\begin{tabular}{|c|c|c|c|c|}
\hline \multirow{2}{*}{ Fontes de variação } & \multicolumn{2}{|c|}{ Teor de óleo no grão } & \multicolumn{2}{|c|}{ Produtividade de óleo } \\
\hline & 2008 & 2009 & 2008 & 2009 \\
\hline Espaçamento (m) & \multicolumn{2}{|c|}{$(\%)$} & \multicolumn{2}{|c|}{$\left(\mathrm{kg} \mathrm{ha}^{-1}\right)^{-}$} \\
\hline 0,45 & $45,5 \mathrm{a}$ & $46,9 \mathrm{a}$ & $733 a$ & $846 b$ \\
\hline 0,60 & $44,6 \mathrm{a}$ & $46,3 \mathrm{a}$ & $743 a$ & $634 d$ \\
\hline 0,75 & $46,2 \mathrm{a}$ & $46,9 \mathrm{a}$ & $758 \mathrm{a}$ & $977 \mathrm{a}$ \\
\hline 0,90 & $45,5 \mathrm{a}$ & $46,3 a$ & $648 b$ & $736 \mathrm{c}$ \\
\hline C.V. $(\%)$ & 5,4 & 4,6 & 10,0 & 10,0 \\
\hline \multicolumn{5}{|l|}{ População (plantas ha ${ }^{-1}$ ) } \\
\hline 25.000 & 45,0 & 46,6 & 674 & 724 \\
\hline 40.000 & 43,9 & 46,9 & 714 & 868 \\
\hline 55.000 & 45,6 & 46,4 & 746 & 766 \\
\hline 70.000 & 46,1 & 46,4 & 750 & 834 \\
\hline C.V. $(\%)$ & 5,0 & 4,2 & 15,8 & 10,4 \\
\hline \multicolumn{5}{|l|}{ Teste F } \\
\hline Espaçamento (E) & $2,05 \mathrm{~ns}$ & $0,52 \mathrm{~ns}$ & $7,52 * *$ & $54,58 * *$ \\
\hline \multicolumn{5}{|l|}{ População inicial (P) } \\
\hline Reg. Linear & $3,79 \mathrm{~ns}$ & $0,30 \mathrm{~ns}$ & $4,16^{*}$ & $5,99 \mathrm{~ns}$ \\
\hline Reg. Quadrática & $2,05 \mathrm{~ns}$ & $0,12 \mathrm{~ns}$ & $0,40 \mathrm{~ns}$ & $3,36 \mathrm{~ns}$ \\
\hline $\mathrm{E} \times \mathrm{P}$ & $1,83 \mathrm{~ns}$ & $1,80 \mathrm{~ns}$ & $4,47 * *$ & $3,13 * *$ \\
\hline
\end{tabular}

Em 2008, o aumento da população de plantas, no espaçamento 0,75 m entre fileiras, proporcionou redução na produtividade de óleo, sendo que nos demais espaçamentos, ocorreram incrementos nos valores dessa variável em função do aumento da população de plantas (Figura 28A). Na safrinha 2009, não verificou-se efeito na produtividade de óleo, em função da população de plantas nos espaçamentos de 0,75 e 0,90 m entre fileiras (Figura 28B), porém, nos espaçamentos de 0,45 e 0,60 m, o aumento da população de plantas 
influenciou significativamente a produtividade óleo, com ajustes dos dados a modelos quadráticos de regressão.
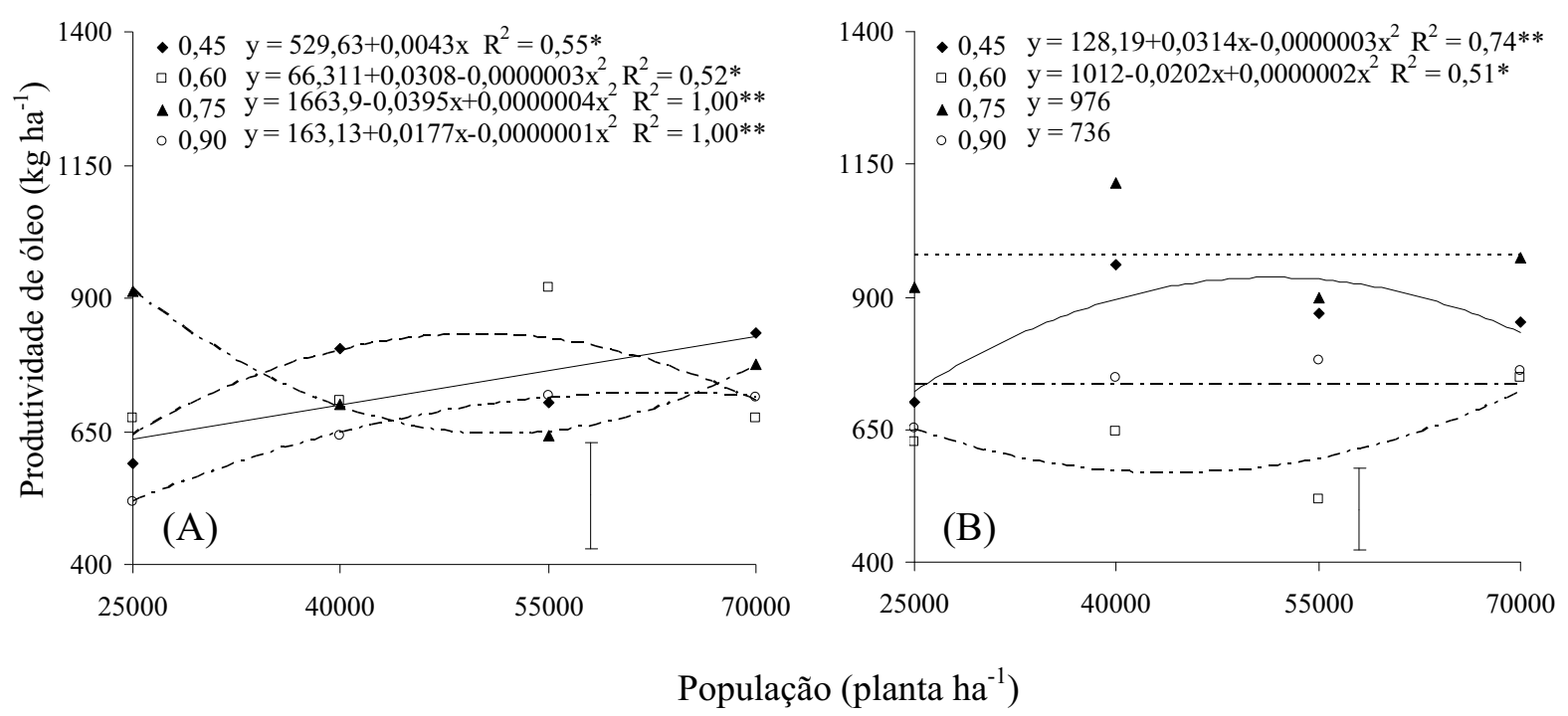

Figura 28. Produtividade de óleo da cultivar de mamona FCA-PB em função da população de plantas e do espaçamento entre fileiras nas safrinhas 2008 (A) e 2009 (B). * e ** são significativos a $5 \%$ e $1 \%$ de probabilidade pelo teste $\mathrm{F}$, respectivamente.

\subsubsection{Cultivar IAC 2028}

Para a cultivar IAC 2028, praticamente não se observou diferenças entre as populações de plantas previamente estabelecidas e obtidas na colheita (Tabela 21), diferentemente do observado para esta cultivar nas safras de verão ou para a cultivar FCA-PB em ambas as épocas de cultivo (Tabelas 3, 9 e 15). 
Tabela 21. População final de plantas obtida na colheita da mamona cultivar IAC $2028 \mathrm{em}$ função do espaçamento entre fileiras e da população inicial de plantas, nas safrinhas 2008 e 2009. Botucatu - SP.

\begin{tabular}{|c|c|c|c|c|c|}
\hline \multirow{2}{*}{ População inicial } & \multicolumn{4}{|c|}{ Espaçamento (m) } & \multirow{2}{*}{ Média } \\
\hline & 0,45 & 0,60 & 0,75 & 0,90 & \\
\hline \multicolumn{6}{|c|}{ - $\left(\right.$ plantas $\left.\mathrm{ha}^{-1}\right)$} \\
\hline \multicolumn{6}{|c|}{ Safrinha 2008} \\
\hline 25.000 & 25.000 & 25.000 & 25.000 & 25.000 & $25.000(100 \%)^{(1)}$ \\
\hline 40.000 & 40.000 & 40.000 & 40.000 & 40.000 & $40.000(100 \%)$ \\
\hline 55.000 & 52.500 & 55.000 & 55.000 & 55.000 & $54.375(98,9 \%)$ \\
\hline 70.000 & 70.000 & 70.000 & 69.998 & 70.000 & $70.000(100 \%)$ \\
\hline \multicolumn{6}{|c|}{ Safrinha 2009} \\
\hline 25.000 & 25.000 & 25.000 & 24.972 & 25.000 & 24.993(99,9\%) \\
\hline 40.000 & 40.000 & 39.972 & 39.611 & 39.870 & $39.863(99,6 \%)$ \\
\hline 55.000 & 55.000 & 55.000 & 54.917 & 54.806 & $54.930(99,8 \%)$ \\
\hline 70.000 & 66.667 & 69.444 & 69.444 & 66.667 & $68.055(97,2 \%)$ \\
\hline
\end{tabular}

O espaçamento entre fileiras e a população de plantas influenciaram significativamente a massa de matéria seca da parte aérea, nos dois anos (Tabela 22 e Figura 29). Na safrinha 2008, os maiores valores de matéria seca foram observados nos menores espaçamentos entre fileiras $(0,45$ e $0,650 \mathrm{~m})$, enquanto que, os menores espaçamentos $(0,75 \mathrm{e}$ 0,90 m) entre fileiras proporcionaram as menores médias dessa variável. Na safrinha 2009, a maior produção de matéria seca $(56,6 \mathrm{~g})$ foi proporcionada pelo espaçamento de $0,90 \mathrm{~m}$ entre fileiras, diferindo apenas do espaçamento de 0,75 m, que apresentou valores médios de 47,8 g.

O aumento da população de plantas proporcionou decréscimo significativo na produção de matéria seca da cultivar IAC 2028, em ambos os anos (Figura 29). O mesmo efeito também foi constatado para a cultivar FCA-PB (Figura 19). A maior produção de matéria seca na população de 25.000 plantas ha ${ }^{-1}$ ocorreu em função do maior crescimento das plantas, que, provavelmente, foi favorecido pela menor competição entre elas, resultando em maior crescimento individual. O aumento da população de planta na área reduz a distância entre as plantas na fileira (Tabela 2) e, consequentemente, aumenta a 
competição por fatores ambientais (água, luz e nutrientes) necessários para o seu crescimento e desenvolvimento (ANDRADE et al., 1971), resultando em menor produção de biomassa.

Tabela 22. Matéria seca da parte aérea e diâmetro do caule da cultivar de mamona IAC 2028, nas safrinhas 2008 e 2009 , em função do espaçamento e população de plantas. Botucatu, SP.

\begin{tabular}{|c|c|c|c|c|}
\hline \multirow{2}{*}{ Fontes de variação } & \multicolumn{2}{|c|}{ Matéria seca da parte aérea } & \multicolumn{2}{|c|}{ Diâmetro do caule } \\
\hline & 2008 & 2009 & 2008 & 2009 \\
\hline Espaçamento (m) & \multicolumn{2}{|c|}{$\left(\right.$ g planta $\left.^{-1}\right)$} & \multicolumn{2}{|c|}{$(\mathrm{mm})$} \\
\hline 0,45 & $71,7 \mathrm{a}^{(1)}$ & $50,3 \mathrm{ab}$ & $24,1 \mathrm{ab}$ & $23,1 \mathrm{a}$ \\
\hline 0,60 & $73,3 \mathrm{a}$ & $49,2 \mathrm{ab}$ & $25,3 \mathrm{a}$ & $23,1 \mathrm{a}$ \\
\hline 0,75 & $59,9 \mathrm{~b}$ & $47,8 b$ & $22,6 b$ & $23,2 \mathrm{a}$ \\
\hline 0,90 & $59,6 b$ & $56,6 \mathrm{a}$ & $23,3 a b$ & $23,4 \mathrm{a}$ \\
\hline C.V. $(\%)$ & 12,5 & 14,2 & 8,6 & 3,5 \\
\hline \multicolumn{5}{|l|}{ População (plantas ha" ${ }^{-1}$ ) } \\
\hline 25.000 & 90,3 & 66,7 & 27,3 & 28,0 \\
\hline 40.000 & 67,1 & 52,5 & 23,7 & 24,0 \\
\hline 55.000 & 55,8 & 43,9 & 22,8 & 21,1 \\
\hline 70.000 & 51,3 & 41,0 & 21,4 & 19,7 \\
\hline C.V. $(\%)$ & 13,1 & 13,7 & 6,1 & 3,2 \\
\hline \multicolumn{5}{|l|}{ Teste F } \\
\hline Espaçamento (E) & $12,96 * *$ & $4,66^{*}$ & $5,13 *$ & $0,49 \mathrm{~ns}$ \\
\hline \multicolumn{5}{|l|}{ População inicial (P) } \\
\hline Reg. Linear & $176,49 * *$ & $120,69 * *$ & $128,60 * *$ & $1143,15^{* *}$ \\
\hline Reg. Quadrática & $18,55^{* *}$ & $10,46^{* *}$ & $9,43 * *$ & $51,28 * *$ \\
\hline $\mathrm{E} \times \mathrm{P}$ & $1,80 \mathrm{~ns}$ & $1,39 \mathrm{~ns}$ & $1,79 \mathrm{~ns}$ & $1,96 \mathrm{~ns}$ \\
\hline
\end{tabular}




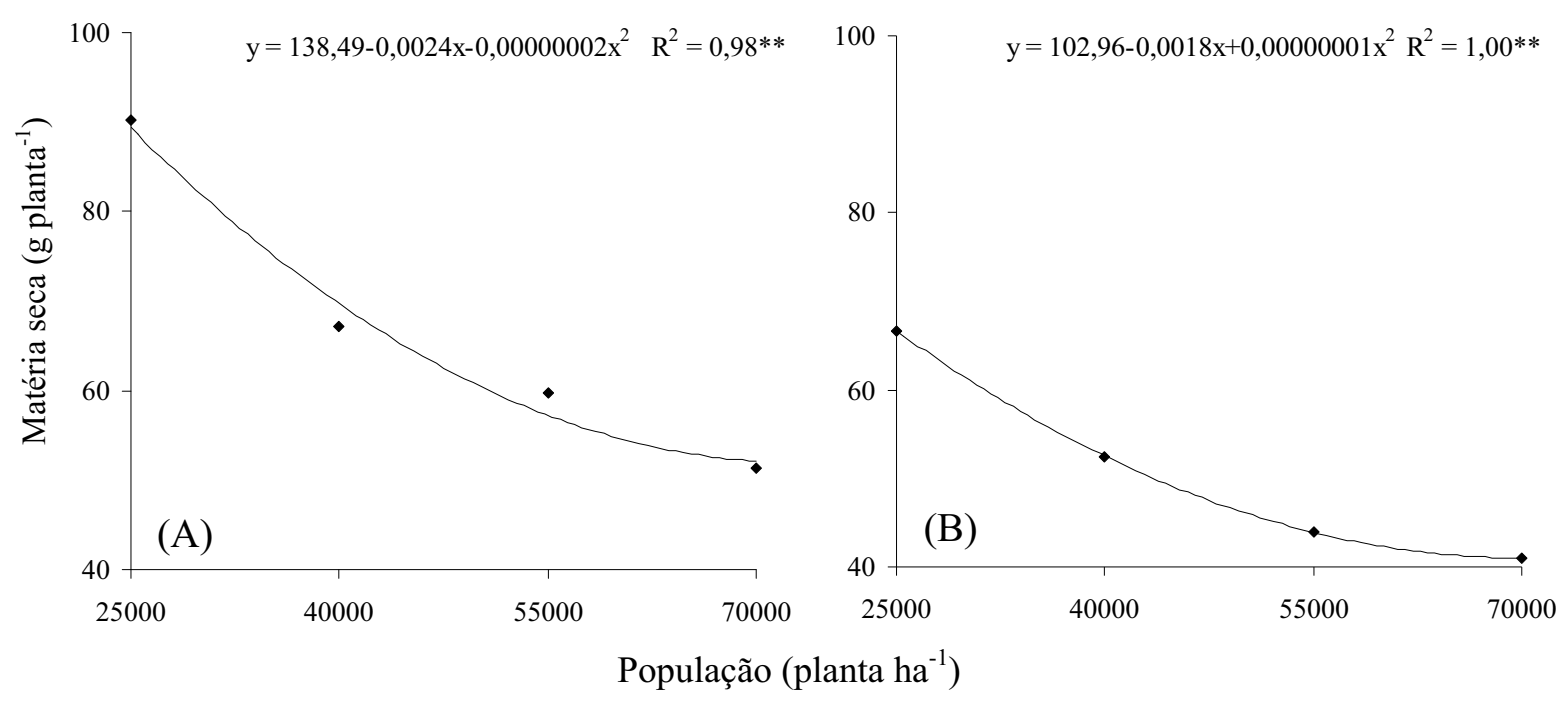

Figura 29. Matéria seca da parte aérea da cultivar de mamona IAC 2028 em função da população de plantas nas safrinhas 2008 (A) e 2009 (B). ** é significativo a 1\% de probabilidade pelo teste $\mathrm{F}$.

O diâmetro do caule sofreu influência do espaçamento entre fileiras, em 2008, e da população de plantas, nos dois anos de cultivo (Tabela 22). No primeiro ano, plantas que se encontravam no espaçamento de $0,60 \mathrm{~m}$ apresentaram o maior diâmetro $(25,3$ $\mathrm{mm}$ ), porém, diferindo apenas daquelas submetidas ao espaçamento de 0,75 $\mathrm{m}$, que apresentaram diâmetro de 22,6 mm. Resultados condizentes com os observados para matéria seca. $\mathrm{O}$ espaçamento entre fileiras de $0,60 \mathrm{~m}$ proporcionou distribuição mais equidistante das plantas na área (Tabela 2), especialmente nas menores populações, o que pode ter reduzido a competição entre estas, com consequente incremento na produção de matéria seca e diâmetro do caule. Contudo, o diâmetro do caule não foi alterado pelo espaçamento no segundo ano do experimento.

O diâmetro do caule foi reduzido com o aumento da população de plantas, nos dois anos de cultivo (Figura 30), sendo esse efeito, semelhante ao observado na matéria seca da parte aérea (Figura 29), o que pode ser explicado pela maior competição entre as plantas na fileira por luz especialmente por luz. Efeito semelhante foi observado nos demais experimentos. Isso ocorre, porque a alteração no arranjo de plantas, especialmente adensamento na fileira, afeta a qualidade de luz interceptada e ocasiona maior absorção de luz na faixa do vermelho (V) e maior reflexão na do vermelho extremo (VE). Plantas que recebem 
mais luz VE refletida, ou seja, maior relação $\mathrm{VE} / \mathrm{V}$, apresentam elongação e afinamento do caule (KASPERBAUER; KARLEN, 1994). Severino et al. (2006a), também observaram redução no diâmetro caulinar com o aumento da população de plantas na área (redução do espaçamento entre fileiras, sem alterar a distância entre plantas na fileira).
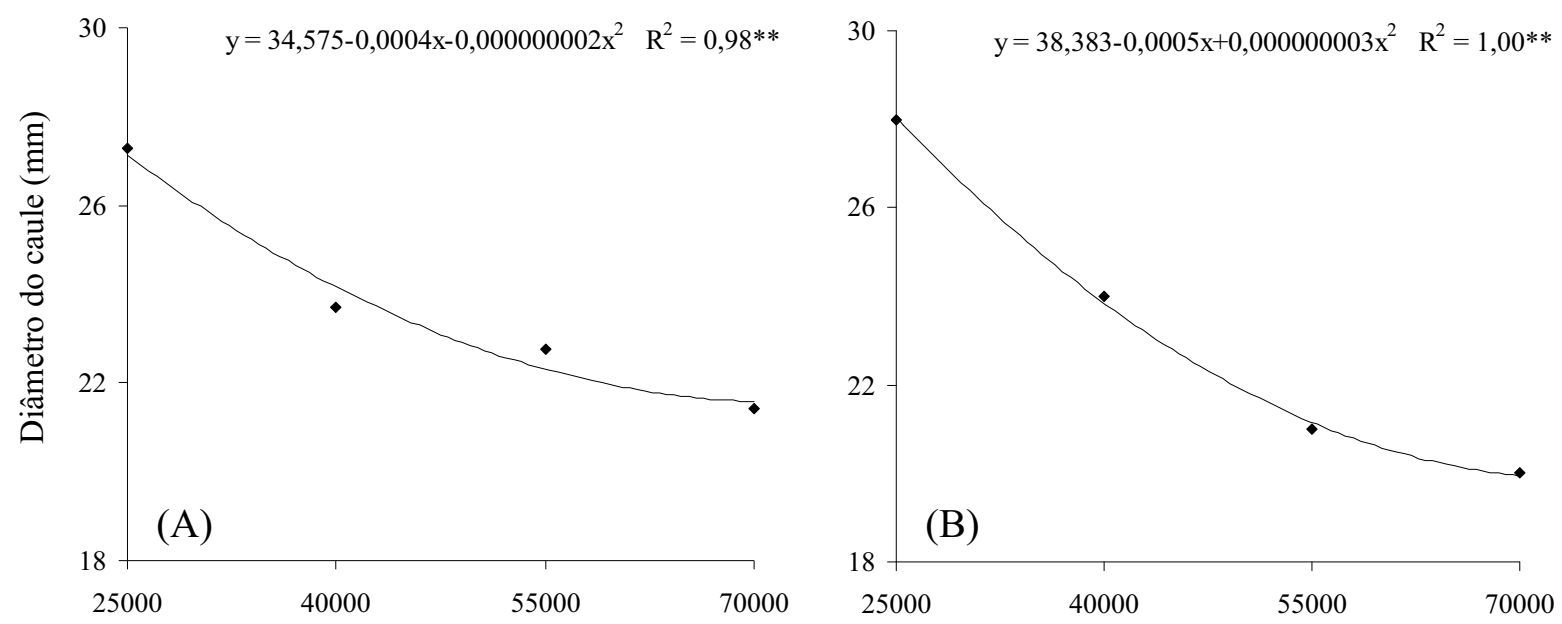

População (planta ha ${ }^{-1}$ )

Figura 30. Diâmetro do caule da cultivar de mamona IAC 2028 em função da população de plantas, na média de quatro espaçamentos entre fileiras na safrinha 2008 (A) e cada um dos quatro espaçamentos entre fileiras na safrinha 2009 (B). ** é significativo a $1 \%$ de probabilidade pelo teste $\mathrm{F}$.

A altura média das plantas foi influenciada pelo espaçamento entre fileiras e população de plantas, na safrinha 2008 (Tabela 23). Na safrinha 2009, além da influência isolada dos fatores, houve também efeito da interação (espaçamento x população de plantas).

No ano de 2008 constatou-se que as plantas submetidas aos espaçamentos mais reduzidos $(0,45$ e $0,60 \mathrm{~m})$ apresentaram maiores alturas. Ferreira et al. (2006), relatam que o uso de espaçamento entre fileiras mais reduzidos podem provocar crescimento excessivo das plantas em altura podendo superar os $2,0 \mathrm{~m}$, mesmo com materiais de porte baixo. Os autores explicam que o crescimento pode ser mais pronunciado em solos férteis ou bem fertilizados, especialmente se houver precipitações elevadas durantes o ciclo da cultura. Na safrinha 2009, o maior espaçamento entre fileiras proporcionou a maior altura de plantas $(1,36 \mathrm{~m})$, diferindo apenas dos espaçamentos de 0,45 e $0,75 \mathrm{~m}$, que apresentaram valor 
médio de altura de planta de $1,27 \mathrm{~m}$. Na safrinha 2009, a média de precipitação foi superior à registrada na safrinha 2008, além de ter sido melhor distribuída em todo o ciclo de desenvolvimento da cultura (Figura 2). Vale (2009) constatou que o estreitamento do espaçamento entre fileiras, com o incremento da população de plantas, proporcionou um aumento na altura de planta, onde no menor espaçamento $0,5 \times 1,0 \mathrm{~m}$ as plantas atingiram altura superiores a 2,0 m. Confirmando os resultados relatados por Ferreira et al. (2006).

Tabela 23. Altura da planta e de inserção do primeiro racemo da cultivar de mamona IAC 2028, nas safrinhas 2008 e 2009, em função do espaçamento e população de plantas. Botucatu, SP.

\begin{tabular}{|c|c|c|c|c|}
\hline \multirow[t]{2}{*}{ Fontes de variação } & \multicolumn{2}{|c|}{$\begin{array}{c}\text { Altura de } \\
\text { planta }\end{array}$} & \multicolumn{2}{|c|}{$\begin{array}{c}\text { Altura de inserção } \\
\text { do } 1^{\underline{o}} \text { racemo }\end{array}$} \\
\hline & 2008 & 2009 & 2008 & 2009 \\
\hline Espaçamento (m) & \multicolumn{4}{|c|}{$(\mathrm{m})$} \\
\hline 0,45 & $1,43 \mathrm{a}^{(1)}$ & $1,27 b$ & $0,71 \mathrm{a}$ & $0,52 \mathrm{a}$ \\
\hline 0,60 & $1,46 \mathrm{a}$ & $1,30 \mathrm{ab}$ & $0,69 \mathrm{a}$ & $0,54 a$ \\
\hline 0,75 & $1,30 \mathrm{~b}$ & $1,28 b$ & $0,60 \mathrm{~b}$ & $0,58 \mathrm{a}$ \\
\hline 0,90 & $1,30 \mathrm{~b}$ & $1,36 \mathrm{a}$ & $0,60 \mathrm{~b}$ & $0,62 \mathrm{a}$ \\
\hline C.V.(\%) & 6,9 & 4,5 & 8,2 & 17,6 \\
\hline \multicolumn{5}{|l|}{ População (plantas ha ${ }^{-1}$ ) } \\
\hline 25.000 & 1,41 & 1,37 & 0,61 & 0,49 \\
\hline 40.000 & 1,32 & 1,34 & 0,61 & 0,56 \\
\hline 55.000 & 1,36 & 1,26 & 0,67 & 0,59 \\
\hline 70.000 & 1,40 & 1,23 & 0,71 & 0,62 \\
\hline C.V. $(\%)$ & 5,2 & 3,5 & 8,5 & 10,8 \\
\hline \multicolumn{5}{|l|}{ Teste $\mathrm{F}$} \\
\hline Espaçamento (E) & $12,04 * *$ & $7,01 * *$ & $18,31 * *$ & $2,94 \mathrm{~ns}$ \\
\hline \multicolumn{5}{|l|}{ População inicial (P) } \\
\hline Reg. Linear & $0,05 \mathrm{~ns}$ & $91,78^{* *}$ & $31,26 * *$ & $40,06^{* *}$ \\
\hline Reg. Quadrática & $12,19 * *$ & $0,66 \mathrm{~ns}$ & $1,46 \mathrm{~ns}$ & $1,65 \mathrm{~ns}$ \\
\hline$E \times P$ & $2,03 \mathrm{~ns}$ & $2,78^{*}$ & $1,10 \mathrm{~ns}$ & $0,86 \mathrm{~ns}$ \\
\hline
\end{tabular}


O efeito da população de plantas (safrinha 2008) e, da interação espaçamento x população (safrinha 2009) na altura de planta estão apresentados na Figura 31. Em 2008 os valores foram ajustados à função polinomial de regressão, apresentado a menor altura de planta na estimada de 50.000 plantas ha $^{-1}$ (Figura 31A). Na interação entre os fatores constata-se que o aumento da população de plantas reduziu significativamente a altura média das plantas, com exceção do espaçamento de $0,90 \mathrm{~m}$ entre fileira, que não foi alterado (Figura 31B). No entanto, na maior população (70.000 plantas $\left.\mathrm{ha}^{-1}\right)$, o espaçamento de $0,90 \mathrm{~m}$ entre fileiras proporcionou altura de planta significativamente maior que os demais espaçamentos. Apesar de alguns materiais genéticos possuírem porte anão, como a cultivar IAC 2028 (SAVY FILHO et al., 2007), a mamona é uma planta perene, que em condições ótimas de desenvolvimento, pode adquirir grandes alturas (BELTRÃO et al., 2007a), o que justifica o observado nesse experimento (Figura 2).

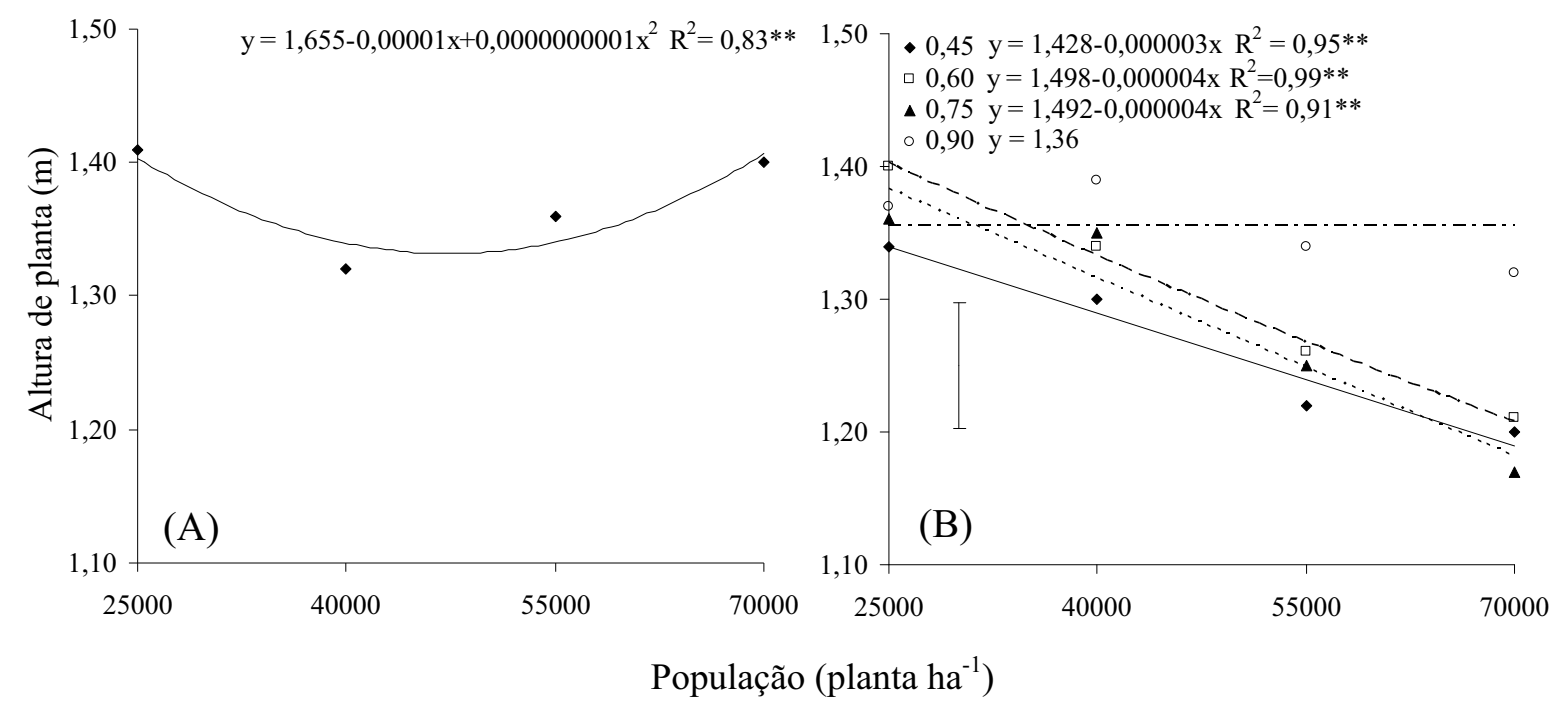

Figura 31 Altura de plantas da cultivar de mamona IAC 2028 em função da população de plantas, na média de quatro espaçamentos entre fileiras na safrinha 2008 (A) e cada um dos quatro espaçamentos entre fileiras na safrinha 2009 (B). ** é significativo a $1 \%$ de probabilidade pelo teste $\mathrm{F}$. 
A altura de inserção do primeiro racemo também foi alterada pelo espaçamento entre fileiras e pela população de plantas, na safrinha 2008, enquanto, na safrinha 2009, verificou-se apenas a influência da população de plantas (Tabela 23). Em 2008, os espaçamentos de 0,45 e 0,60 m entre fileiras contribuíram para a maior altura de inserção do primeiro racemo, com valores médios de 0,71 e 0,69 m, respectivamente. Em 2009, não houve efeito do espaçamento entre fileiras na altura de inserção do primeiro racemo.

$\mathrm{O}$ incremento da população de plantas, em ambos os anos, favoreceu um aumento linear da altura de inserção do racemo primário, sendo os maiores valores

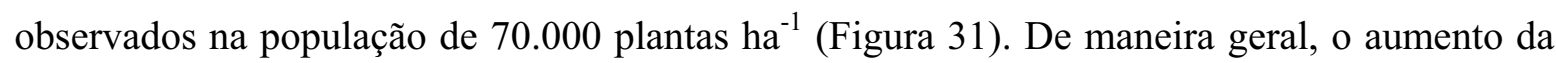
altura da inserção do primeiro racemo proporcionado pelo incremento da população de plantas foi constatado na cultivar FCA-PB e IAC 2028 em todas as safras (2007/08 e 2008/09) e safrinhas (2008 e 2009). Silva et al. (2006) estudando os efeitos de diferentes espaçamentos entre linhas e densidades de plantas, na cultura do algodoeiro, observaram que a maior altura de inserção do primeiro ramo frutífero ocorreu na maior população de plantas. Plantas sob maior competição, especialmente por luz, apresentam maior elongação do caule, em detrimento do seu diâmetro, como foi observado no presente trabalho.

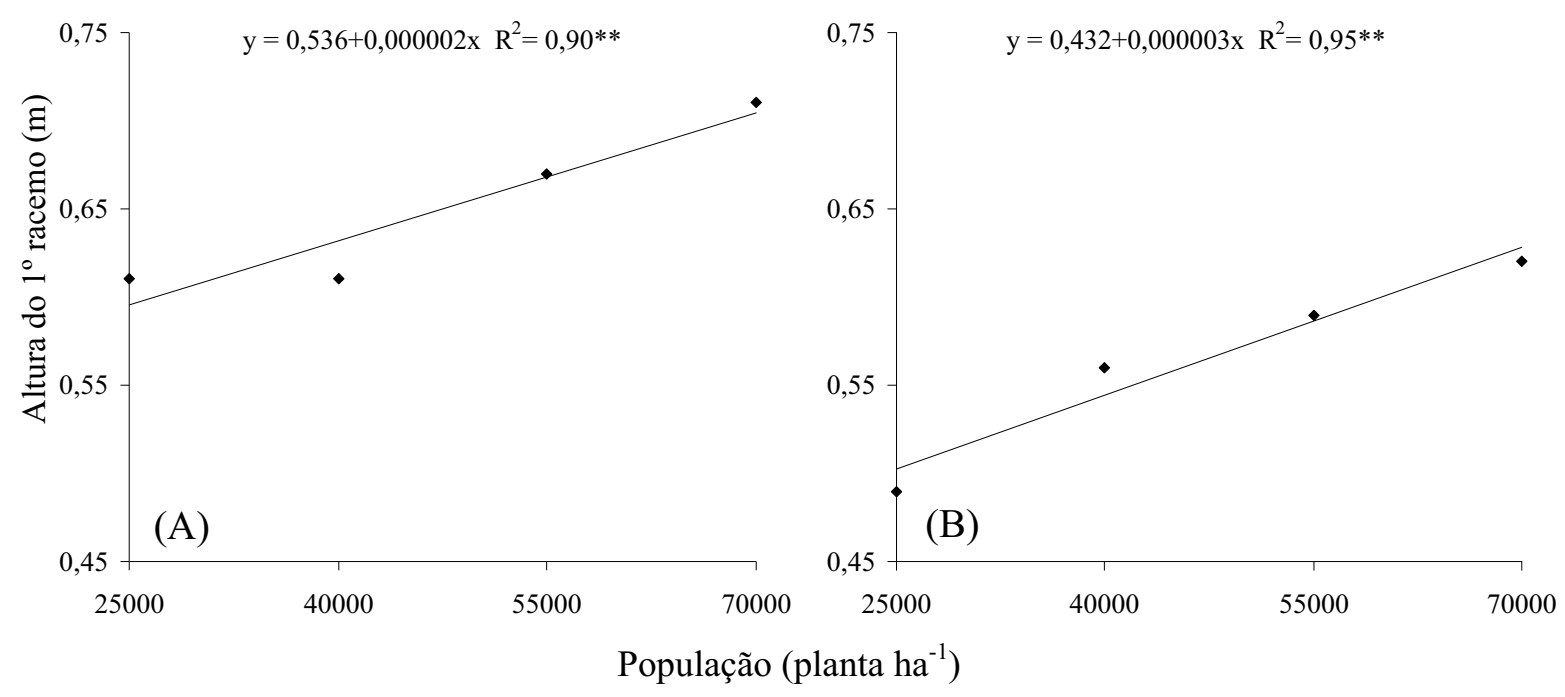

Figura 32. Altura de inserção do primeiro racemo da cultivar de mamona IAC 2028 em função da população de plantas nas safrinhas 2008 (A) e 2009 (B). ** é significativo a $1 \%$ de probabilidade pelo teste $\mathrm{F}$. 
A população de plantas influenciou o número de racemos por planta, no primeiro ano. Já no segundo ano, essa variável foi influenciada pelos fatores e pela interação entre estes. O maior número de racemos por planta, na safrinha 2009, foi constatado no menor espaçamento entre fileiras $(0,45 \mathrm{~m})$, com valor médio de 1,8 racemos por planta, não diferindo dos espaçamentos de 0,60 e $0,75 \mathrm{~m}$, com 1,6 .

Tabela 24. Número de racemos por planta, frutos por racemo e grãos por fruto da cultivar de mamona IAC 2028, nas safrinhas 2008 e 2009, em função do espaçamento e população de plantas. Botucatu, SP.

\begin{tabular}{|c|c|c|c|c|c|c|}
\hline \multirow[t]{2}{*}{ Fontes de variação } & \multicolumn{2}{|c|}{$\begin{array}{c}\mathrm{N}^{\mathrm{o}} \text { de racemos por } \\
\text { planta }\end{array}$} & \multicolumn{2}{|c|}{$\begin{array}{l}\mathrm{N}^{\mathrm{o}} \text { de frutos por } \\
\text { racemo }\end{array}$} & \multicolumn{2}{|c|}{$\begin{array}{l}\text { № de grãos por } \\
\text { fruto }\end{array}$} \\
\hline & 2008 & 2009 & 2008 & 2009 & 2008 & 2009 \\
\hline Espaçamento (m) & \multicolumn{2}{|c|}{$\left(\right.$ racemos planta $\left.^{-1}\right)$} & \multicolumn{2}{|c|}{ (frutos racemo ${ }^{-1}$ ) } & \multicolumn{2}{|c|}{ 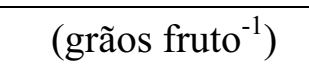 } \\
\hline 0,45 & $1,7 \mathrm{a}^{(1)}$ & $1,8 \mathrm{a}$ & $26,5 \mathrm{a}$ & $16,7 b c$ & $2,52 \mathrm{a}$ & $2,79 a$ \\
\hline 0,60 & $1,7 \mathrm{a}$ & $1,6 \mathrm{ab}$ & $27,8 \mathrm{a}$ & $18,1 \mathrm{a}$ & $2,52 \mathrm{a}$ & $2,79 \mathrm{a}$ \\
\hline 0,75 & $1,6 \mathrm{a}$ & $1,6 a b$ & $23,5 b$ & $16,7 \mathrm{c}$ & $2,49 a$ & $2,82 \mathrm{a}$ \\
\hline 0,90 & $1,6 \mathrm{a}$ & $1,4 b$ & $23,2 b$ & $17,6 a b$ & $2,50 \mathrm{a}$ & $2,77 \mathrm{a}$ \\
\hline C.V.(\%) & 16,5 & 14,9 & 8,9 & 4,7 & 4,0 & 2,5 \\
\hline \multicolumn{7}{|l|}{ População (plantas ha ${ }^{-1}$ ) } \\
\hline 25.000 & 2,5 & 2,4 & 30,53 & 19,2 & 2,49 & 2,81 \\
\hline 40.000 & 1,6 & 1,7 & 27,28 & 17,7 & 2,49 & 2,80 \\
\hline 55.000 & 1,3 & 1,2 & 21,74 & 16,4 & 2,52 & 2,78 \\
\hline 70.000 & 1,3 & 1,1 & 21,55 & 15,4 & 2,52 & 2,77 \\
\hline C.V.(\%) & 16,6 & 12,8 & 8,4 & 4,6 & 6,1 & 3,4 \\
\hline \multicolumn{7}{|l|}{ Teste F } \\
\hline Espaçamento (E) & $0,29 \mathrm{~ns}$ & $6,722 *$ & $16,38 * *$ & $15,77 * *$ & $0,36 \mathrm{~ns}$ & $1,09 \mathrm{~ns}$ \\
\hline \multicolumn{7}{|l|}{ População inicial (P) } \\
\hline Reg. Linear & $155,53 * *$ & $377,92 * *$ & $187,00 * *$ & $210,38 * *$ & $0,50 \mathrm{~ns}$ & $1,52 \mathrm{~ns}$ \\
\hline Reg. Quadrática & $47,17 * *$ & $1,44 \mathrm{~ns}$ & $8,33 * *$ & $1,44 \mathrm{~ns}$ & $0,00 \mathrm{~ns}$ & $0,00 \mathrm{~ns}$ \\
\hline Ex P & $1,02 \mathrm{~ns}$ & $12,49 * *$ & $5,35 * *$ & $12,49 * *$ & $1,70 \mathrm{~ns}$ & $1,23 \mathrm{~ns}$ \\
\hline
\end{tabular}


A quantidade de racemos produzidos por planta diminuiu significativamente, em ambas as safrinhas, com o aumento da população de plantas, independente do espaçamento entre fileiras (Figura 33). No desdobramento do espaçamento dentro da população de plantas, observa-se que, na população de 25.000 plantas $\mathrm{ha}^{-1}$, o espaçamento de 0,45 m entre fileiras proporcionou o maior número de racemos por planta (Figura 33B), provavelmente, pela melhor configuração espacial $(0,45 \times 0,89 \mathrm{~m})$ das plantas na área nesse tratamento (Tabela 2). Segundo Vale (2009), o número de racemos tende a diminuir à medida que se aumenta a população de plantas. De acordo com o autor, as plantas com maior espaço, ocupam uma maior área de captação de luz, não apresentando interferência ou competição igual às em menores espaços tendo, portanto, melhor arquitetura produtiva, podendo expressar todo seu potencial, na emissão de um número maior de racemos. Nesse sentido, os resultados desse trabalho corroboram os de Vale (2009).

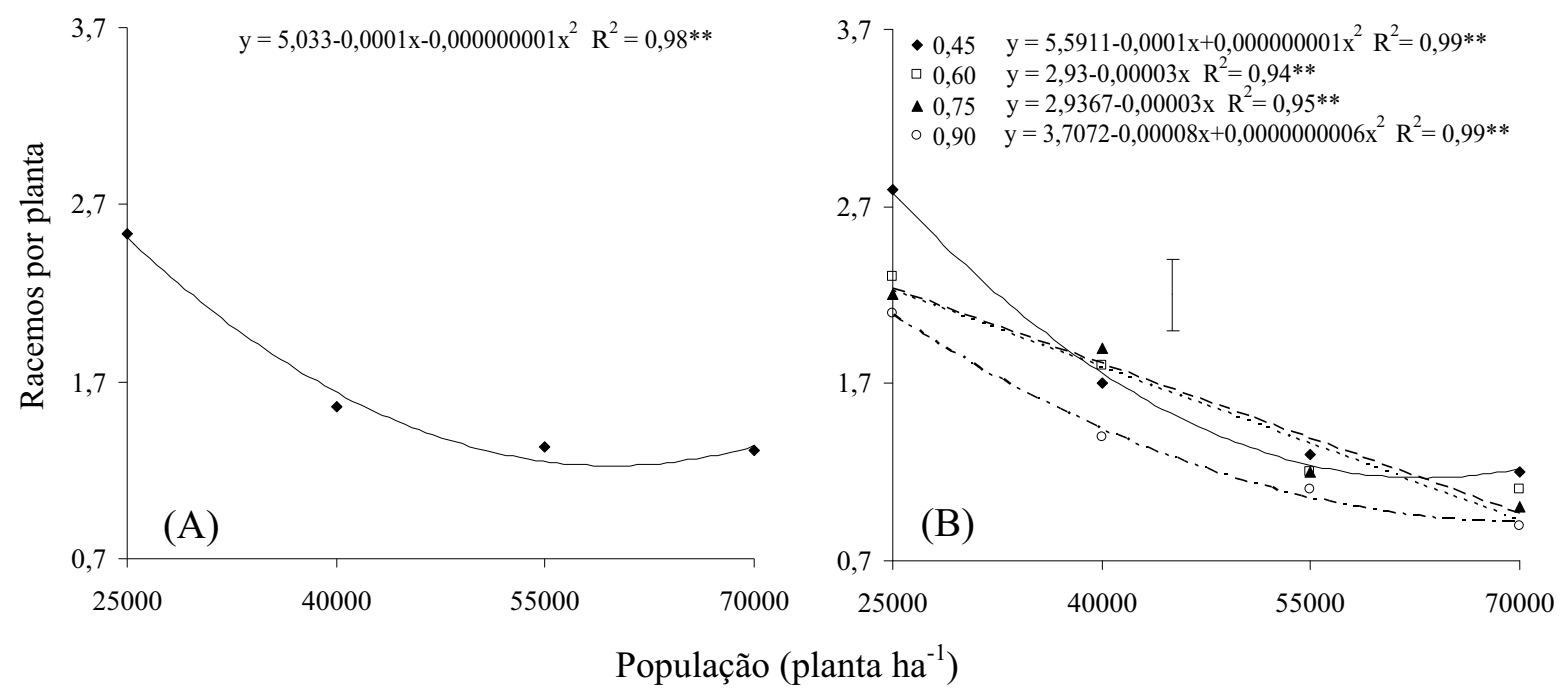

Figura 33. Número de racemos por planta da cultivar de mamona IAC 2028 em função da população de plantas, na média de quatro espaçamentos entre fileiras na safrinha 2008 (A) e cada um dos quatro espaçamentos entre fileiras na safrinha 2009 (B). **é significativo a $1 \%$ de probabilidade pelo teste $\mathrm{F}$. 
O número de frutos por racemo recebeu influência de todos os fatores estudos e por suas interações (Tabela 24 e Figura 34). Na safrinha 2008, o maior número de frutos por racemo foi proporcionado pelos menores espaçamentos $(0,45$ e $0,60 \mathrm{~m})$, com valores médios de 26,5 e 27,0 frutos por racemo, respectivamente, diferindo dos espaçamentos de 0,75 e $0,90 \mathrm{~m}$. Na safrinha 2009 , o espaçamento que propiciou o menor número de frutos por racemo foi o de $0,75 \mathrm{~m}$ entre fileiras, produzindo 16,7 frutos por racemo, diferindo estatisticamente dos espaçamentos de 0,60 e $0,90 \mathrm{~m}$, que apresentaram em média 17,9 frutos por racemo.

Quanto à interação espaçamento x população de plantas, constatou-se que, em ambas as safrinhas, o aumento da população de plantas, em todos os espaçamentos, reduziu o número de frutos por racemo (Figura 34). A redução deste componente da produção ocorreu, provavelmente, devido ao menor crescimento das plantas que se encontravam nessas condições, como pode ser comprovado pelos valores de matéria seca (Figura 29), diâmetro do caule (Figura 30), justificando os resultados obtidos.
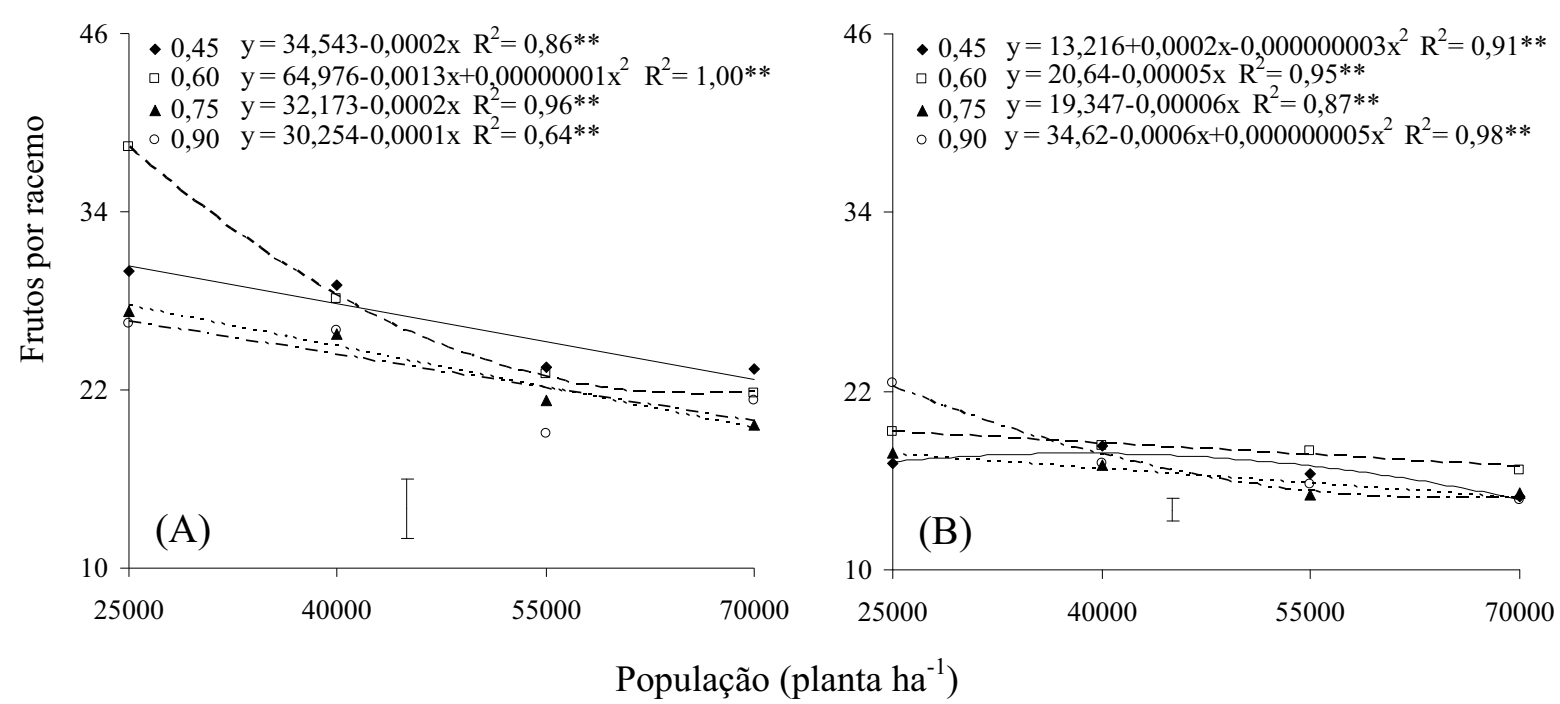

Figura 34. Número de frutos por racemo da cultivar de mamona IAC 2028 em função da população de plantas e do espaçamento entre fileiras nas safrinhas 2008 (A) e 2009 (B). ** é significativo a 1\% de probabilidade pelo teste $\mathrm{F}$. 
Nota-se que o número de grãos por frutos não foi alterado pelos fatores isolados e, tampouco, houve efeito da interação entre eles. Tal comportamento foi constatado tanto na safrinha 2008, quanto na safrinha 2009 (Tabela 24). Conforme já mencionado, este componente da produção é pouco influenciado pelo ambiente, pois é uma característica de alta herdabilidade.

Analisando-se os dados das duas safrinhas, pode-se constatar que a massa de 100 grãos foi influenciada apenas pela população de plantas (Tabela 25), sendo os valores ajustados a equação linear (Figura 35A) e quadrática (Figura 35B).

Tabela 25. Massa de 100 grãos de produtividade de grãos da cultivar de mamona IAC 2028, nas safrinhas 2008 e 2009, em função do espaçamento e população de plantas. Botucatu, SP.

\begin{tabular}{|c|c|c|c|c|}
\hline \multirow{2}{*}{ Fontes de variação } & \multicolumn{2}{|c|}{ Massa de 100 grãos } & \multicolumn{2}{|c|}{ Produtividade de grãos } \\
\hline & 2008 & 2009 & 2008 & 2009 \\
\hline Espaçamento (m) & \multicolumn{2}{|c|}{$(\mathrm{g})$} & \multicolumn{2}{|c|}{$\left(\mathrm{kg} \mathrm{ha}^{-1}\right)^{-}$} \\
\hline 0,45 & $48,5 \mathrm{a}^{(1)}$ & $52,8 \mathrm{a}$ & $2.297 \mathrm{a}$ & $1.780 \mathrm{ab}$ \\
\hline 0,60 & $47,5 \mathrm{a}$ & $54,0 \mathrm{a}$ & $2.430 \mathrm{a}$ & $1.849 \mathrm{a}$ \\
\hline 0,75 & $48,1 \mathrm{a}$ & $55,0 \mathrm{a}$ & $1.991 \mathrm{~b}$ & $1.669 b c$ \\
\hline 0,90 & $48,3 \mathrm{a}$ & $55,2 \mathrm{a}$ & $1.871 \mathrm{~b}$ & $1.537 \mathrm{c}$ \\
\hline C.V.(\%) & 4,2 & 6,2 & 7,2 & 9,0 \\
\hline \multicolumn{5}{|l|}{ População (plantas ha $\left.{ }^{-1}\right)$} \\
\hline 25.000 & 49,3 & 53,5 & 2.375 & 1.687 \\
\hline 40.000 & 48,6 & 55,5 & 2.068 & 1.869 \\
\hline 55.000 & 47,0 & 54,3 & 1.868 & 1.622 \\
\hline 70.000 & 47,4 & 53,7 & 2.278 & 1.658 \\
\hline C.V. $(\%)$ & 3,3 & 3,9 & 10,7 & 8,8 \\
\hline \multicolumn{5}{|l|}{ Teste $\mathrm{F}$} \\
\hline Espaçamento (E) & $0,68 \mathrm{~ns}$ & $1,73 \mathrm{~ns}$ & $45,00 * *$ & $12,46 * *$ \\
\hline \multicolumn{5}{|l|}{ População inicial (P) } \\
\hline Reg. Linear & $16,50 * *$ & $0,06 \mathrm{~ns}$ & $3,64 \mathrm{~ns}$ & $3,93 \mathrm{~ns}$ \\
\hline Reg. Quadrática & $1,64 \mathrm{~ns}$ & $5,58^{*}$ & $39,05 * *$ & $3,69 \mathrm{~ns}$ \\
\hline Ex P & $1,86 \mathrm{~ns}$ & $0,91 \mathrm{~ns}$ & $2,95 * *$ & $6,39 * *$ \\
\hline
\end{tabular}


Vários autores investigando os efeitos da população de plantas na cultura do milho, também encontraram redução dessa variável com o incremento da densidade de plantio (STRIEDER et al., 2007; CARVALHO, 2007; FURTADO, 2005; PALHARES, 2003). Para Sangoi (2000), o decréscimo da massa de 100 grãos possivelmente está associado ao aumento da competição intra-específica provocada pelo aumento da população de plantas. Isso pode ser agravado nas situações de desuniformidade de desenvolvimento das plantas, onde as "plantas dominadas" são mais afetadas pelo aumento da população de plantas, demonstrando que os efeitos da competição intra-específica acontecem tanto quando as plantas estão em maior população ou quando são dominadas por plantas vizinhas que emergiram mais rapidamente (ZANIN, 2007; MEROTTO JUNIOR et al., 1999). É importante ressaltar que as melhores condições de climáticas ocorrida na safrinha 2009 proporcionaram maiores valores médios de massa de 100 grãos, quando comparadas com a safrinha 2008.
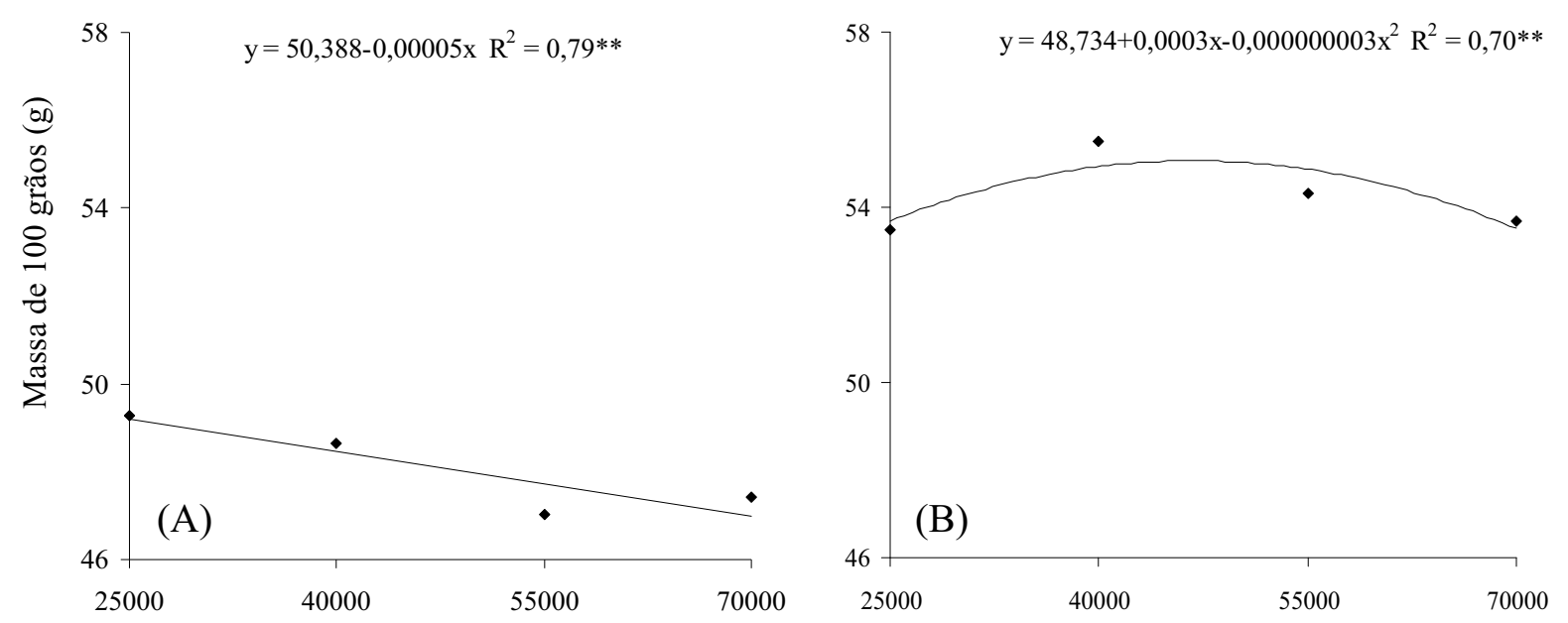

População (planta ha ${ }^{-1}$ )

Figura 35. Massa de 100 grãos da cultivar de mamona IAC 2028 em função da população de plantas nas safrinhas 2008 (A) e 2009 (B). ** é significativo a 1\% de probabilidade pelo teste $\mathrm{F}$. 
Na safrinha 2008, a produtividade de grãos da cultivar IAC 2028 foi influenciada pelo espaçamento entre fileiras, população de plantas e a interação entre os fatores (Tabela 25 e Figura 36). Já na safrinha 2009, não se verificou efeito da população de plantas.

Em ambos os anos, os menores espaçamentos entre fileiras $(0,45 \mathrm{e}$ $0,60 \mathrm{~m}$ ) proporcionaram as maiores produtividades de grãos. O espaçamento de 0,60 m entre fileiras, tanto na safrinha 2008, quanto na safrinha 2009, proporcionou as maiores produtividade de grãos (2.430 e $\left.1.849 \mathrm{~kg} \mathrm{ha}^{-1}\right)$, respectivamente. Por outro lado, o espaçamento de $0,90 \mathrm{~m}$ apresentou os menores valores dessa variável, com produtividades de grãos de 1.871 e $1.537 \mathrm{~kg} \mathrm{ha}^{-1}$.

Por meio da interação significativa entre espaçamento x população de plantas, constata-se que o aumento da população de planta inferiu na produtividade de grãos, sendo os valores médios ajustados a modelos de regressão quadráticos (Figura 36A). Esse decréscimo na produtividade de grãos nas populações intermediárias (40.000 e 55.000 plantas $\left.\mathrm{ha}^{-1}\right)$ e posterior aumento na população (70.000 plantas $\left.\mathrm{ha}^{-1}\right)$, indicam efeito de compensação pelo maior número de plantas na área, já que os números de racemos por planta e de fruto por racemo diminuíram com o aumento da população. Vale (2009) observou um incremento linear na produtividade de grãos com o aumento da população de plantas e nos menores espaçamentos entre fileiras. No entanto, o autor sugere que outros estudos de otimização do espaçamento deveriam ser realizados, já que as condições edafoclimaticas mudam de acordo com a região, podendo, portanto, maiores espaçamentos obter produtividade superiores as de menor espaçamento. Trabalhando com diferentes populações de plantas de milho ha ${ }^{-1}$, Argenta et al. (2001) verificaram redução dos componentes da produção com o aumento da densidade de plantio, porém, os autores relatam que tais perdas foram compensadas por um maior número de plantas, consequentemente número de espigas por área, pois a produtividade de grãos não foi afetada. Pelos resultados encontrados no presente trabalho, o mesmo raciocínio para a cultura da mamona pode ser verdadeiro, já que a maior população de plantas proporcionou maior produtividade de grãos.

$\mathrm{Na}$ safrinha 2009, o aumento da população de plantas, no espaçamento de $0,90 \mathrm{~m}$ entre fileira, reduziu significativamente a produtividade de grãos (Figura 36B). Já, nos demais espaçamentos, não houve efeito, provavelmente devido à melhor 
distribuição das plantas na área. Para Rocha et al. (1964) a aglomeração de plantas na fileira, em função do aumento do espaçamento, promove menor produtividade de grãos.
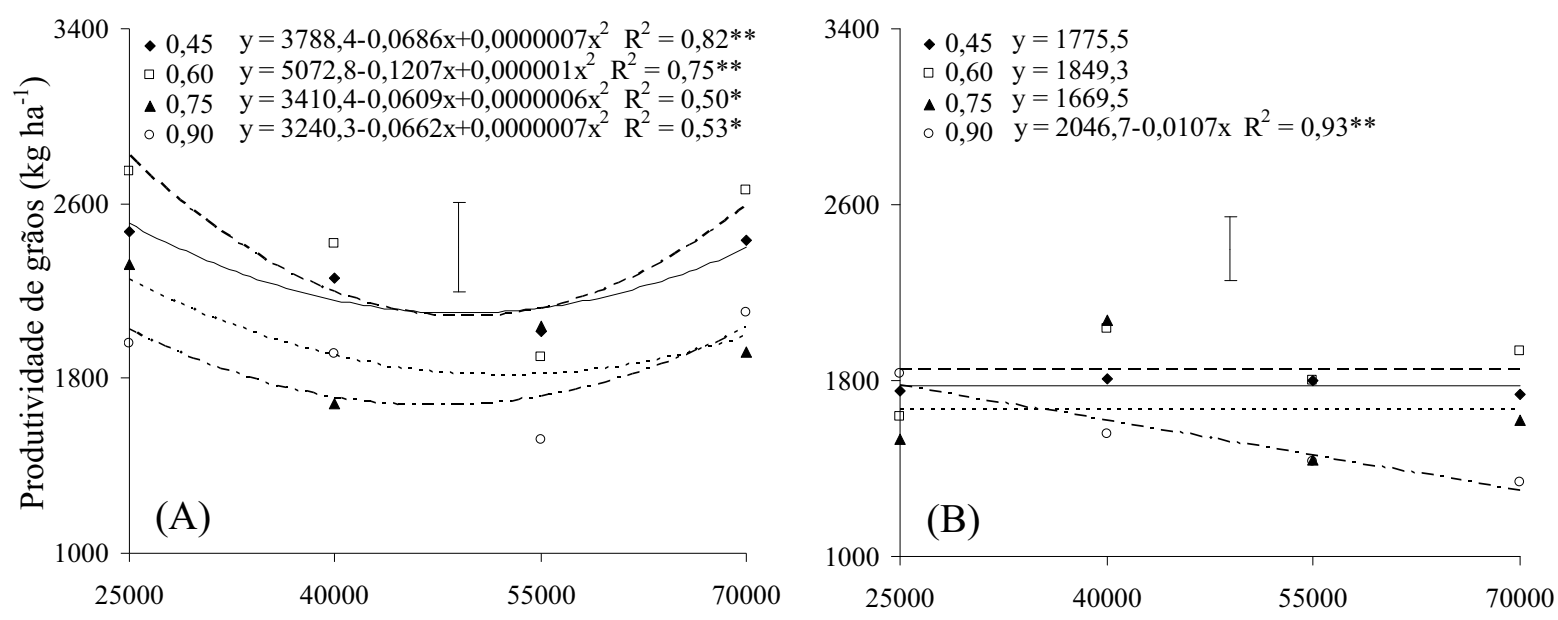

População (planta ha ${ }^{-1}$ )

Figura 36. Produtividade de grãos da cultivar de mamona IAC 2028 em função da população de plantas e do espaçamento entre fileiras nas safrinhas 2008 (A) e 2009 (B). * e ** são significativos a $5 \%$ e $1 \%$ de probabilidade pelo teste $\mathrm{F}$, respectivamente.

O teor de óleo no grão não foi afetado pelos fatores estudados (Tabela 26). Segundo Moshkin (1986) o teor de óleo nos grãos da mamoneira é uma característica que possui alta herdabilidade.

Pode-se observar que o espaçamento entre fileira, a população de plantas e a interação espaçamento x população de plantas influenciaram na produtividade de óleo, nos dois anos de experimentação (Tabela 26). Constata-se que, na safrinha 2008, as maiores produtividades de óleo foram proporcionados pelos espaçamentos de 0,45 e 0,60 m entre fileiras, com 1.029 e $984 \mathrm{~kg} \mathrm{ha}^{-1}$, respectivamente, diferindo dos demais $(0,75 \mathrm{e} 0,90 \mathrm{~m})$. Efeito semelhante proporcionado pelo espaçamento, também foi observado na safrinha 2009. Isso se explica devido as produtividade grãos alcançada nos devidos espaçamentos, visto que essa variável tem uma relação direta com a produtividade de grãos, já que o teor de óleo nos grãos não foi alterado. 
Tabela 26. Teor de óleo no grão e produtividade de óleo da cultivar de mamona IAC 2028, nas safrinhas 2008 e 2009, em função do espaçamento e população de plantas. Botucatu, SP.

\begin{tabular}{|c|c|c|c|c|}
\hline \multirow{2}{*}{ Fontes de variação } & \multicolumn{2}{|c|}{ Teor de óleo no grão } & \multicolumn{2}{|c|}{ Produtividade de óleo } \\
\hline & 2008 & 2009 & 2008 & 2009 \\
\hline Espaçamento (m) & \multicolumn{2}{|c|}{$(\%)$} & \multicolumn{2}{|c|}{$\left(\mathrm{kg} \mathrm{ha}^{-1}\right)^{-}$} \\
\hline 0,45 & $49,2 \mathrm{a}^{(1)}$ & $47,4 \mathrm{a}$ & $984 a$ & $735 \mathrm{ab}$ \\
\hline 0,60 & $48,7 \mathrm{a}$ & $48,5 \mathrm{a}$ & $1.029 \mathrm{a}$ & $781 \mathrm{a}$ \\
\hline 0,75 & $48,0 \mathrm{a}$ & $46,7 \mathrm{a}$ & $833 b$ & $681 b c$ \\
\hline 0,90 & $48,3 \mathrm{a}$ & $45,9 \mathrm{a}$ & $787 b$ & $614 \mathrm{c}$ \\
\hline C.V.(\%) & 5,0 & 5,9 & 10,8 & 9,7 \\
\hline \multicolumn{5}{|l|}{ População (plantas ha ${ }^{-1}$ ) } \\
\hline 25.000 & 49,2 & 45,6 & 1.015 & 671 \\
\hline 40.000 & 48,4 & 47,5 & 873 & 774 \\
\hline 55.000 & 48,2 & 47,7 & 784 & 674 \\
\hline 70.000 & 48,4 & 47,8 & 960 & 692 \\
\hline C.V. $(\%)$ & 2,7 & 6,8 & 11,4 & 10,4 \\
\hline \multicolumn{5}{|l|}{ Teste F } \\
\hline Espaçamento (E) & $0,85 \mathrm{~ns}$ & $1,81 \mathrm{~ns}$ & $22,47 * *$ & $17,82 * *$ \\
\hline \multicolumn{5}{|l|}{ População inicial (P) } \\
\hline Reg. Linear & $3,31 \mathrm{~ns}$ & $3,83 \mathrm{~ns}$ & $4,39 \mathrm{~ns}$ & $0,19 \mathrm{~ns}$ \\
\hline Reg. Quadrática & $1,91 \mathrm{~ns}$ & $2,51 \mathrm{~ns}$ & $38,00 * *$ & $5,45 \mathrm{~ns}$ \\
\hline $\mathrm{E} \times \mathrm{P}$ & $0,59 \mathrm{~ns}$ & $0,83 \mathrm{~ns}$ & $2,71 *$ & $6,10^{* *}$ \\
\hline
\end{tabular}

$\mathrm{Na}$ a interação ente os fatores estudados, verifica-se que o aumento da população de plantas afetou significativamente a produtividade de óleo, com os dados sendo ajustados à função quadrática para todos os espaçamentos, na safrinha 2008 (Figura 38A). Os efeitos observados na produtividade de óleo foram muito semelhantes aos verificados para a produtividade de grãos (Figuras 36Ae 37A). Na safrinha 2009, a produtividade de óleo foi alterada pela população de plantas somente nos espaçamentos de 0,60 e 0,90 m entre fileiras, sendo os dados ajustados a funções quadrática e linear, respectivamente. A maior produtividade foi constatada no espaçamento de $0,60 \mathrm{~m}$, na população calculada de 48.000 
plantas $\mathrm{ha}^{-1}$ (Figura 37B). Já, no espaçamento entre fileiras de $0,90 \mathrm{~m}$, o incremento na população de plantas reduziu significativamente a produtividade de óleo, refletindo o observado para a variável produtividade de grãos (Figuras 36B e 37B).
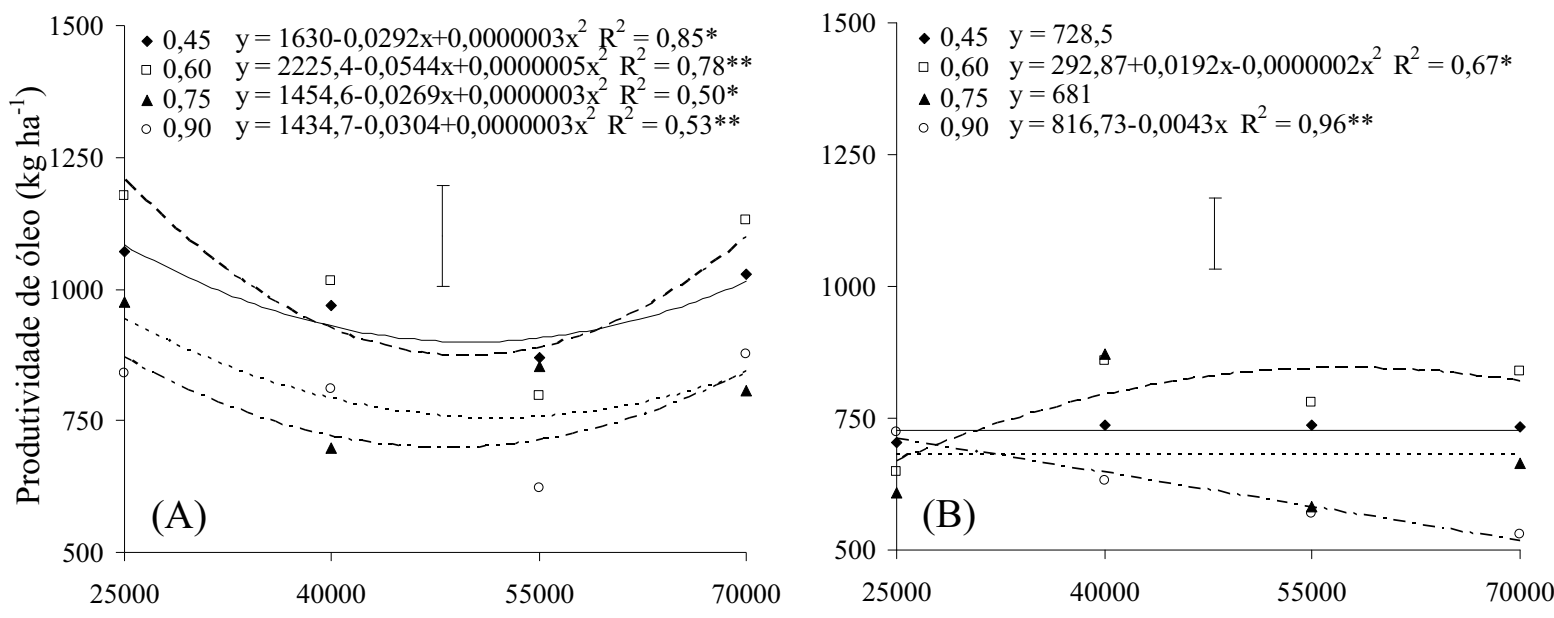

População (planta ha ${ }^{-1}$ )

Figura 37. Produtividade de óleo da cultivar de mamona IAC 2028 em função da população de plantas e do espaçamento entre fileiras nas safrinhas 2008 (A) e 2009 (B). * e ** são significativos a $5 \%$ e $1 \%$ de probabilidade pelo teste $\mathrm{F}$, respectivamente. 


\section{CONCLUSÕES}

\subsection{Experimento da safra de verão (2007/08 e 2008/09)}

\subsubsection{Cultivar FCA-PB}

O aumento da população de plantas, independente do espaçamento entre fileiras, diminuiu a população final de plantas, a matéria seca da parte aérea, o diâmetro do caule, o número de racemos por planta e de frutos por racemo.

O aumento da população de plantas, nos espaçamentos de 0,60 e 0,75 $\mathrm{m}$ entre fileiras, aumentou a altura de inserção do primeiro racemo.

A maior produtividade de grãos e de óleo da mamoneira FCA-PB foi

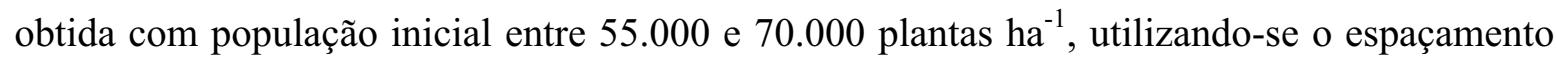
de 0,45 ou 0,60 m entre fileiras.

\subsubsection{Cultivar IAC 2028}

O aumento da população de plantas diminuiu a população final de plantas, a matéria seca da parte aérea, o diâmetro do caule, número de racemos por planta, número de frutos por racemo, massa de 100 grãos e aumentou a altura das plantas e a altura de inserção do primeiro racemo da mamoneira cultivar IAC 2028, independentemente do espaçamento utilizado. 
Em menores espaçamentos entre fileiras e menores populações de plantas, a mamoneira produziu maior número de racemos por planta e menor número de grãos por fruto.

O melhor arranjo de plantas, proporcionado pelos menores espaçamentos entre fileiras, proporcionou as maiores produtividades de grãos e de óleo da cultivar IAC 2028.

A população de plantas, independentemente do espaçamento entre fileiras, teve pouco efeito na produtividade de grãos e óleo.

\subsection{Experimento safrinha (2008 e 2009)}

\subsubsection{Cultivar FCA-PB}

O maior espaçamento entre fileiras $(0,90 \mathrm{~m})$ proporcionou menor crescimento das plantas e produtividade de grãos e óleo da cultivar FCA-PB na safrinha.

As maiores produtividade de grãos e de óleo foram obtidas com o espaçamento de $0,75 \mathrm{~m}$ entre fileiras e populações intermediárias.

\subsubsection{Cultivar IAC 2028}

Os maiores espaçamentos entre fileiras proporcionaram o menor crescimento das plantas, número de racemos por planta, número de frutos por racemo, produtividade de grãos e produtividade de óleo da cultivar IAC 2028 na safrinha.

As maiores populações de plantas proporcionaram menores valores de matéria seca da parte aérea, diâmetro do caule, componentes da produção e, maiores altura de inserção do primeiro racemo da cultivar IAC 2028 na safrinha.

$\mathrm{O}$ espaçamento entre fileiras de $0,60 \mathrm{~m}$ proporcionou as maiores produtividade de grãos da cultivar IAC na safrinha, independentemente da população de plantas. 


\section{REFERÊNCIAS BIBLIOGRÁFICAS}

ALMEIDA, M. L.; SANGOI, L.; ENDER, M. Incremento na densidade de plantas: uma alternativa para aumentar o rendimento de grãos de milho em regiões de curta estação estival de crescimento. Ciência Rural, Santa Maria, v. 30, n. 1, p. 23-29, 2000.

AMORIM NETO, M. da S.; ARAUJO, A. E. de; BELTRÃO, N. E. de. M. Clima e solo. In: AZEVEDO, M. P. de; LIMA, E. F. (Eds.). O agronegócio da mamona no Brasil. Campina Grande: EMBRAPA Algodão, 2001. p. 63-76.

ANDRADE, D.; GALVÃO, J. D.; BRANDÃO, S. S.; GOMES, F. R. Efeito do espaçamento entre fileiras e densidade de plantio sobre a produção do arroz "de sequeiro". Experientiae, Viçosa, v. 11, n. 3, p. 135-161, 1971.

ARGENTA, G.; SILVA, P. R. F.; SANGOI, L. Arranjo de plantas em milho: análise do estado-da-arte. Ciência Rural, Santa Maria, v. 31, n. 6, p. 1075-1084, 2001.

AZEVEDO, D. M. P. de; BELTRÃO, N. E. de M.; SEVERINO, L. S. Manejo cultural. In: AZEVEDO, D. M. P.; BELTRÃO, N. E. de M. (Eds.). O agronegócio da mamona no Brasil. 2. ed. ev. e ampl. Campina Grande: EMBRAPA Algodão, 2007. p. 223-253.

AZEVEDO, D. M. P.; LIMA, E. F.; BATISTA, F. A. S.; LIMA, E. F. V. Recomendações técnicas para o cultivo da mamona (Ricinus communis L.) no Brasil. Campina Grande: Embrapa Algodão, 1997. 52 p. (Embrapa Algodão. Circular Técnica, 25).

BARNI, N. A. Modelos de crescimento, desenvolvimento e rendimento do girassol em função da radiação solar, temperatura e disponibilidade hídrica. 1994. 249 p. Tese (Doutorado em Agronomia) - Faculdade de Agronomia - Universidade Federal do Rio Grande do Sul, Porto Alegre, 1994. 
BELTRÃO, N. E. de M. Informações sobre o Biodiesel, em especial feito com óleo de mamona. Ministério da Agricultura, Pecuária e Abastecimento - Embrapa. Campina Grande. 2003. 3p (EMBRAPA-CNPA. Comunicado Técnico, ISSN 0102-0099).

BEltrão, N. E. de. M.; AZEVEDO, M. P. de. Fitologia. In: AZEVEDO, D. M. P.; BELTRÃO, N. E. de M. (Eds.). O agronegócio da mamona no Brasil. 2. ed. ev. e ampl. Campina Grande: EMBRAPA Algodão, 2007. p. 117-137.

BELTRÃO, N. E. de M.; AZEVEDO, M. P. de.; LIMA, R. de. L. S. de.; QUEIROZ, W. N. de.; QUEIROZ, W. C. de. Ecofisiologia. In: AZEVEDO, D. M. P.; BELTRÃO, N. E. de M. (Eds.). O agronegócio da mamona no Brasil. 2. ed. ev. e ampl. Campina Grande: EMBRAPA Algodão, 2007a, p. 43-72.

BELTRÃO, N. E. de M.; BRANDÃO, Z. N.; AMORIN NETO, M. da S.; AMARAL, J. A. B. do.; ARAúJO, A. E. de. Clima e solo. In: AZEVEDO, D. M. P.; BELTRÃO, N. E. de M. (Eds.). O agronegócio da mamona no Brasil. 2. ed. ev. e ampl. Campina Grande: EMBRAPA Algodão, 2007b, p. 73-93.

CAMPOS, H. Estatística aplicada à experimentação com cana-de-açúcar. São Paulo: FEALQ/USP, 1984. 292p.

CANECCHIO FILHO, V. Resultados de experiências com espaçamento da mamoneira anã, variedade I.A. 38. Bragantia, Campinas, v. 13, n. 25, p. 297-305, 1954.

CANECCHIO FILHO, V.; FREIRE, E. S. Adubação da mamoneira. II - Experiências de espaçamento x adubação. Bragantia, Campinas, v. 18, n.1, p. 77-99, 1959.

CARVALHO, I. Q. Espaçamento entre fileira e população de plantas em milho. 2007. 118 p. Dissertação (Mestrado em Agronomia) - Universidade Estadual de Ponta Grossa, Ponta Grossa, 2007.

CARVAlHO, W. A.; ESPINDOLA, C. R.; PACCOLA, A. A. Levantamento de solos da Fazenda Lageado - Estação experimental "Presidente Médici". Boletim Científico da Faculdade de Ciências Agronômicas, UNESP (Botucatu), n. 1, p. 1-95, 1983.

CHIERICE, G. O.; CLARO NETO, S. Aplicação industrial do óleo. In: AZEVEDO, D. M. P.; BELTRÃO, N. E. de M. (Eds.). O agronegócio da mamona no Brasil. 2. ed. ev. e ampl. Campina Grande: EMBRAPA Algodão, 2007, p. 417-447.

CONAB- Companhia Nacional de Abastecimento (Brasília, DF). Safra 1976/77 a 2007/08: série histórica. Disponível em : $<$ http://www.conab.gorv.br/conabweb/download/safra/MamonaSerieHist.xls> Acesso em: 11 dez. 2009. 
D'YAKOV, A. B. Properties of photosynthesis. In: MOSHKIN, V. A. (Ed.) Castor. New Delhi: Amerind, 1986, p. 65-68.

EMBRATER. Manual técnico do milho: regiões Sul, Sudeste e Centro-Oeste. Brasília, 1979. $260 \mathrm{p}$.

EMPRESA BRASILEIRA DE PESQUISA AGROPECUÁRIA. Sistema Brasileiro de Classificação dos Solos. Rio de Janeiro: EMBRAPA/CNPSO, 1999. 412 p.

FEIRE, E. C.; LIMA, E. F.; ANDRADE, F. P. de; MILANI, M.; NÓBREGA, M. B. de M. Melhoramento genético. In: AZEVEDO, D. M. P.; BELTRÃO, N. E. de M. (Eds.). O agronegócio da mamona no Brasil. 2. ed. ev. e ampl. Campina Grande: EMBRAPA Algodão, 2007, p. 169-194.

FERREIRA, G. B.; VASCONCELOS, O. L.; PEDROSA, M. B.; ALENCAR, A. R.; FERREIRA, A. F.; FERNANDES, A. L. P. Produtividade da mamona híbrida savana em diversas populações de plantio no sudoeste da Bahia. In: II CONGRESSO BRASILEIRO DE MAMONA, 2., 2006, Aracajú. Cenário atual e Perspectiva... Campina Grande: Embrapa Algodão, 2006. 1 CD-ROM.

FURTADO. M. B. F. Sistemas de preparo do solo e populações de plantas em espaçamentos reduzidos: comportamento de cultivares de milho (Zea mays L.). $2005.87 \mathrm{f}$. Dissertação (Mestrado em Agronomia/Agricultura) - Faculdade de Ciências Agronômicas, Universidade Estadual Paulista, Botucatu, 2005.

GALLAGHER, J. N.; BISCOE, P. V. Radiation absorption, growth and yield of cereals. Journal of Agricultural Science, Cambridge, v. 91, n. 1, p. 47-60, 1978.

GONDIM, T. M. de S.; VASCONCELOS, R. A. SEVERINO, L. S.; MILANI, M.; NÓBREGA, M. B. de M.; Adensamento de mamoneira em condições de sequeiro em missão velha, CE. In: II CONGRESSO BRASILEIRO DE MAMONA, 2., 2006, Aracajú. Cenário atual e Perspectiva: anais... Campina Grande: Embrapa Algodão, 2006. 1 CD-ROM.

HERMELY, F. X. Mamona: comportamento e tendências no Brasil. Brasília: EMBRAPADID, 1981. 69 p. (EMBRAPA-DTC, Documentos, 2).

HOLANDA, A. Biodiesel e inclusão social. Brasília: Câmara dos Deputados, Coordenação de publicações, 2004. 200 p.

HOLLIDAY, R. Plant population and crop yield. Field Crop Abstracts, Wallingford, v. 13, n. 3, p. 159-167, 1960. 
JOHNSON, G. A.; HOVERSTAD, T. R.; GREENWALD, R. E. Integrated weed management using narrow corn row spacing, herbicides, and cultivation. Agronomy Journal, Madison, v. 90, n. 1, p. 40-46, 1998.

KASPERBAUER, M. J.; KARLEN, D. L. Plant spacing and reflected far-red light effects on phytochrome-regulated photosynthate allocation in corn seedlings. Crop Science, Madison, v. 34, n. 6, p. 1564-1569, 1994.

KITTOCK, D. L.; WILLIAMS, J. H. Effects of plant population on castorbean yield. Agronomy Journal, Madison, v. 62, p. 527-529, 1970.

LOMBARDI NETO, F.; DRUGOWICH, M. I. Manual técnico de manejo e conservação de solo e água. Campinas: CATI, 1994. v. 2, 168 p.

LOOMIS, R. S.; AMTHOR, J. S. Yield potential, plant assimilatory capacity, and metabolic efficiencies. Crop Science, Madison, v. 39, n. 6, p. 1584-1596, 1999.

LOOMIS, R. S.; CONNORS, D. J. Crop ecology: productivity and management in agricultural systems. Cambridge: Cambridge University, 1992. 550 p.

MELGES, E.; LOPES, N. F.; OLIVA, M. A. Crescimento, produção de matéria seca e produtividade da soja submetida a quatro níveis de radiação solar. Pesquisa Agropecuária Brasileira, Brasília, v. 9, n. 6, p. 1073-1080, 1989.

MEROTTO JUNIOR, A.; SANGOI, L.; ENDER, M.; GUIDOLIN, A. F.; HAVERROTH, H. S. Desuniformidade de emergência reduz o rendimento de grãos de milho. Ciência Rural, Santa Maria, v. 29, n. 4, p. 595-601, 1999.

MILANI, M.; MIGUEL JR., S. R.; OLIVEIRA, E. C. S. de.; NÓBREGA, M. B. de M.; COSTA, M. N. da. Caracterização taxonômica de acessos de mamona (Ricinus communis L.) do banco ativo de germoplasma da Embrapa Algodão. Campina Grande: EMBRAPACNPA, 2006. 18 p. (EMBRAPA - CNPA, Boletim de Pesquisa e Desenvolvimento, 67).

MOLIN, R. Espaçamento entre linhas de semeadura na cultura de milho. Castro, Fundação ABC para Assistência e Divulgação Técnica Agropecuária, 2000. p.1-2.

MOREIRA, J. A. N.; LIMA, E. F.; FARIAS, F. J. C.; AZEVEDO, D. M. P. de. Melhoramento da mamoneira (Ricinus communis L.) Campina Grande. EMBRAPA-CNPA, 1996. 29 p. (EMBRAPA-CNPA. Documentos, 44).

MOSHKIN, V. A. Growth and development of the plant. In: MOSHKIN, V.A. (Ed.). Castor. New Delhi: Amerind, 1986. p. 36-42. 
MOSHKIN, V. A.; PERESTOVA, T. A. Morphology and anatomy. In: MOSHKIN, V.A. (Ed.). Castor. New Delhi: Amerind, 1986. p. 28-33.

MUNDSTOCK, C. M. Densidade de semeadura no milho para o Rio Grande do Sul. Porto Alegre : UFRGS/ASCAR, 1977. 35 p.

PALHARES, M. Distribuição e população de plantas e produtividade de grãos de milho. 2003. 90 f. Dissertação (Mestrado em Agronomia/Fitotecnia) - Escola Superior de Agricultura Luiz de Queiroz, Universidade de São Paulo, Piracicaba, 2003.

PASSSAMAI, J. M.; SOUZA, C. M. de.; GALVÃO, C. C. Sistema de preparo do solo para o cultivo de milho safrinha. Bragantia, Campinas, v. 60, n. 2, p. 79-82, 2001.

PEREIRA, R. S. B. Caracteres correlacionados com a produção e suas alterações no melhoramento genético do milho (Zea mays L.). Pesquisa Agropecuária Brasileira, Brasília, v. 26, p. 745-751, 1991.

RAIJ, B. van; QUAGGIO, J. A. Métodos de análise de solo para fins de fertilidade. Campinas: Instituto Agronômico, 1983. 31 p. (Boletim Técnico, 81).

ROCHA, J. L. V.; CONECCHIO FILHO, V.; FREIRE, E. S.; SCARANARI, H.; PETTINELLI, A. Adubação da mamoneira. IV - Experiências de espaçamento x adubação (2a série). Bragantia, Campinas, v. 23, n. único, p. 257-269, 1964.

SANGOI, L. Understanding plant density effects on maize growth and development: an important issue to maximize grain yield. Ciência Rural, Santa Maria, v. 31, n.1, p. 159-168, 2000.

SANTOS, A. C. M.; FERREIRA, G. B.; XAVIER, R. M.; FERREIRA, M. M. M.; SEVERINO, L. S.; BELTRÃO, N. E. de M.; DANTAS, J. P.; MORAES, C. R. A. Deficiência de nitrogênio na mamona (Ricinus communis 1.): Descrição e efeito sobre o crescimento e a produção. In: I CONGRESSO BRASILEIRO DE MAMONA, 1. 2004, Campina Grande. Energia e Sustentabilidade: anais... Campina Grande, Embrapa Algodão, 2004. 1 CD-ROM.

SAVY FILHO, A. Mamona - Tecnologia agrícola. Campinas: Emopi, 1. ed. 2005. 105 p.

SAVY FILHO, A. Mamona. In: RAIJ, B. van; CANTARELA, H.; QUAGGIO, J. A.; FURLANI, A. M. C. Recomendações de adubação e calagem para o Estado de São Paulo. 2. ed. Campinas: Instituto Agronômico e Fundação IAC, 1996. p. 201 (Boletim técnico, 100).

SAVY FILHO, A.; AMORIM, E. P.; RAMOS, N. P.; MARTINS, A. L. M.; CAVICHIOLI, J. C. IAC-2028: nova cultivar de mamona. Pesquisa Agropecuária Brasileira, Brasília, v. 42, n. 3, p. 449-452, 2007. 
SAVY FILHO, A.; BANZATO, N. V. Mamona (Ricinus communis L.). In: JORGE, J. A.; LOURENÇÃO, A. L.; ARANHA, C. Instruções agrícolas para o Estado de são Paulo. 5. ed. Campinas, SP: Instituto Agronômico, 1990. 233 p. (IAC. Boletin, 200).

SAVY FILHO, A.; BANZATO, N. V.; BARBOZA, M. Z.; MIGUEL, A. M. R. O.; DAVI, L. O. C.; RIBEIRO, F. M. Mamona: In: COORDENADORIA DE ASSISTÊNCIA TÉCNICA INTEGRAL. Oleaginosas no estado de São Paulo: análise e diagnóstico. Campinas, 1999. 39 p. (Cati. Documento Técnico, 107).

SEVERINO, L. S.; COELHO, D. K.; MORAES, C. R. A.; GONDIM, T. M. S.; VALE, L. S. do. Otimização do espaçamento de plantio para a mamoneira cultivar BRS Nordestina. Revista Brasileira de Oleaginosas e Fibrosas, Campina Grande, v. 10, n. 1/2, p. 993-999, 2006a.

SEVERINO, L. S.; MORAES, C. R. A.; GONDIM. T. M. S.; CARDOSO, G. D.; BELTRÃO, N. E. de M. Crescimento e produtividade da mamoneira influenciada por plantio em diferentes espaçamentos entre linhas. Revista Ciência Agronômica, Fortaleza, v. 37, n. 1, p. 50-54, $2006 b$.

SILVA, M. I. de LIMA. Acúmulo de fitomassa e componentes de produção da mamoneira em função de desfolhamento e adubação nitrogenada. 2008. 58 p. Dissertação (Mestrado em agronomia) - Centro de Ciências Agrárias, Universidade Federal da Paraíba. Campina Grande, 2008.

SILVA, P. R. F. da. Densidade e arranjo de plantas em milho. In: CONGRESSO NACIONAL DE MILHO E SORGO, 19, 1992, Porto Alegre, RS. Conferências... Porto Alegre: Secretaria da Agricultura - CIENTEC-ABMS, 1992. p. 291-294.

SILVA, S. V.; CHIAVEGATO, E. J.; CARVALHO, L. H.; KUBIAK, D. M. Crescimento e desenvolvimento do algodoeiro em diferentes configurações de semeadura. Bragantia, Campinas, v. 65, n. 3, p. 407-411, 2006.

SOUZA, A. dos S.; TÁVORA, F. J. A. F. Florescimento e produtividade da mamoneira cultivada em diferentes épocas. In: II CONGRESSO BRASILEIRO DE MAMONA, 2., 2006, Aracajú. Cenário atual e Perspectiva: anais... Campina Grande: Embrapa Algodão, 2006. 1 CD-ROM.

STRIEDER, M. L.; SILVA, P. R. F. da.; ARGENTA, G.; RAMBO, L.; SANGOI, L.; SILVA, A. A. da.; ENDRIGO, P. C. A resposta do milho irrigado ao espaçamento entrelinhas depende do híbrido e da densidade de plantas. Ciência Rural, Santa Maria, v. 37, n. 3, p. 634-642, 2007.

TAIZ, L.; ZEIGER, E. Fisiologia vegetal. 3. ed. Porto Alegre: Artmed, 2004. 719 p. 
TÁVORA, T. J. A. A cultura da mamona. Fortaleza: EPACE, 1982. 111 p.

TETIO-KAGHO, F.; GARDNER, F. P. Responses of maize to plant population density. II. Reproductive development, yield and yield adjustments. Agronomy Journal, Madison, v. 80, n. 5, p. 935-940, 1988.

TOLLENAAR, M. Is low plant density a stress in maize? Maydica, Bergamo, v. 37, n. 2, p. 305-311, 1992.

TOLLENAAR, M.; BRUULSEMA, T. W. Efficiency of maize dry matter production during periods of complete leaf area expansion. Agronomy Journal, Madison, v. 80, p. 580-585, 1988.

VALE, L. S. do. Crescimento e produtividade da mamoneira BRS Energia submetida a diversos espaçamentos. 2009. 31p. Dissertação (Mestrado em agronomia) - Centro de Ciências Agrárias, Universidade Federal da Paraíba. Campina Grande, 2009

WEISS, E. A. Castor. In: WEISS, E.A. Oilseed crops. London: Longman, 1983. p. 31-99.

ZANIN, C. G. Senescência foliar lenta e desenvolvimento uniforme como características favoráveis à adaptação de cultivares de milho ao incremento na população de plantas. 2007. 93 p. Dissertação (Mestrado em Produção Vegetal) - Universidade do Estado de Santa Catarina, Lages, 2007. 
102

9 APÊNDICE 

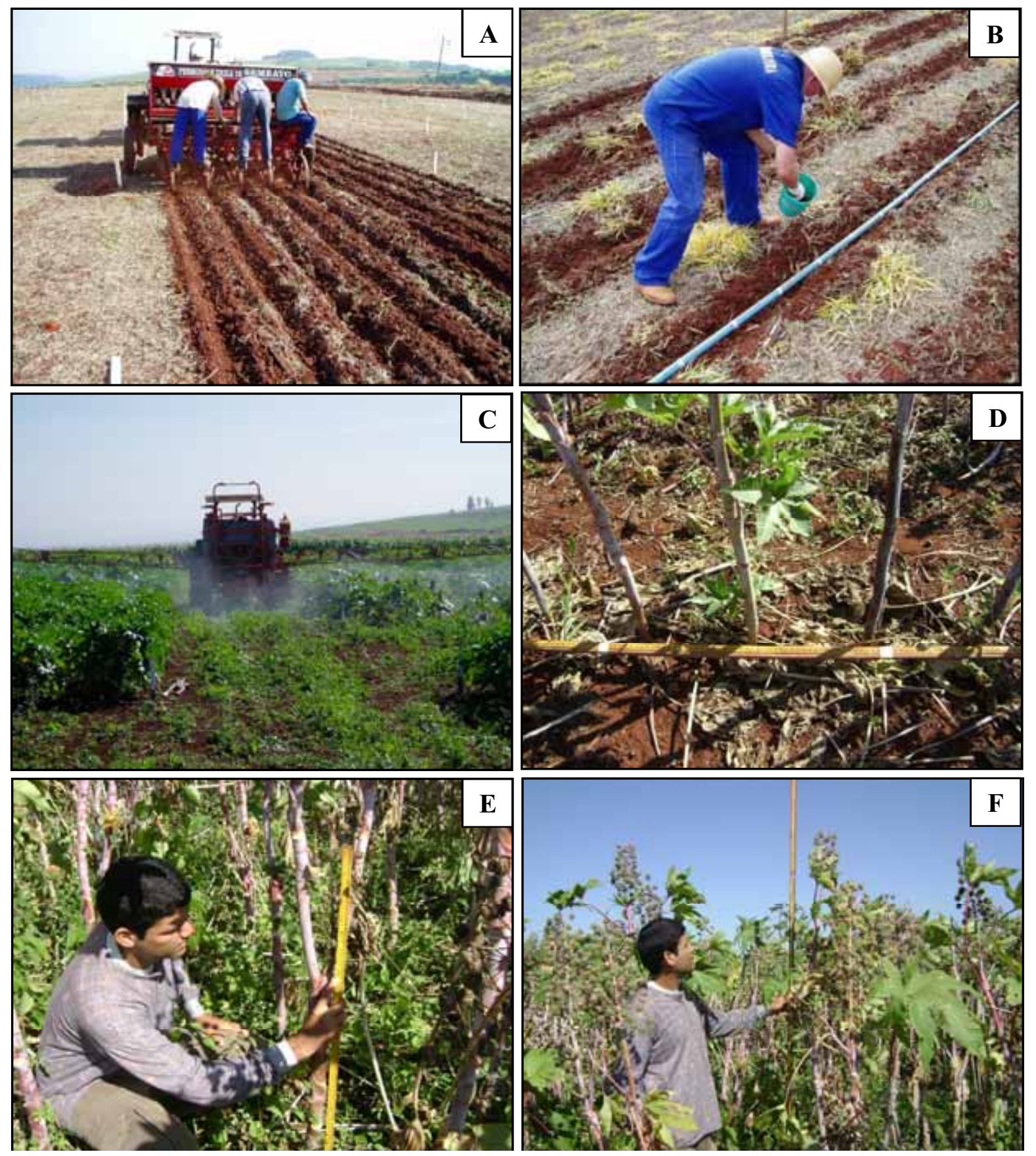

APÊNDICE 1. A- Adubação de base e abertura do sulco de plantio; B- semeadura manual; C- manejo fitossanitário; D- população final de plantas; E- altura de inserção do primeiro racemo; F- altura de planta. Botucatu, SP. 

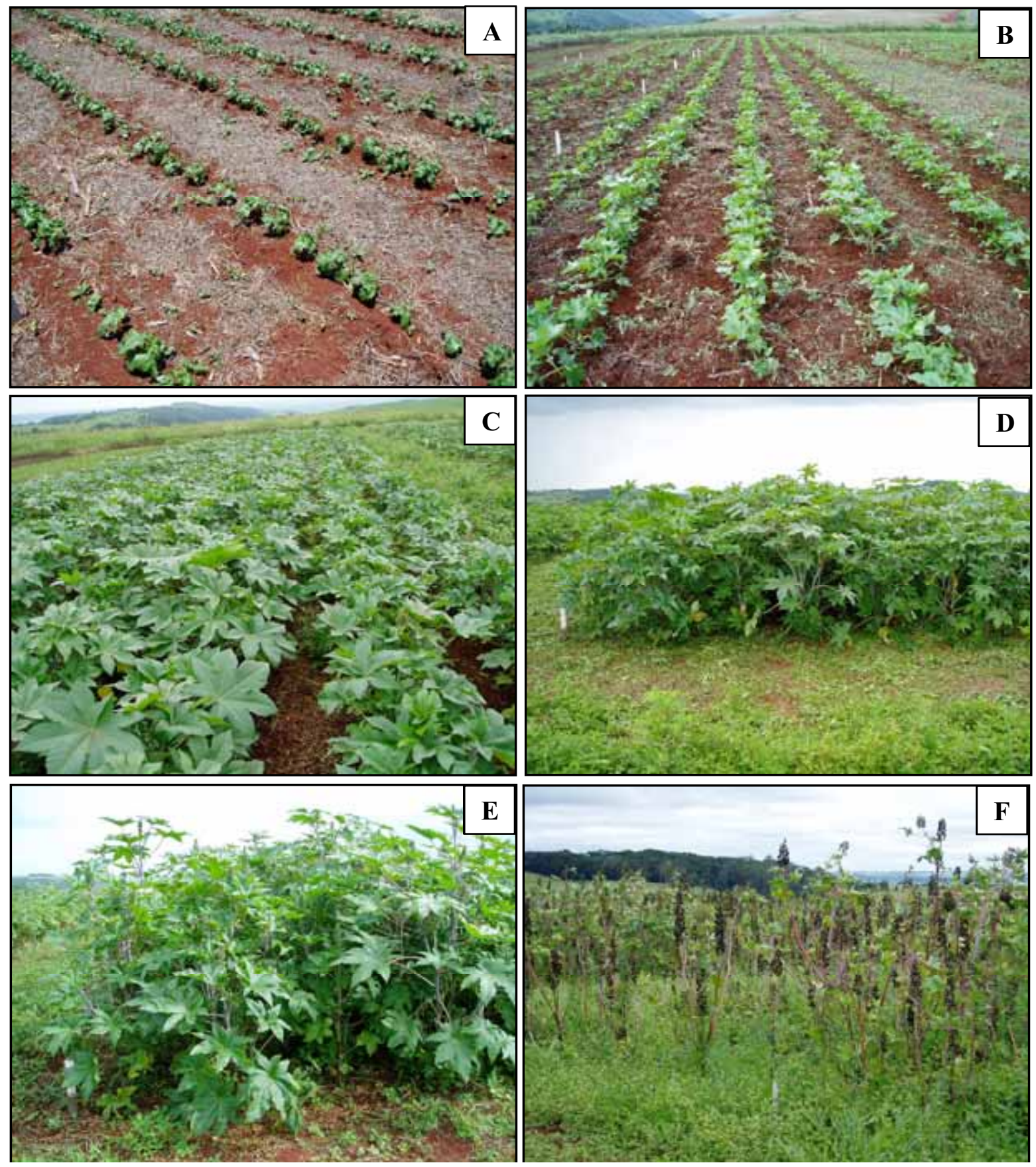

APÊNDICE 2. Cultivar FCA-PB na safra de verão 2007/08. A- 9 DAE; B- 23 DAE; C- 42 DAE; D- 71 DAE; E- 88 DAE; F- 113 DAE. 


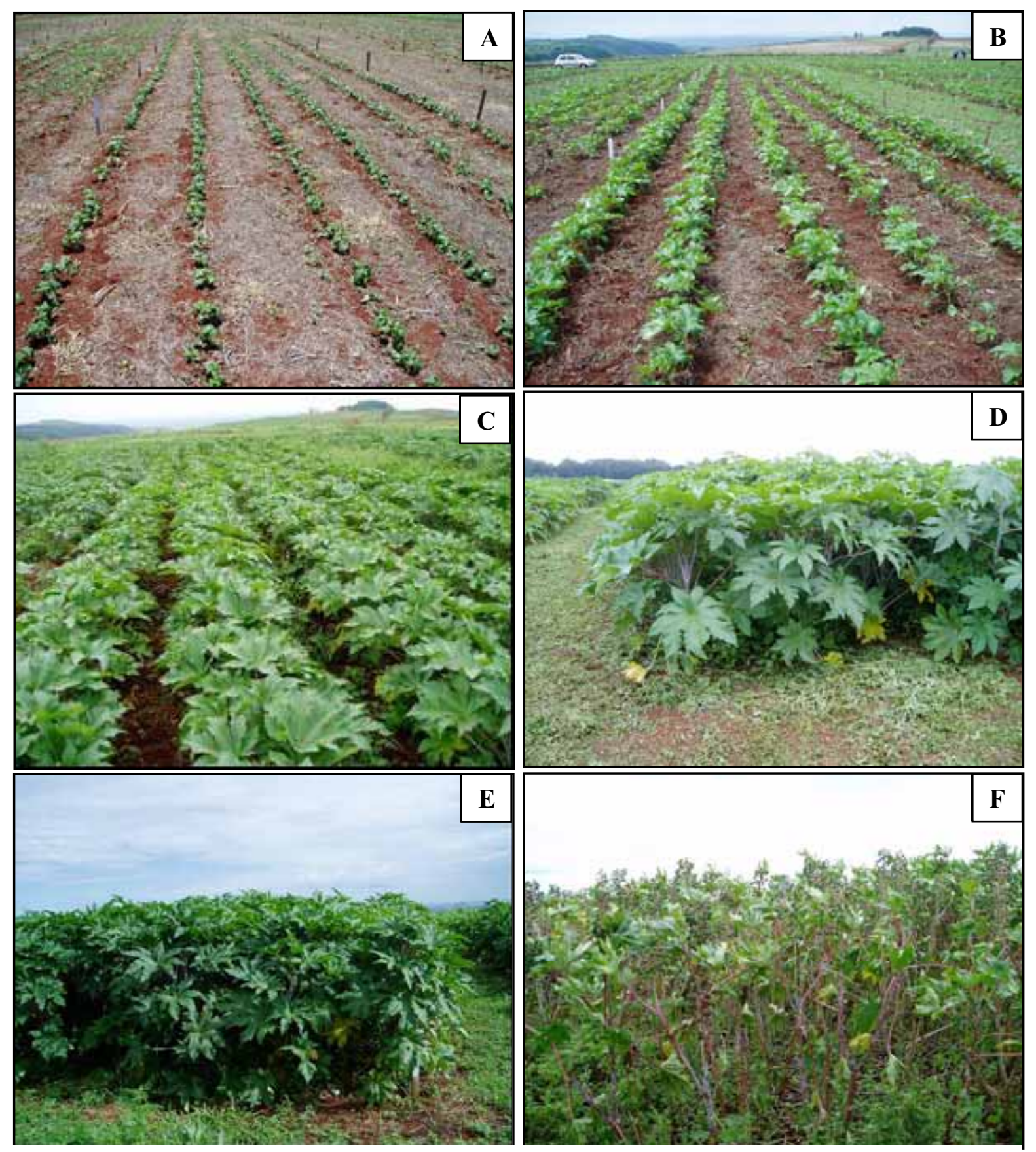

APÊNDICE 3. Cultivar IAC 2028 na safra de verão 2007/08. A- 9 DAE; B- 23 DAE; C- 42 DAE; D- 71 DAE; E- 88 DAE; F- 113 DAE. Botucatu, SP. 

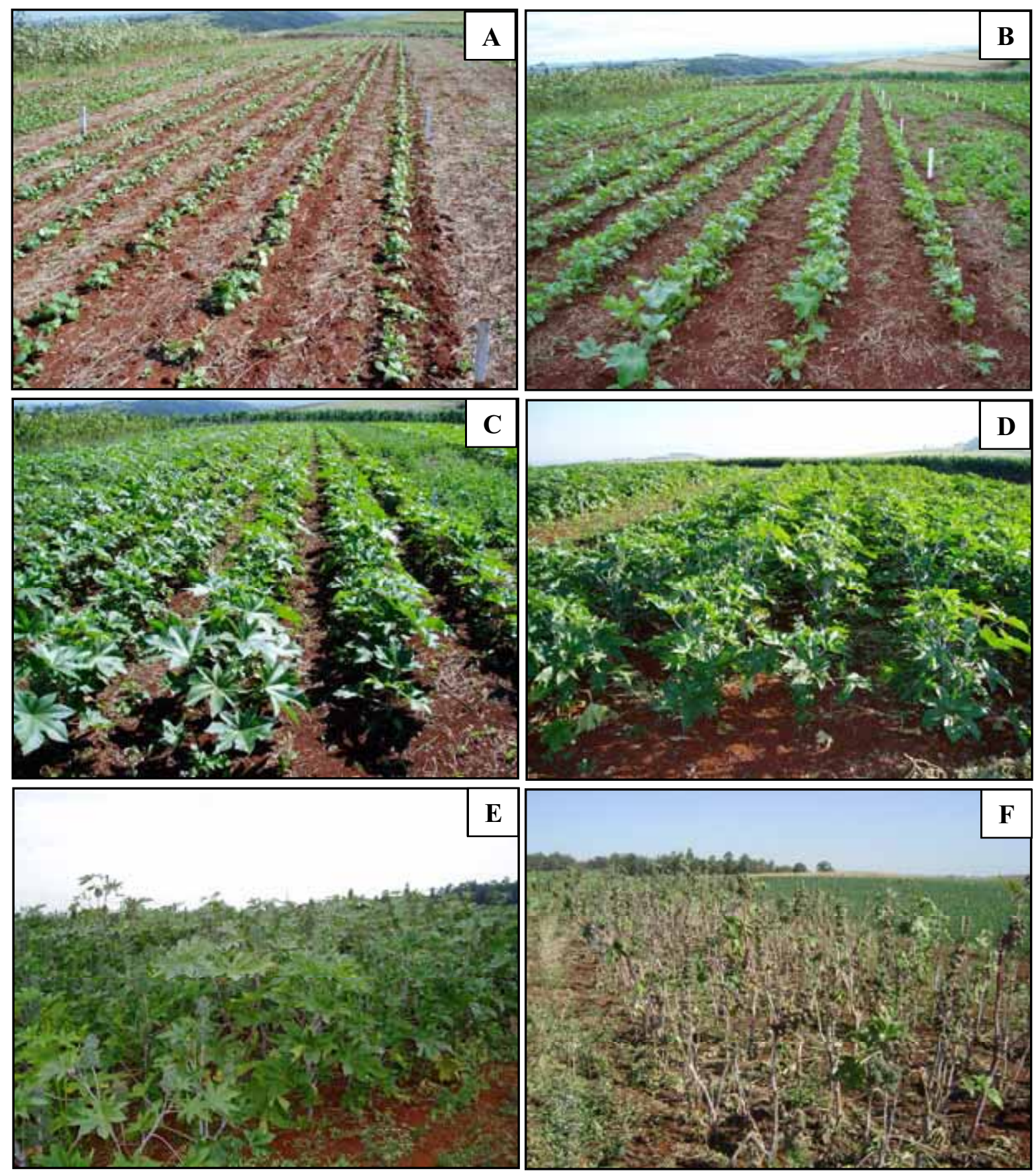

APÊNDICE 4. Cultivar FCA-PB na safrinha 2008. A- 13 DAE; B- 28 DAE; C- 39 DAE; D72 DAE; E- 102 DAE; F- 154 DAE. Botucatu, SP. 

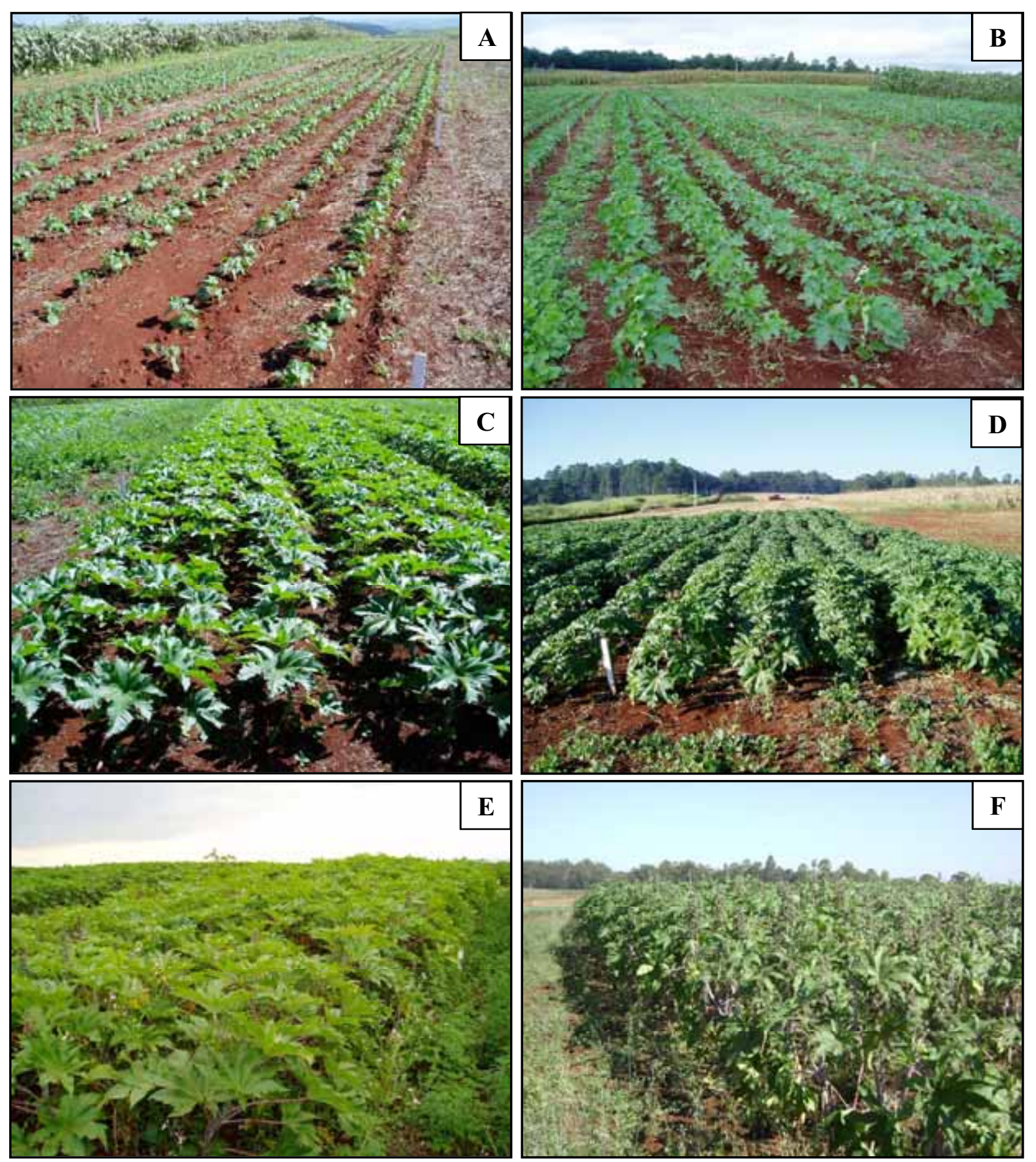

APÊNDICE 5. Cultivar IAC 2028 na safrinha 2008. A- 13 DAE; B- 28 DAE; C- 39 DAE; D72 DAE; E- 102 DAE; F- 154 DAE. Botucatu, SP. 